\title{
Early Cultural Developments on the Eastern Rim of the Tibetan Plateau: Establishing a New Chronological Scheme for the Liangshan Region
}

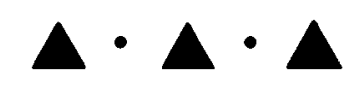

Anke HeIN

\begin{abstract}
Research on the eastern rim of the Tibetan Plateau is generally hampered by the lack of established chronologies. The mountains of southwest China in particular are not very well explored. As a point of intersection of various culture-geographic regions and of long-distance exchange networks, the Liangshan region in southwest Sichuan deserves special attention. Unfortunately, this area is usually excluded from studies into the prehistory of southwest China, chiefly because the archaeological material is remarkably heterogeneous and the local prehistoric cultural sequence therefore has long remained obscure. Based on the results of excavations and survey work conducted during recent decades, this article represents a first attempt to suggest a chronological scheme for southwest China and neighboring parts of Yunnan from the earliest evidence of human occupation around 3000 B.C. to the onset of large-scale Han influence around A.D. 100. Additionally, the article reconstructs processes of early cultural developments and human occupation of the southeastern rim of the Tibetan Plateau that can serve as a point of departure for future research on the prehistory of western China. Keywords: Tibetan Plateau, prehistory, chronology, Sichuan, Yunnan, Liangshan, cultural history.
\end{abstract}

\section{INTRODUCTION}

KnOwledge of the prehistory of Southwest China has long been hampered by a lack of established chronologies and cultural sequences for many of its subregions. While relatively flat regions such as the Chengdu Basin in Sichuan and the area around Lake Dian in Yunnan are well researched (Flad and Chen 2013; Li 1998; Pirazzoli-t'Serstevens 1974; Psarras 2015; Sun 2000; Yao 2008), the mountains on the far eastern rim of the Tibetan Plateau are comparatively under-explored. Located at the intersection of the Qinghai-Tibet and Yunnan-Guizhou Plateaus and bordering the Sichuan Basin, the Liangshan region 涼山 in southwest Sichuan has long been an important transit point between various cultural-geographic regions (Fig. 1). The known archaeological evidence clearly shows that this region has been crucial to connections between the far southwest and northwest China and the Central Plains (Hein 2014a). The local archaeological material is regularly cited as evidence for the

Anke Hein is Associate Professor at the University of Oxford Institute of Archaeology. 


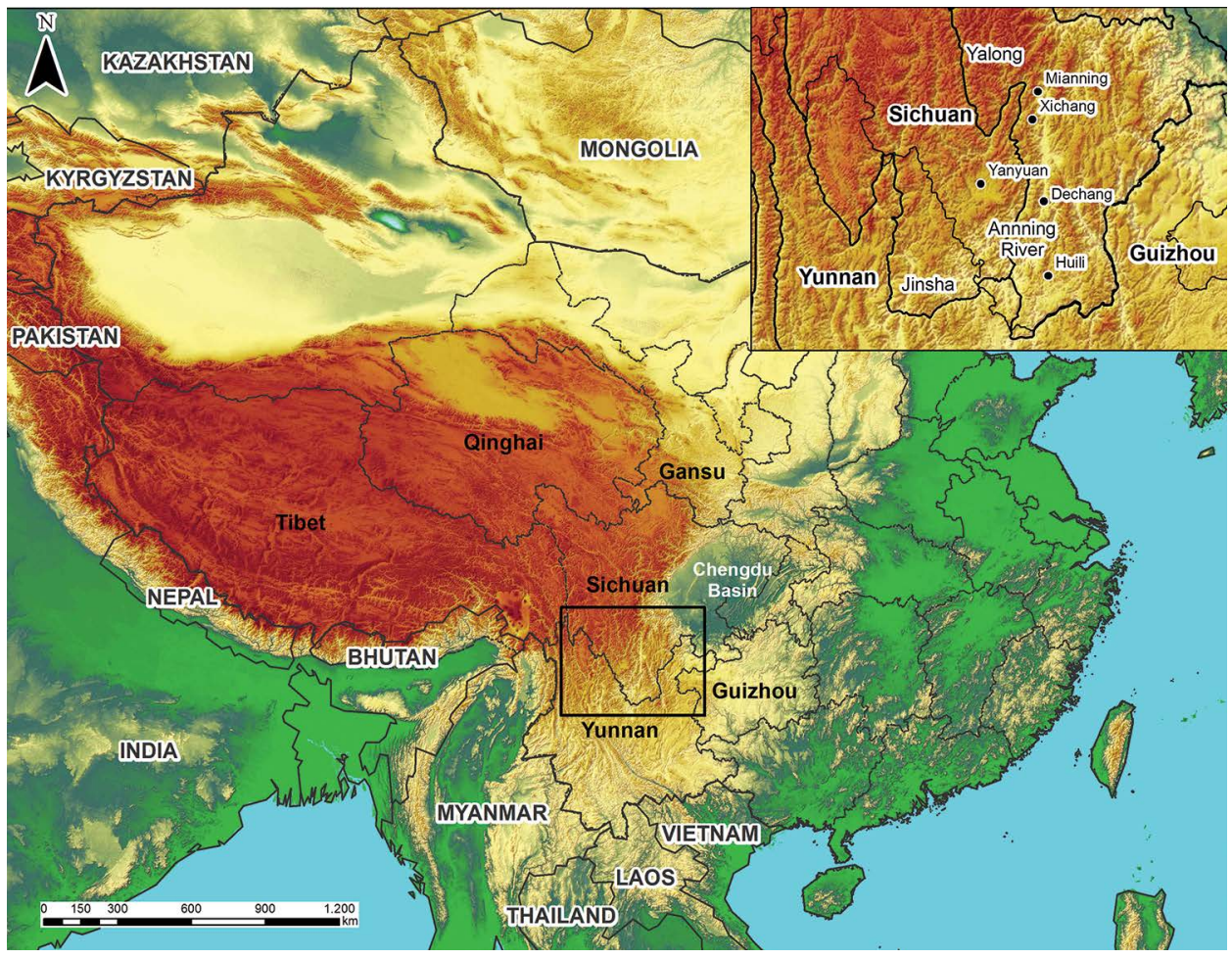

Fig. 1. Geographic location of the research area.

existence of long-distance exchange networks between southwest China and Southeast Asia on the one hand and Central Asia and central China on the other (Hein 2014a, 2014b, 2014c; Liu 2009).

Despite this, the Liangshan region is rarely included in studies of the prehistory of Sichuan or Yunnan. The main explanations for this puzzling omission are that the local archaeological material is quite heterogeneous and the chronological positions of many finds made during the 1980s and 1990s are unclear due to a lack of stratigraphic evidence or radiocarbon dates. Intensification of archaeological work in the Liangshan region since the early 2000s has led to numerous new discoveries that could help resolve the chronological questions and clarify the cultural heterogeneity of the region. Based on this new evidence, this article suggests for the first time a chronological scheme for southwest Sichuan. It also paints a picture of local cultural developments from the earliest evidence of human occupation around 3000 B.C. to the onset of large-scale Han cultural influence around A.D. 100. This new chronology is meant to serve as a reference and point of departure for future research on early human movements on the Tibetan Plateau and neighboring regions of southwest China.

\section{GEOGRAPHIC BACKGROUND}

This study centers on the Liangshan Yi Autonomous Prefecture 涼山䕨族自治州 located in southwest Sichuan and neighboring parts of northwest Yunnan. The 
research area, henceforth referred to as the Liangshan region for short, is circumscribed by the high Shaluli 沙魯里 mountains in the northwest, the Dadu River in the northeast, and the Jinsha River in the south. This well-defined geographic entity of about 81,434 $\mathrm{km}^{2}$ encompasses present-day Liangshan Prefecture and also includes the city of Panzhihua (which consists of Miyi, Yanbian, Renhe, and the very small Xi District and Dong District) and adjacent parts of northwest Yunnan, specifically the counties of Ninglang 寧郎, Huaping 華坪, and Yongsheng 永勝 (Figs. 1, 2). ${ }^{1}$ The region comprises a number of physiogeographic subregions or areas with widely differing characteristics: 1) the Anning River Valley 安寧河流 in the center has a temperate climate; 2) the mountains in the northeast area have a continental climate; 3) the southeastern area has a temperate to subtropical climate; 4) the high-altitude northwestern area has an alpine-steppe climate; and 5) the southwestern high-altitude mountains, plateaus, and valleys have a varied but largely temperate climate (Fig. 2). The climate throughout the Liangshan region has marked dry and wet seasons influenced by the southwest Asian monsoon, with ample annual rainfall distributed unevenly throughout the region. The northwestern area is rather dry, while the northeast suffers from water runoff from the eroded mountains during the monsoon. Average temperatures range between 14 and $18{ }^{\circ} \mathrm{C}$, but temperatures during winter in the north drop to well below freezing, while Panzhihua in the south is dominated by extremely hot summers and warm winters (Chengdu 2010).

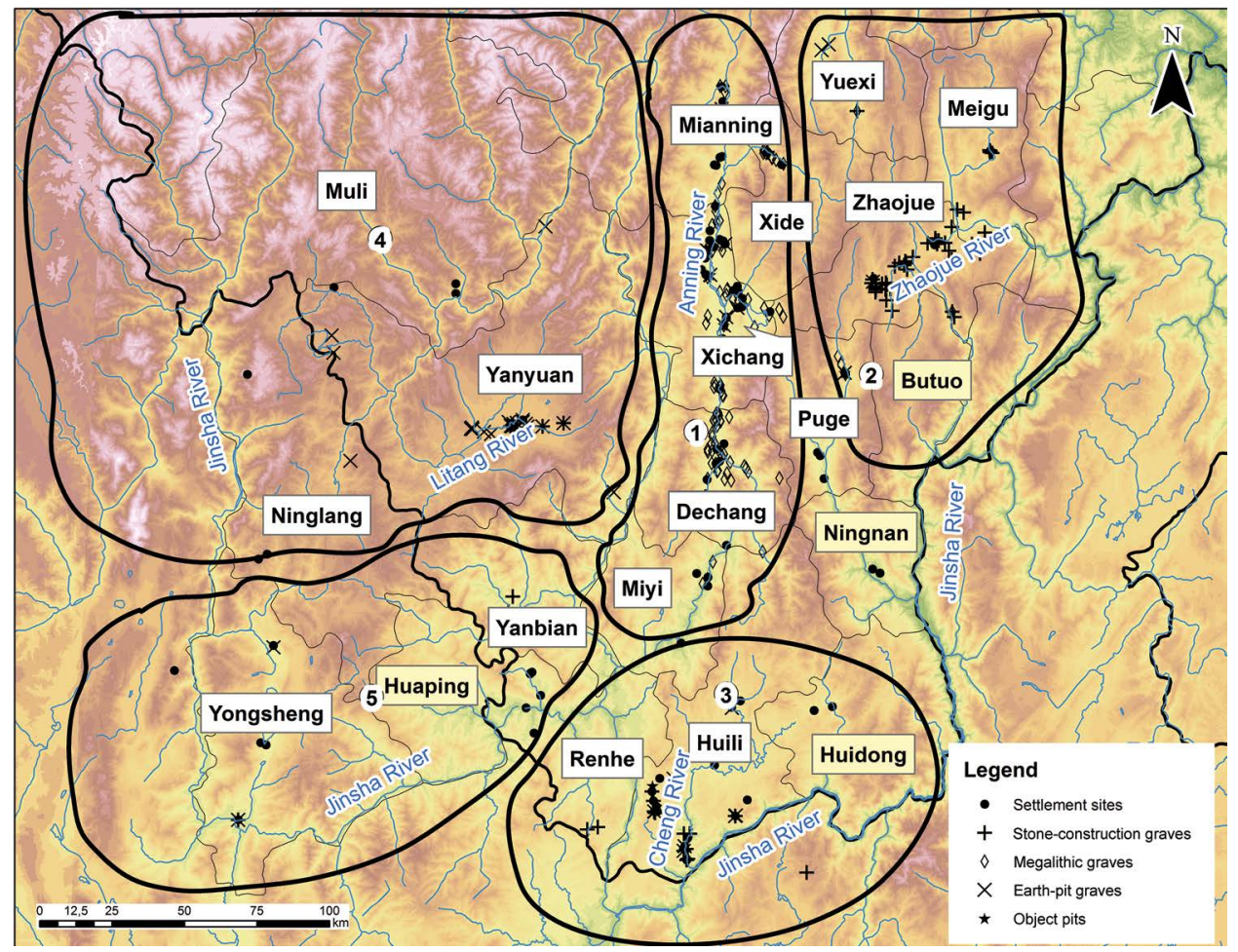

Fig. 2. Subregions and archaeological sites of the Liangshan region: 1) central area (Anning River Valley); 2) northeastern area; 3) southeastern area; 4) northwestern area; 5) southwestern area. 
Palaeoecological research on the region is still at a very early stage, but recent research suggests that the conditions for agriculture may have been less ideal in the past than they are at present (D'Alpoim Guedes 2013, 2015; D'Alpoim Guedes and Butler 2014). Relative differences between the subregions would probably have been similar in the past to what they are today, so present-day climatic conditions serve as a proxy for current research. The Anning River Valley (encompassing Xichang City and Dechang, Mianning, and Miyi Counties) in the center of the research area is the most attractive for agricultural purposes, with a mild climate, ample rainfall, and fertile soil on largely flat terrain (Fig. 2, area 1). The northeastern area, with Zhaojue 昭覺縣 and Yuexi 越西縣 at its center, has a temperate climate with cold winters. Its sparse flat lands are not particularly fertile, but some of the river valleys allow for settled lifestyles with crop production and animal rearing (Fig. 2, area 2). Additionally, the northeast is an important thoroughfare leading from the Chengdu Plain to Yunnan and Southeast Asia.

The southeastern area includes Huili, Huidong, and Ningnan Counties. It has a few wide and fertile river valleys with warmer weather than that of the northeast, but is surrounded by high mountains that isolate it from other parts of Sichuan (Fig. 2, area 3). An extensive river network connects the southeast with areas farther west and north, however, and the terrain gently slopes down toward northern Yunnan. The area is made even more attractive by ample resources, most importantly copper and tin, that were much coveted by metal-producing groups throughout western China.

In the west, the contrasts between valleys and mountains are quite pronounced. Flat areas such as the Yanyuan 鹽原 Basin in western Sichuan and lake depressions of Luguhu 魯固湖 and Chenghai 程海 in Yunnan are rare among the towering peaks of the Hengduan Mountain Range 橫斷山脈. Furthermore, all of these flat areas are located at high elevations prone to frost, making them unsuitable for agriculture. While the valleys in northwest Yunnan are relatively warm, Yanyuan Basin is very dry and has cold winter nights. Nevertheless, high sun intensity and an extensive river network, as well as important salt resources make Yanyuan an attractive place. Muli County 木里縣 in the northwest is dominated by even higher mountains that are only sparsely inhabited and have seldom been explored archaeologically (Fig. 2, area 4).

Southwest Liangshan, including the counties of Yongsheng and Yanbian 鹽邊, encompasses a wide range of elevations from the high mountain ridges of up to $3600 \mathrm{~m}$ running down from the northwest to river basins and wide valleys below $1000 \mathrm{~m}$ (Fig. 2, area 5). The southwest is notably warmer and more humid than areas north, but the high sunshine intensity is similar to that of Yanyuan. Additionally, the local soils are rather fertile, making the southwest an attractive place within which to settle.

\section{ARCHAEOLOGICAL MATERIAL AND ANALYTICAL APPROACH}

The local archaeological material is as varied as the environment. It includes different types of grave forms, settlement sites, and object deposits. The material basis for the present study is comprised of 107 settlement sites, 1059 burials from 213 grave sites, and 15 object deposits and single finds compiled from excavation reports, material collections in local research institutes, and personal excavation participation and survey work (Appendix A). 
The majority of settlement sites were observed in the Anning River Valley, while the northeastern and southwestern areas were represented nearly exclusively by burial material. So far, only two settlement sites are known to have been found in northwestern Liangshan. Throughout the whole region, settlement sites are usually very small, often single-phased, and characterized by thin cultural layers (Hein 2015). All sites hold a number of refuse pits and a few small buildings, most of them semisubterranean houses or waddle-and-daub structures, with the sole exception of one stone house discovered in Muli in the northwest. A few kilns have been reported from sites in the central and southeastern areas of Liangshan.

The grave sites encompass single graves, small grave groups, and a few large cemeteries of sometimes over a hundred graves. Earth-pit graves (most of them with single interments) have been reported from the central, southeastern, and southwestern areas. Various forms of stone-construction graves are known from the northeast (mostly multiple secondary interments), southeast (mostly single primary interments), and southwest (single as well as multiple interments, mostly primary). The Anning River Valley is furthermore known for its megalithic graves containing multiple primary interments of sometimes over a hundred individuals. The grave assemblages vary greatly between subregions and time periods.

The material available for analysis includes ceramics, stone tools, a few bone items, and metal objects (mostly bronze, but some iron, gold, silver, and composite items) in the form of personal ornaments, weapons, or tools and a few vessels, coins, pieces of armor, and horse harnesses, as well as possible ritual objects such as staff heads, stands, bells, and drums. The assemblages combine particularly local features with signs of outside contact (Hein 2014a). These connections allow for cross-dating finds that are otherwise difficult to place in time. Radiocarbon dates are only available for a limited number of sites. Furthermore, in many cases these dates are of limited reliability as they are based on only a single sample per site or layer. The present article therefore relies mostly on traditional stratigraphic and typological methods to establish a chronological scheme for this region.

Typology and classification have been at the core of archaeological work since its beginning as a discipline as both a way of sorting the large number of objects that come out of the ground and a way of making sense of what we see in the archaeological record. Ceramics are chronologically sensitive due to the high frequency of breakage, the plasticity of the medium, and ubiquity in the archaeological record. Slight, incremental changes in ceramic form or decoration can reflect changes in stylistic preferences as they occur over time within one and the same cultural tradition. Larger or more sudden changes may indicate foreign influence or major changes in cooking or eating customs. As a reflection of subsistence systems, stone and bone tools reflect differences between various prehistoric groups as well as major changes in economic activities within one group or region, sometimes necessitated by population growth, human movement, or climate change. Tools are therefore not only very useful for identifying and distinguishing among subsistence communities, they can also be indicators of temporal changes in subsistence systems and intergroup relations.

While ceramics and stone tools are usually discarded when broken, metal objects tend to be melted down and the raw material reused when the objects themselves have become unusable. The only exceptions would be ritual contexts in which people decided to deposit metal objects in the ground and thus took them out of the cycle of melting, recasting, and reusing. Metal objects therefore mainly occur in graves. 
In such contexts, metal ornaments, weapons, and tools can be typologically compared with the aim of establishing the relative chronological position of one grave to another. Burial forms and mortuary traditions likewise can be compared and placed in relative chronological position to each other. Grave forms may even show gradual changes over time that allow for establishing a temporal sequence.

Comparative work with the aim of establishing a chronological sequence of features, layers, and sites requires detailed typological work on all object and feature types, an undertaking that cannot be reported in a single article. The present study therefore draws upon classifications established in a more detailed study of all the archaeological material from the Liangshan region (Hein 2013). The artifacts were first grouped by raw material and the characteristics and functional constraints on the various materials were described to establish function. Various aspects of functionality, including "technofunction" (utilitarianism), "sociofunction" (using an object to express social status), and "ideofunction" (using an object for ideological purposes such as in religious ceremonies), influence an artifact's overall form and design (Sackett $1977: 370)$. As technofunction can most easily be inferred based on object form, this was the starting point for my analysis.

In the previous study, I focused on questions of identity and culture contact as reflected in similarities and differences in production techniques and object form and decoration as well as object usage (Hein 2014a). On the basis of this work, the present study describes object assemblages and features at first separately by site and then sets the sites into spatial and chronological relationship to each other based on stratigraphic evidence, typological comparison of objects and grave types, and radiocarbon dates where available. The study thus starts on the micro-level of local analysis and then gradually widens the gaze to bring increasingly larger portions of the research area into the picture through macro-level analysis. In this fashion, this article establishes cultural sequences for the various subregions from the earliest known settlements to the first century A.D., before discussing general trends observable throughout the research area.

\section{CURRENT STATE OF RESEARCH}

Multi-phase sites with thick cultural deposits provide the basis for developing a chronology for southwest Sichuan. These are combined with radiocarbon dates and typological comparisons with material from well-dated sites in nearby regions. Nearly all known stratified sites in the Liangshan region are located in the central Anning River Valley (i.e., Xichang Dayangdui, Yingpanshan, Ma'anshan, and Mianning Sanfentun). ${ }^{2}$ Several cultural phases have also been observed at Xichang Henglanshan, Lizhou, Mimilang, Qimugou, and Yongsheng Duizi in northwest Yunnan. Most of the existing radiocarbon dates are from samples taken from the Anning River Valley. On the basis of these findings, Jiang Zhanghua (2007) proposed a widely accepted three-phase chronology for the Anning River Valley: 1) the Henglanshan phase; 2) a transitional phase (represented by Xichang Lizhou, Dayangdui, and Mimilang); and 3) a third phase dominated by megalithic graves.

Finer chronological divisions amongst these phases remain much debated. Various chronological schemes have been suggested for the megalithic graves, for instance. Some are based on grave form, some on ceramic types, others on both. Jiang (2007) distinguished two types of ceramic objects among megalithic grave assemblages but, 
since stratigraphic evidence was lacking, did not claim that they belonged to two different time periods. Song Zhimin (1991) proposed a scheme of four construction types that he assigned to different chronological periods from the fifth to the first century B.C. Tong Enzheng (1990) developed a similar scheme but with three instead of four grave types and phases. A publication summarizing comparisons of objects from other regions with those found in megalithic graves in the Anning River Valley provided a chronological scheme consisting of three phases (Sichuansheng et al. 2006a). The main difficulty in establishing a chronology here stems from the nature of the megalithic graves themselves. Some had a long use-life and contain objects from a variety of time periods, while others had shorter use-lives. Furthermore, assemblages differ greatly from grave to grave, making it difficult to compare them. Thus, most of the chronologies suggested so far can only be applied to a limited number of graves and none of them have been universally accepted.

As far as absolute dates are concerned, it is generally agreed that the earliest megalithic graves were built during the fifth century B.C., whereas Han coins found in the latest graves securely date them to the early first century A.D. In a recent publication on stone-cist graves in the corridor between Sichuan, Yunnan, and the QinghaiTibet Plateau, Luo Erhu (2012) boldly proposes a five-phase chronological framework encompassing all graves with stone installations in Southwest China, excluding only the megalithic graves. Grave forms and their contents differ so vastly from location to location that suggesting a uniform developmental sequence and chronology for all of them is highly problematic. Indeed, Luo's characterization of his five phases remains vague, and the graves from the Liangshan region do not fit his scheme.

Previous research suggests that the development of stone-cist graves in the upper Min River Valley in central Sichuan followed a common sequence (He 2009; Smith 2001; Xie and Jiang 2002). The situation is more problematic in northern Yunnan because of wide regional variability in grave construction and content. Nonetheless, intensive excavation work in recent years has allowed researchers to make considerable strides toward developing relative and absolute chronologies of prehistoric sites in Yunnan (Fan 2007; Xu 1999; Yao 2010). These can be used for comparison with material from southwest Sichuan. The same applies to recent discoveries from Yunnan. Excavations at multi-phased sites with particularly thick deposits and rich assemblages at Jianchuan Haimenkou (Yunnansheng 1958; Yunnansheng, Dalizhou, and Jianchuanxian 2009) and Dali Yinsuodao (Yunnansheng et al. 2009) provide important stratigraphic evidence. Comparing materials from later-period sites in Liangshan with Han material from Sichuan and other places also supports the development of a chronology for the Liangshan region. The vessel typology and chronology proposed recently by Psarras (2015) is particularly useful in this regard.

\section{DEVELOPING A NEW CHRONOLOGICAL FRAMEWORK}

Traditional methods of object typology, evidence of changing burial customs and settlement patterns, and hard evidence from site stratigraphies together provide the basis for establishing a relative chronological framework for the Liangshan region. Considering the small number of radiocarbon dates available for the research area, comparing objects from the Liangshan region with finds from more reliably dated sites in other regions is the only way to suggest absolute dates for relative chronological periods. A major difficulty inherent in this comparative approach is that the span 
of object usage might differ significantly between regions. For instance, an object type that reached the peak of popularity in the Chengdu Basin during the second century B.C. may only have been adopted in the western mountains several decades later and might then have continued to be used there for several centuries after falling out of fashion in its place of origin. The potential delay or differences in usage or interpretation of specific object forms or decorative motives becomes even more likely for comparanda from places as far away as the northern steppe or the Central Plains. Additionally, Southwest China is characterized by a wide variety of object forms that have no parallels elsewhere, making cross dating difficult.

Another major difficulty in developing a chronological framework for southwest Sichuan is the great diversity of the archaeological material between different subregions and the uneven state of research in the population centers of the central Anning River Valley, the river valleys of the southeast, and the high western and northeastern mountains (Hein 2013:14-17). While present-day Xichang, Dechang, and Mianning in the Anning River Valley have been relatively well explored, hardly any sites are known from Muli in the northwest. All proposed absolute and relative dates provided below are suggestions based on currently available material. The chronology developed here will have to be amended as new evidence becomes available.

In the following sections, I introduce the archaeological finds by subregion starting from the well-researched Anning River Valley, before expanding to include the remote mountains of the northwest area.

\section{CENTRAL LIANGSHAN: THE ANNING RIVER VALLEY AND ADJACENT MONTANE AREAS}

\section{Early Settlement Finds and Earth-Pit Graves}

The Anning River Valley is divided into three subsections, including the southern counties of Dechang and Miyi, Mianning County to the north, and the city of Xichang in the middle. Early assemblages differ somewhat between each subsection but become increasingly similar over time. To show this development and suggest dates for the known sites, I describe the most important assemblages in some detail and connect them to absolute dates where possible.

Central Anning River Valley Sites around Xichang - Developments in the central Anning River Valley around Xichang are fairly well understood and can be grouped into five phases: 1) early Henglanshan (Henglanshan); 2) late Henglanshan (Ma'anshan, Lower Qimugou, and Lower Yingpanshan); 3) an early earth-pit grave phase (middle Lizhou, early Dayangdui, and Yangjiashan); 4) a pre-megalithic phase (late Lizhou, middle Dayangdui, and Mimilang); and 5) the megalithic phase.

Early Henglanshan is represented by the type site Xichang Henglanshan, Layer 3, dating to $2112 \pm 62 \mathrm{cal}$. B.C., and Layer 4 to $2545 \pm 47$ cal. B.C., with hardly any differences between the assemblages. ${ }^{3}$ The material is characterized by coarse sandtempered low-fired red-brown ceramics accompanied by polished stone woodworking tools, arrowheads, and some perforated stone knives (Fig. 3.1-9). The late Henglanshan sites of Xichang Ma'anshan, Lower Qimugou, and Lower Yingpanshan hold ceramics largely identical with each other and very similar to those from late Henglanshan, but with somewhat different decorations and including leaf-shaped vessel bottoms and double-perforated knives, as have been found at Henglanshan 


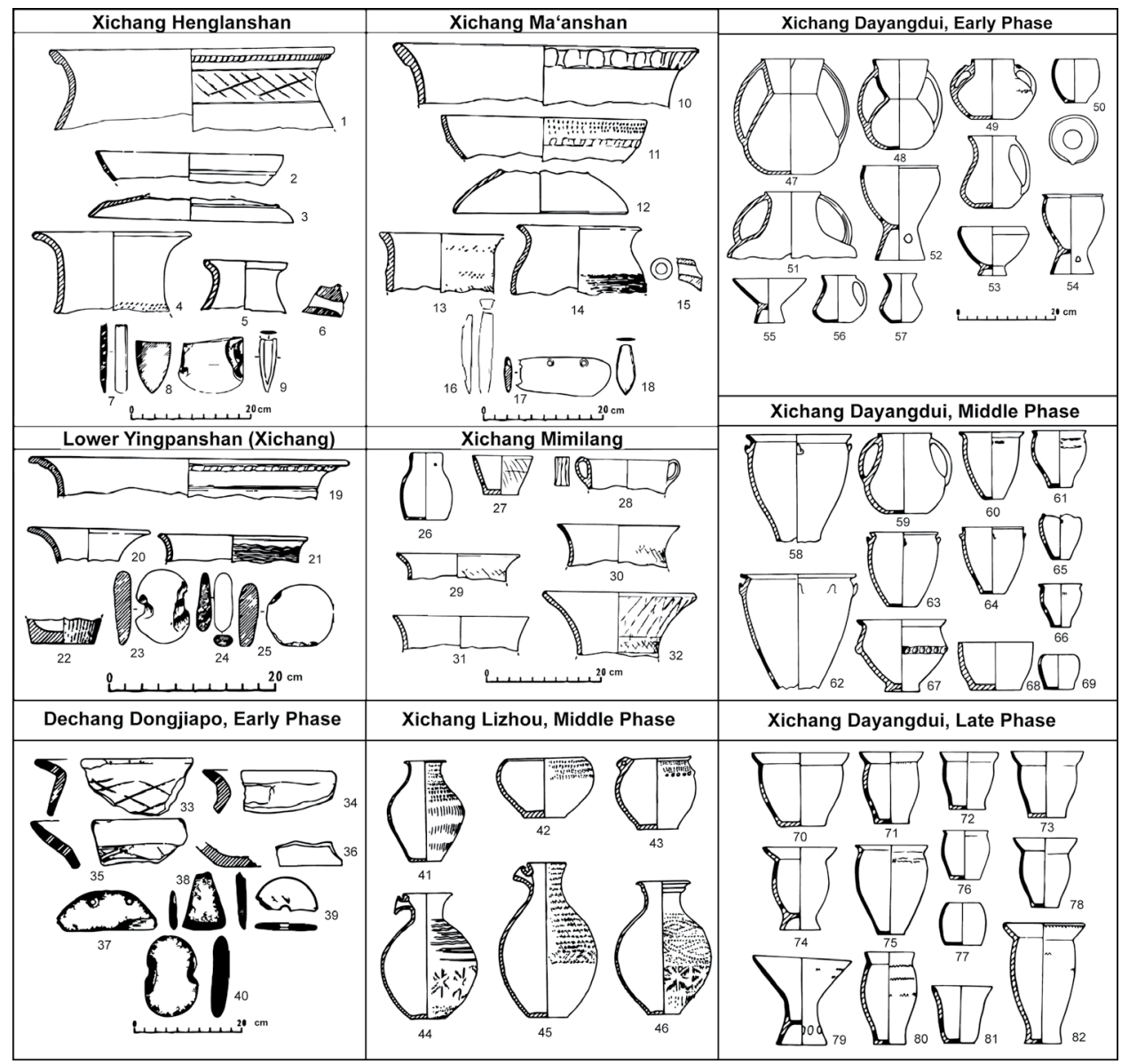

Fig. 3. Ceramics and stone tools: 1-9 from Xichang Henglanshan (Early Henglanshan) (after Chengdu et al. 2006: figs. 8-11); 10-18 from Xichang Ma'anshan (after Chengdu et al. 2006: figs. 17-22); 19-25 from Lower Yingpanshan (after Chengdu et al. 2007b: figs. 4-6); 26-32 from Xichang Mimilang (after Jiang 2007: fig. 4; Liangshan et al. 2006: figs. 10, 11); 33-40 from Dechang Dongjiapo, Early Phase (after Zhou 2011: figs. 6, 7, 13, 14, 19, 20); 41-46 from Xichang Lizhou, Middle Phase (after Jiang 2007: figs. 2, 3); 47-83 from Xichang Dayangdui (after Xichangshi et al. 2004: figs. 7, 18, 25).

(albeit only as surface finds). The poorly documented early Lizhou site is said to have held similar finds and likely belongs to the late Henglanshan phase as well.

The settlement material of early Lizhou is superimposed by earth-pit graves with rich ceramic assemblages that fall into two types. One consists of vases and ewers whose surfaces are covered with geometric patterns (graves AM2, AM6, AM10, BM4; Fig. 3.41-46), and the other is comprised of double-handled jars and large numbers of bowls, but no spouted or decorated vessels (graves AM9, BM3, BM8). Since BM4 is cut by BM3, it is likely that the second assemblage type dates later than the first. The second type also encompasses a stout jar with a horn-shaped handle nearly identical to a vessel from a Han grave observed at Lizhou (Lizhou 1980: fig. 6.5), which supports a later date. 
The ceramics from the pre-Han graves of late Lizhou are all sand-tempered, lowfired, red-brown in color, and of low quality. Thick ring-handles are attached to the upper part of squat jars that are sometimes decorated with net patterns (Fig. 3.41-46). By contrast, the ceramics from the earth-pit graves of early Dayangdui are of highfired black-brown fine ware and have a black slip without decoration (Fig. 3.47-83). The handles are long and thin and reach from the high collar to the low belly of these round-bottomed, ovoid vessels. Both in ceramic quality and execution, the early Dayangdui ceramics strongly resemble finds from Qijia Culture sites in Gansu and Qinghai (Debaine-Francfort 1995: figs. 19, 28, 98, 116; Zhongguo 1975: figs. 16, 18). If the earth-pit graves at Dayangdui were indeed built by a group with Qijia connections, this would suggest a date between c. 2200 and 1750 B.C., which would postdate Lower Yingpanshan and early Xichang Lizhou, and either contemporaneous with or slightly later than middle Xichang Lizhou.

Double-handled vessels were also found at Mimilang, but their handles are small, ring-shaped, and attached to straight necks of wide-bodied vessels very different from Lizhou or Dayangdui finds, but more similar to objects from megalithic graves (Fig. 3.26-32). At Mimilang, two radiocarbon dates were taken, one from Layer 5 $(89 \pm 41 \mathrm{cal}$. A.D.) and one from Layer 4 (1008 $\pm 60 \mathrm{cal}$. B.C.), but as the date from Layer 4 is earlier than the one from Layer 5 instead of the other way around, and the dates rely on only one charcoal sample each (Jiang 2007:10), this late date is likely faulty. Stylistic evidence indicates a date contemporaneous with middle Lizhou and early Dayangdui.

The site of Dayangdui has three phases, an early one characterized by the graves with high-fired ceramics described above, a middle one characterized by object pits, and a late one consisting of megalithic graves. The ceramic pits of middle Dayangdui hold double-handled jars similar in form to those from early Dayangdui, but they consist of red or brown sand-tempered ceramic material rather than high-fired black fine ware (Fig. 3.47-83). They are rather different from objects from Gansu, but resemble ceramics from stone-cist graves at Wenchuan Zhaodiancun in northwest Sichuan (Shi 1999: fig. 3). Wenchuan Zhaodiancun dates to around the eighth to seventh centuries B.C., as might middle Dayangdui.

Overlaying early Henglanshan-phase settlement remains, the ceramic deposits of Upper Yingpanshan include very large urns (with or without application bands) and double-handled vessels similar to those at early Dayangdui. These vessels are accompanied by net-weights as seen in the lower layers of Yingpanshan and other vessels with net patterns similar to ceramics at Xichang Mimilang, Dechang Dongjiapo, and Wangjiaping. The high stems of Upper Yingpanshan are reminiscent of objects from Dayangdui and Qimugou in Xichang, which are in turn related to material from megalithic graves. Upper Yingpanshan therefore likely postdates middle and maybe even late Dayangdui.

Southern Anning River Valley Sites around Dechang and Miyi - In the south, we can see three early phases. The first phase is represented by Maojiakan in Dechang County, a site characterized by microliths and coarse ware. The second phase is represented by early Dongjiapo and Wangjiaping sites. The ceramics at these sites are similar to those from Henglanshan both in quality and form, but not in decoration (net and cross patterns instead of simple line incisions). The third phase is represented by late Dongjiapo, which shows close similarities to Mimilang in Xichang. 
The microliths at Maojiakan suggest a way of life different from that common around Xichang. Similarly, Wangjiaping holds coarse woodworking and processing tools very different from the fine perforated knives found around Xichang. These finds indicate a general difference in subsistence between the two areas. Nevertheless, the ceramics from Wangjiaping are similar to those from Henglanshan both in quality and form, though not decoration, since they feature net- and cross-patterns instead of simple line incisions. Radiocarbon dates confirm that Wangjiaping Layer 3 (2360 \pm 69 cal. B.c.) is contemporary with early Henglanshan, but Maojiakan may be of an earlier date.

The ceramics and stone tools from early Dongjiapo are similar to objects from Wangjiaping (Fig. 3.33-40); however, they are accompanied by a large number of net-weights nearly identical to those from Yingpanshan, indicating parallels in subsistence practices though not ceramic traditions. Incised net patterns, zigzag decorations, single-handled vessels, and fine-polished stone tools resembling objects from Mimilang and from megalithic graves are particularly numerous in late Dongjiapo. Both Mimilang and Dongjiapo contain wide outward-flaring vessels with net patterns. Early Dongjiapo thus likely postdates Wangjiaping, whereas late Dongjiapo might be contemporaneous with Mimilang.

Northern Anning River Valley Sites around Xide and Mianning - Hardly any sites predating megalithic graves are known to exist in the northern part of Anning River Valley. The only properly excavated sites are Gaopo Zhaojiawan, both in Mianning County. Assemblages from these two sites are nearly identical with each other, but very different from anything found in other parts of Anning River Valley. These finds in Mianning consist of red-brown and gray sand-tempered wheel-thrown pottery, mainly in the form of carinated wan bowls and large urns and jars. Most of the jars have a row of lug handles around the shoulder and leaf-vein-impressed ring-footed bottoms; a few have high stems and conical spindle whorls. Zhaojiawan additionally holds some pottery with narrow band-handles and Gaopo yields many coil-built, duck-beakshaped objects usually interpreted as spouts. Single lug handles have been found at middle Dayangdui in Xichang and Dongjiapo in Dechang, but no other close comparanda have been found in the Anning River Valley. Instead, the finds from Mianning more closely resemble objects from the Yeshishan site in Ludian County in northeastern Yunnan (Yunnansheng, Zhaotongshi, and Ludianxian 2009), which in turn shares some traits with Jigongshan in Weining County in Guizhou Province (Guizhousheng et al. 2006; Liu and Sun 2009).

The excavators date Yeshishan to 1300-1900 cal. B.C., but the earlier date is based on two problematic dates with wide error ranges: $1217 \pm 121 \mathrm{cal}$. B.C. and $1347 \pm 130$ cal. B.C. Based on five radiocarbon dates with less wide error margins, Jigongshan is dated more securely to c. 1400-1100 cal. B.c. The radiocarbon dates from Gaopo are $1379 \pm 39$ cal. B.C. for Layer 3, $1316 \pm 47$ cal. B.C. for Layer 2, and $1179 \pm 47$ cal. B.C. for Layer 1. The radiocarbon dates from Zhaojiawan are $1316 \pm 47$ cal. B.C. for Layer 2 and $972 \pm 53$ cal. B.C. for Layer 3. If these dates are correct, then the ceramic form tradition shared by all four sites likely originated in Jigongshan and reached Mianning through Yeshishan. The relationship between Gaopo/Zhaojiawan and other sites in the Anning River Valley remains problematic, however. Chronologically, the lug handles of Dayangdui and Dongjiapo suggest that Gaopo predates middle Dayang- 
dui; the band handles at Zhaojiawan and late Dongjiapo indicate Zhaojiawan might be slightly later than Gaopo.

Finds from Anning River Valley suggest that various local groups were interconnected and came into increasingly closer contact with each other as well as with people from other areas over time. This trend becomes even more apparent in the following phase characterized by megalithic graves. During the time megalithic graves began appearing in the Anning River Valley, settlements and earth-pit graves in the neighboring mountains of Puge and Xide show very different assemblages surprisingly consisting of high-fired fine ware in the form of undecorated, crudely formed cups and stout jars without handles. Examples are observed at Tianba and Zhongcun and in the early settlement layers of Xiaoxingchang (all three sites in Puge). Albeit executed in different ceramic materials, the plain jars found at Xiaoxingchang resemble finds from Yangjiashan in Xichang. Since they are overlain by megalithic graves, they can be dated to the pre-megalithic phase. Assigning an absolute date is more difficult and will require further fieldwork and scientific dating.

The stone tool assemblages at these as well as at later sites are characterized by a considerable number of arrowheads and coarse grinding tools. These artifacts indicate a mixed form of subsistence dominated by hunting, which is very different from the agricultural assemblages of the Anning River Valley. Identical tool assemblages and high-fired plain jars have been reported from Wadaluo in Puge, but some of the cups and stout jars resemble objects from the megalithic graves of Wanqiu in Miyi (albeit of a finer ceramic quality). Handled or spouted jars or incised and impressed decoration motifs known from megalithic grave assemblages in the Anning River Valley are not common at Wadaluo. The absolute date of Wadaluo is not entirely clear, but the site likely postdates Tianba and Zhongcun and may predate the megalithic graves of Xiaoxingchang.

\section{Megalithic Graves and Related Sites in the Anning River Valley}

The existence of megalithic graves suggests that a complex set of burial rituals was common throughout the entire Anning River Valley and the immediately adjacent mountains of Puge and Xide. However, grave form, mode of interment, and object assemblages differ amongst the sites in these areas and change over time. Based on comparisons of ceramic form and quality, the presence or absence and type of other burial goods, grave size, interment type, and associated rituals, I distinguish four main phases (I-IV), with Phase II and III each further divided into two subphases (Table 1).

One major difficulty with comparing and dating megalithic graves in southwest Sichuan is that many have been used for several instances of interment over extended periods of time. To mitigate this problem, I initially relied on: 1) graves used for a single instance of interment; 2) stratified sites containing megalithic graves (i.e., Xiaoxingchang in Puge and Dayangdui, Lizhou, Maliucun, Mimilang, and Qimugou in Xichang); 3) comparing material from well-dated sites; and 4) radiocarbon dates. I then integrated data from graves with longer use-lives.

The earliest megalithic graves were found at Dayangdui and Tianwangshan (both in Xichang). These graves were used for single instances of probably secondary interment of a small number of people. The majority of ceramic vessels associated with 


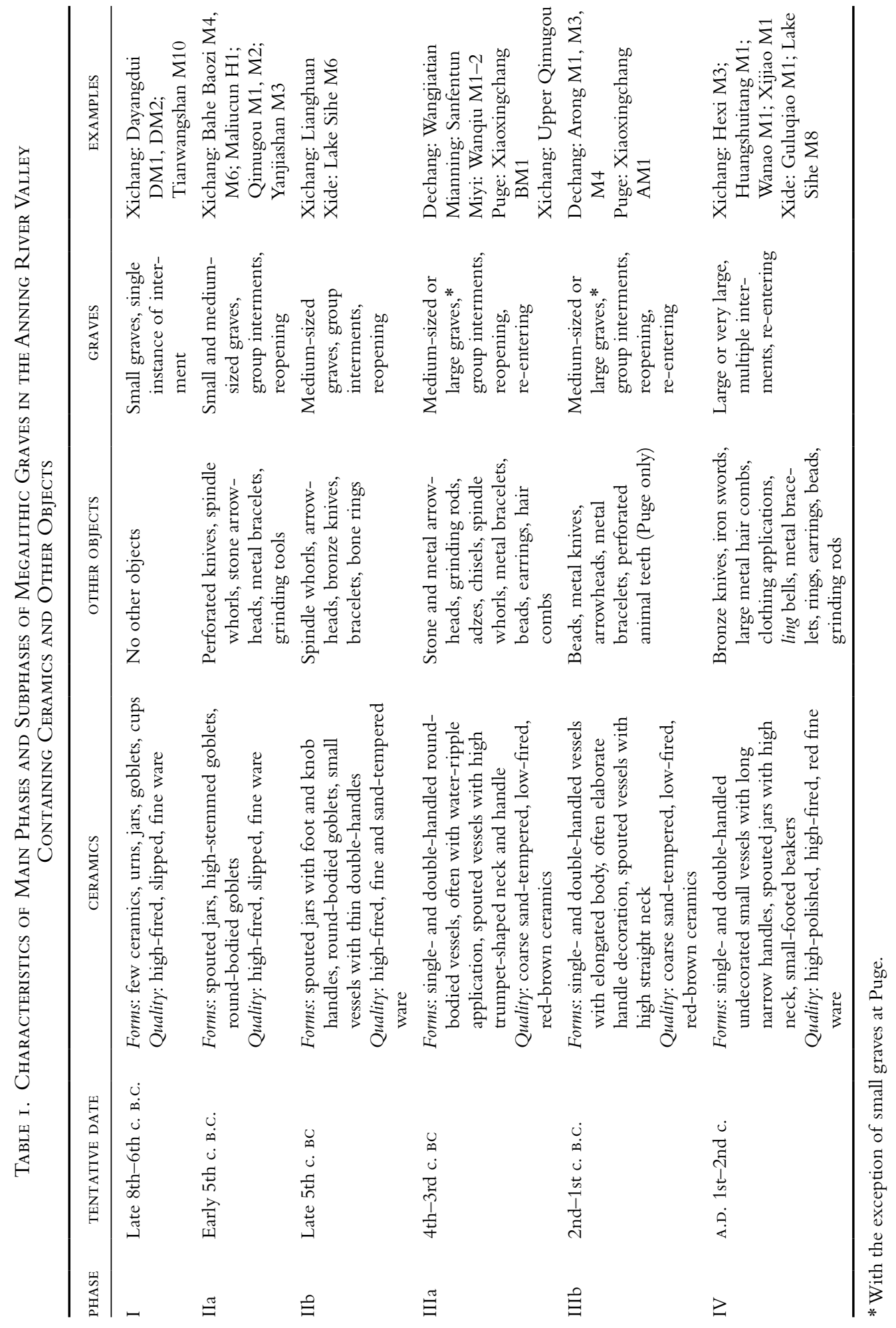


these graves were found in nearby pits. Neither graves nor pits contained weapons, tools, or personal ornaments. The associated ceramic assemblages consist of drinking and pouring vessels, suggesting that communal rituals were held at the burials. The ceramic quality resembles that of middle Dayangdui finds, but the forms differ, with footed beakers and plain jars with high outward-flaring collars instead of large storage jars. Based on these differences and the stratigraphy of the sites, Phase I of the megalithic graves may be dated to the late eighth to sixth centuries B.C.

These early megalithic graves are found exclusively in the central Anning River Valley around Xichang, but from Phase II onward, the custom of building megalithic graves extends farther south and into the eastern mountains of Puge and Xide. The only radiocarbon dates obtained from megalithic graves were taken from human bones in Xiaoxingchang AM1 and BM2 in Puge; both date to $601 \pm 127$ cal. B.C. Graves AM1 and AM2 at Xiaoxingchang are relatively small with a limited number of interments similar to those at Dayangdui and Tianwangshan, while graves BM1-3 are medium-sized and hold up to 125 skeletons each. The assemblages combine a few high-fired, undecorated ceramic vessels typical of Puge with a considerable number of knives, arrowheads, and personal ornaments. Many Phase II graves in Xichang, such as Bahe Baozi M4 and M6 or those at Lianghuan, combine a few ceramic vessels (mainly spouted jars) with a few knives and spindle whorls, again similar to finds from Puge and Xide.

Besides megalithic structures, the earth-pit graves of Qimugou M1 and M2 and the ceramic pits of Maliucun and Upper Yingpanshan (all in Xichang) furnish a large number of ceramic vessels, including goblets, ewers, and jars made of the same high-fired, black-brown fine material as the ceramics from the megalithic graves of Dayangdui. These finds indicate a shared ceramic tradition. The Qimugou earth-pit graves superimpose the settlement remains of Lower Qimugou discussed above and are in turn superimposed by settlement Layer 3, whose coarse sand-tempered handled vessels resemble finds from the megalithic graves of Wanqiu in Miyi and Arong in Dechang (Fig. 4.1-12). At Qimugou, one earth-pit grave with three chopper stones (M3) and one round pit with one large urn and one smaller jar (W1) cut into Layer 3. The urn resembles objects from the Yingpanshan deposits, which are superimposed by Han material, and the jar resembles Han-style ceramics indicating a Western Han date (206 B.C.-A.D. 9). The chronological sequence in Xichang is therefore Mimilang

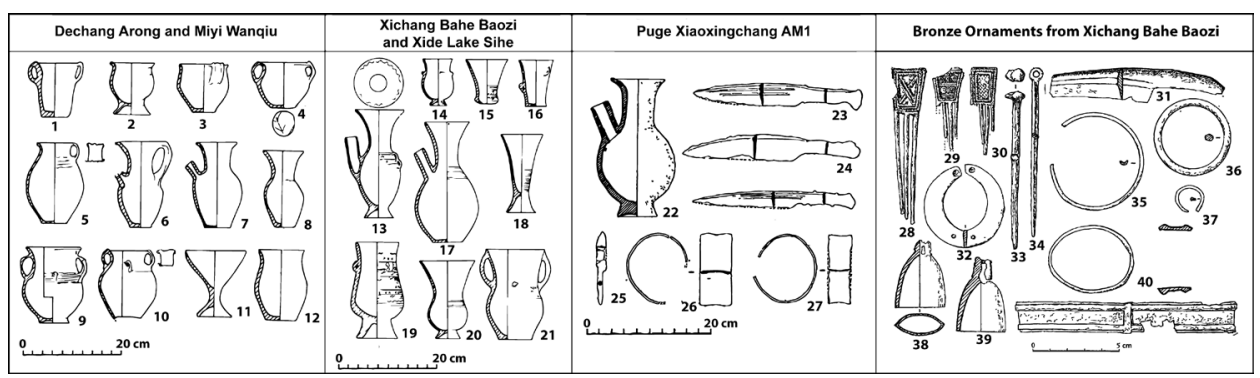

Fig. 4. Finds from megalithic graves: ceramics: 1-4, 6, 8, 9, 11, 12 from Miyi Wanqiu; 5, 7, 10 from Dechang Arong; 13, 14, 16-19 from Xichang Bahe Baozi; 15, 20 from Xide Lake Gongshe (after Jiang 2007: figs. 6, 7); 22-28 from Xiaoxingchang AM1 (Liangshan and Pugexian 1987: figs. 8, 9); bronze ornaments: 29-40 from Xichang Bahe Baozi (after Sichuansheng and Anninghe 1976: fig. 2). 
(pre-megalithic), Upper Yingpanshan (early Phase IIa), Qimugou M1 and M2 (late Phase IIa), Qimugou W1 (Phase IV).

During Phase IIb (around the fifth century B.C.), we thus see a shift from the fine ware of Phase I and Phase IIa to the red low-fired coarse ware of Phases III and IV. In Phase III, such ceramics come to dominate in the form of globular jars with short band handles that appear for the first time at Qimugou Layer 3 and then in increasing numbers at settlement sites (i.e., Xichang Wangjiatian and Mianning Sanfentun) and in megalithic graves (i.e., Miyi Wanqiu and Dechang Arong) throughout the entire Anning River Valley. Such jars are characteristic of stone-cist graves in the upper Min River Valley dating to the third century B.C. (He 2009). Similar vessels occur in megalithic graves holding iron objects (e.g., Miyi Wanqiu), but they are never found next to ceramics resembling those from Xichang Qimugou M1 and M2. Phase III thus dates approximately to the fourth to third centuries B.C. This third phase also sees the appearance of hair combs (Fig. 4.22-40), small bronze bells, and in the case of Puge perforated animal teeth reflecting changes in personal attire. At the same time, the grave size increases and the number of interments increases. These trends have already started in the latter part of Phase II and continue into Phase IV, culminating in very large graves such as Xichang Wanao. Only in Puge do the megalithic graves stay small, possibly because of lack of space in the narrow mountain valleys. The Phase IV graves are often dated by the presence of Han-style iron knives with ring handles or the presence of daquan wushi 大泉五十 (c. A.D. 9-14) or wuzhu 五銖 (c. A.D. 25) coins suggesting a date of A.D. first or second century at least as terminus post quem.

As many megalithic graves have been reopened several times, any dates suggested by means of object typology can only help to determine one point during the use life of the grave. Xide Lake Sihe M1, for instance, contains both a goblet similar to objects from Xichang Qimugou M1 and M2 and Han objects (coins and a Han-style $f u$ vessel), showing that the grave was likely in use from the fourth to the second century B.C. at least. A large number of objects and skeletons like those observed at Puge Xiaoxingchang BM1 and BM4 or Xide Guluqiao M1 may indicate a long use-life. If the objects all closely resemble each other, however, the large assemblage was more likely the outcome of intensive usage over a shorter period of time (e.g., Dechang Arong). By contrast, at Miyi Wanqiu, the same basic vessel forms occur in a variety of types, suggesting an extended period of use.

Based on these comparisons, it is possible to distinguish four main phases for megalithic graves. Phase I dates to the eighth to the sixth century B.C.; Phase II to the early fifth century B.C.; Phase III to the fourth to the third century B.C.; and Phase IV to the second century B.C. to the early first century A.D. Given the long use-life of some of these graves, Phases II and III might overlap, as might Phases III and IV. The general development, however, is clear: the first graves were small and held single interments with few objects; over time, they grew in size, number of interred, and complexity of associated rituals. The urn pits of upper Xichang Yingpanshan and Xichang Qinmugou are likely connected with megalithic graves, dating to Phases IIa and IV respectively. The earth-pit graves at Xichang Qimugou are contemporaneous with the megalithic graves of Phase IIb, as is the ceramic deposit of Xichang Maliucun.

By incorporating this information into data from the earlier earth-pit graves of Lizhou and early Dayangdui (both in Xichang) and ceramic deposits from middle 


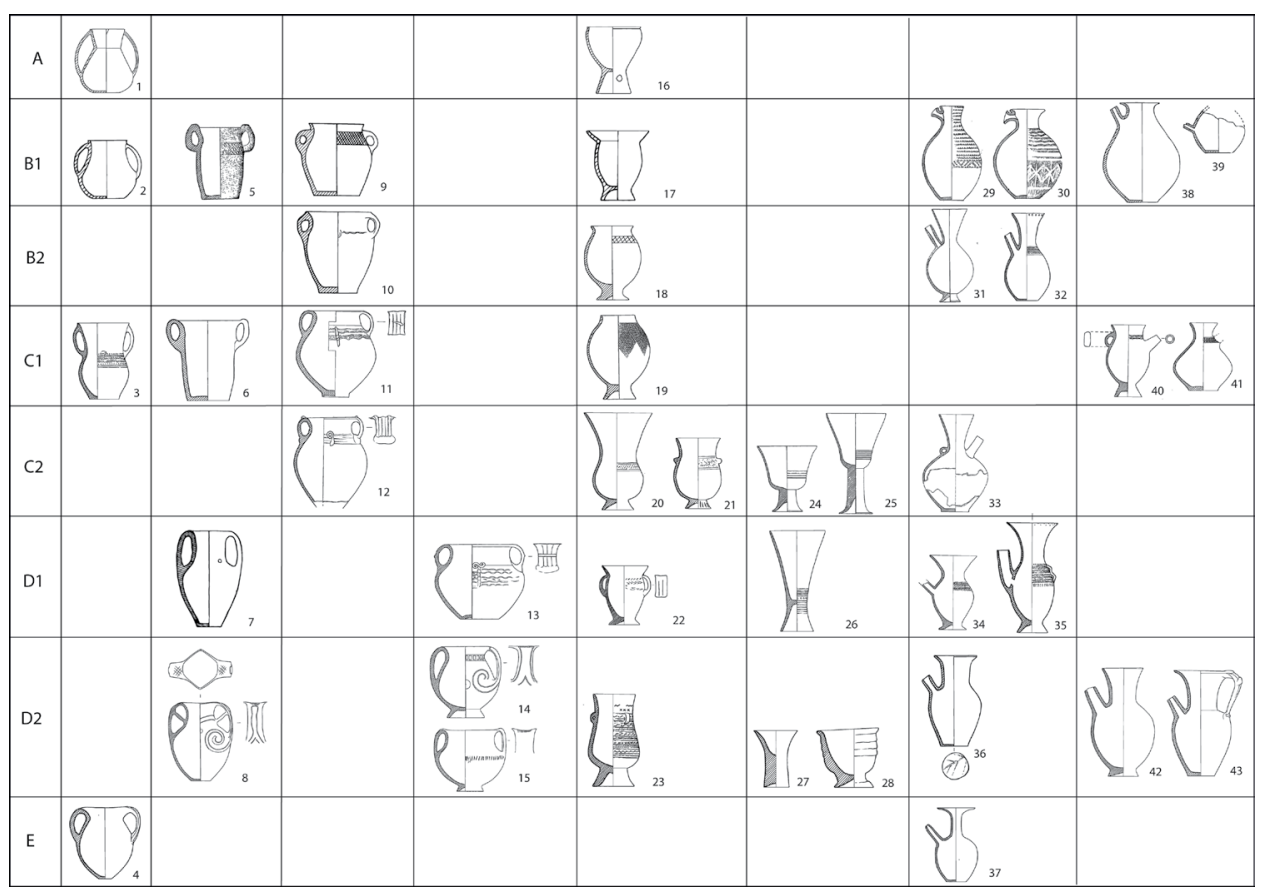

Fig. 5. Typological development of double-handled jars (columns 1-4), goblets (column 5), small-footed cups (column 6), and spouted jars (columns 7-8) found throughout the Liangshan region. Objects: 12, 42 from Dechang Arong; 9, 18, 38, 39 from Huili Fenjiwan; 10 from Huili Guojiabao; 19 from Huili Leijishan; 6, 11, 43 from Miyi Wanqiu; 7 from Ninglang Daxingzhen; 36 from Puge Xiaoxingchang; 20, 21, 28, 32 from Xichang Bahe Baozi; 1, 2, 16, 17 from Xichang Dayangdui; 27 from Xichang Hexi; 22, 34 from Xichang Lianghuan; 5, 29, 30 from Xichang Lizhou; 33, 40, 41 from Xichang Maliucun; 24-26, 31 from Xichang Qimugou; 4, 37 from Xichang Xijiao; 3, 23, 35 from Xide Lake Sihe; 8, 13-15 from Yanyuan Laolongtou.

Lizhou, we can distinguish five main phases and several subphases in ceramic forms in central Liangshan, with the early Dayangdui assemblages falling in a pre-megalithic Phase I and the Lizhou graves and middle Dayangdui ceramics into Phase IIa; megalithic graves then appear in ceramics Phase IIb (Fig. 5).

\section{NORTHEASTERN LIANGSHAN: ZHAOJUE, YUEXI, AND NEIGHBORING AREAS}

While Xide and to a lesser extent Puge are closely linked with developments in the Anning River Valley, people who inhabited other montane areas in northeastern Liangshan do not seem to have adopted the custom of erecting megalithic graves. Instead, various types of smaller stone graves are typical for the area around Zhaojue and Yuexi.

Many different grave forms exist next to each other in Zhaojue County. Since all of them contain multiple secondary burials and only a limited number of often unique objects, or sometimes none at all, assessing their dates is difficult. The only graves that have at least a clear terminus post quem are those containing Han-style objects. The brick-wall-like stone-construction graves at Zhaojue Chike Boxixian clearly imitate Han graves. They contain unique ornaments of semiprecious stone and 


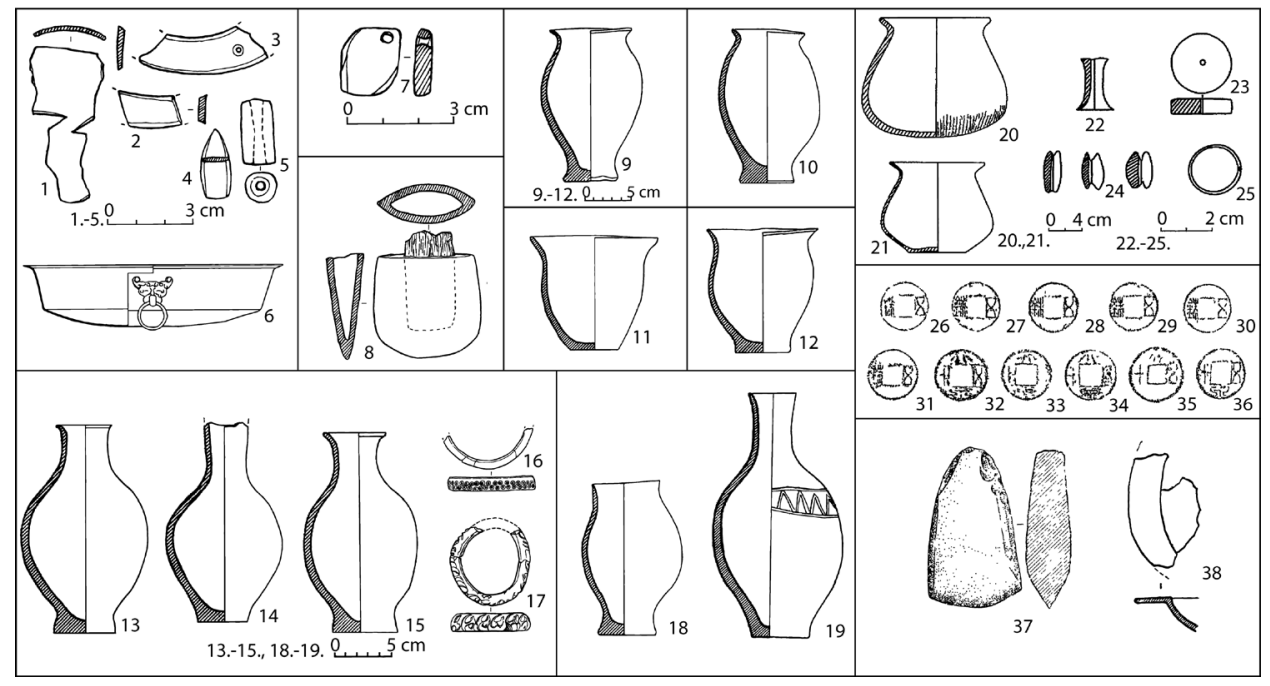

Fig. 6. Objects from stone-construction graves: 1-19 from Zhaojue Eba Buji (1-6 in M1, 7 in M2, 8 and 9 in M3) and Pusu Bohuang (10 in M2, 11 in M11, 12 in M8, 13-15 in M9, 16 and 17 in M3, 18 and 19 in M4) (after Liangshan et al. 2009); 20-36 from Zhaojue Chike Boxixian (after Lianghan et al. 2010: figs. 8, 9); 37-38 from Erba Keku M4 (after Liangshan Yizu Diqu Kaogudui 1981: figs. 7, 8).

metal next to typical Han ceramics and coins, suggesting a date around the first to second century A.D. (Fig. 6).

Zhaojue Eba Buji M1 held a bronze basin nearly identical to objects from Han graves at the Weining and Mancheng sites in Guizhou Province southeast of Sichuan (Guizhousheng and Weiningxian 1981: fig. 11; Zhongguo 1980:58). The form of the finely worked bronze axe found in Zhaojue Eba Buji M3 is common to both Western and Eastern Han sites, indicating a similar date. The single nephrite pendant found in M2 cannot be assigned a date, but as the grave structure of all three graves is the same, they are likely contemporaneous. The metal-basin fragment found in Zhaojue Erba Keku M4 is poor quality and does not resemble any known Han objects. It was accompanied by finely polished arrowheads similar to those from grave M5 and a stone axe similar to an object from M9 (both at the same site). All of these stone items closely resemble finds from the settlement layers of Puge Xiaoxingchang, indicating similar dates.

The ceramics from the stone graves of Zhaojue Fuchengqu show a strong resemblance to finds from Puge and Xichang. The flat-bottomed jars are nearly identical to objects from the settlement layers of Wadaluo and Xiaoxingchang (both in Puge), while the footed bowls are of the same form as those in the early earth-pit graves at Xichang Dayangdui. The graves at Fuchengqu are likely roughly contemporaneous with those at Wadaluo and thus considerably earlier than those at Erba Keku.

Although the graves of Pusu Bohuang and Eba Buji are located on the same hill, the Pusu Bohuang graves are considerably earlier in date. The plain ceramic vessels found in the graves at Pusu Bohuang are again different from ceramics found in other sites in Zhaojue. They resemble ceramics from the stone-construction graves at Xiaotuanshan and Xiaoyingpan in Huili and Yingpanbao in Luquan, which date to the Late Neolithic (see below). 
Even less research has been conducted around Yuexi than in Zhaojue, but the contents of the few earth-pit graves known from Huayang and Liaojiashan in Yuexi are nearly identical with some of the stone-cist graves along the upper Min River (e.g., Sichuansheng and Maowenxian 1983: figs. 12, 13). They contain a large number of bronze vessels, bronze and composite swords, knives, double-handled ceramic jars, and bronze ornaments that date them to the Western Han (206 B.C.-A.D. 9).

\section{SOUTHEASTERN LIANGSHAN: PANZHIHUA, HUILI, AND NEIGHBORING AREAS}

The area around Huili County and Panzhihua City in southern Liangshan developed independently from the Anning River Valley area, but was closely connected to northern Yunnan. After an early phase with cave and open-air sites dominated by microlithic assemblages similar to finds from Yunnan, we see the emergence of settlement communities relying increasingly on agriculture. They buried their dead in earth-pit graves constructed with or without stone and accompanied mostly by ceramic vessels whose forms changed over time. The graves and their assemblages at sites such as Huili Guojiabao, Luluochong, and Zhuanchangba and Xide Guoyuan differ by location farther south or north and show strong connections to communities outside the area southwest of the Liangshan region.

There are numerous cave sites in northern Yunnan (Zhongguo 2009), but Panzhihua is the only place in Sichuan with known cave sites: Yanwan in Xiqu and Huilongwa and Xicaoping in Renhe. Like the open-air Yangjia Wuji site in Huili, the two cave sites in Renhe hold microlithic assemblages and considerable amounts of faunal remains, but are devoid of ceramics. The Xiqu Yanwan cave site is partially open-air. It contains flaked-stone tools and ceramics, but no microliths. It is therefore conventionally dated to the Early Neolithic, while the other cave sites are assigned to the late Palaeolithic. These are only assessments of modes of subsistence, however, not actual dates.

Nevertheless, the differences between ceramics at sites characterized by coarsestone tools compared with sites containing polished-stone tools indicate differences in date. Huili Houzidong and neighboring sites hold peculiar coarsely flaked shouldered axes and adzes (Sichuansheng et al. 2009: figs. 3-5). The associated ceramics (i.e., black-slipped, low-fired, sand-tempered, small to medium-sized wide-mouthed jars) resemble finds from Dechang Maojiakan, indicating a similar approximate date around 2500 B.C.

Ceramics at Huili Dongzui fall into two phases. The first phase is characterized by jars with moderately outward-flaring rims, some of them with finger-tip-impressed appliqué bands, others with incised decoration reminiscent of ceramics at Dechang Wangjiaping (Chengdu, Liangshanzhou, and Huilixian 2008: figs. 5, 10-15). The later layers contain ceramic rims with corded-ware designs similar to finds from Caiyuanzi and Mopandi in Yongren, Yunnan (Yunnansheng 1985; Yunnansheng et al. 2003) and handles with a middle ridge reminiscent of objects from Haimenkou in Jianchuan, Yunnan (Yunnansheng 1995; Yunnansheng, Dalizhou, and Jianchuanxian 2009). Based on these comparisons, Huili Dongzui likely dates to 1500-1100 B.C.

The ceramics at Huili Dongzui are very similar in quality to the low-fired, handthrown, yellow coarse ware from Huili Washitian, but their forms are very different. Instead of handled jars with a corded-ware design, the earth-pit graves and settlement layers at Washitian contain open bowls, plain flat-bottomed jars, and stemmed goblets 


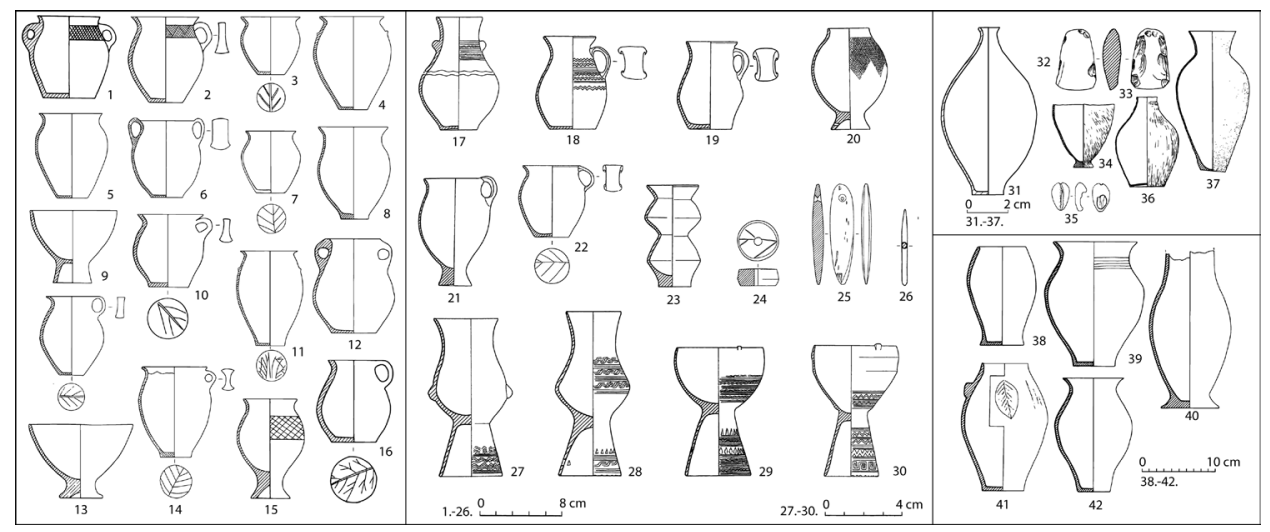

Fig. 7. Objects from Huili: 1-16 from Fenjiwan (after Huilixian et al. 2004: fig. 11); 17-30 from Leijiashan M1 (after Chengdu, Liangshanzhou, amd Huilixian 2009: figs. 3-5); 31-37 from Luquan Yingpanbao; 38-42 from Xiaoyingpan (after Kunmingshi et al. 2007: figs. 8, 18; Sichuansheng et al. 2009: figs. 7-9).

with a net pattern. These ceramics are associated with needles, arrowheads, and axes made of stone, bone, or bronze, and several stone molds for metal tools, all pointing to local metalworking and a later date. The spearhead form of one of the molds is almost identical with finds from Yongsheng Longze dating to the fifth century B.C. (Yang et al. 2009:207-211), and the ge $\mathbf{t}$ dagger-axe mold is typical of the Shu style dating between the sixth and fifth centuries B.C. (Tao 1981). These finds suggest an overall date of the fifth century B.c. for Huili Washitian.

The large cemetery at Huili Fenjiwan has over 150 graves furnished mainly with ceramic objects, all of a quality similar to those from Huili Dongzui and Huili Washitian, while their forms and decorations show parallels with the finds from Anning River Valley sites. Large urns and jars resemble those found in Xichang Qimugou and Xichang Yingpangshan; goblet forms are like those in Dechang Dayangdui and Xichang Tianwangshan, and double-handled vessels and spouted ewers and netpattern decorations are like those from Xichang Lizhou (Fig. 7.1-16). A few graves at Huili Fenjiwan held $y u$ 鋮 axes nearly identical to the axe from Huili Washitian and axes from sites in Yunnan (Li 1983: fig. 5; Xi 1991: figs. 3, 6). A decorated spearhead likewise has comparanda in northern Yunnan (Yunnansheng 1983). These parallels allow a date of around the fifth to the fourth century B.C. to be assigned to Huili Fenjiwan.

The differences amongst the assemblages suggest internal variation within Fenjiwan (e.g., Nos. 9, 18, 38, 39 in Fig. 5). Based on number and type of ceramic vessels and other objects, I distinguish three main groups, with Groups 1 and 3 further divided into three subgroups each (Table 2). The question remains if these groups are chronologically or socially defined. Handled and spouted forms and stemmed bowls are uncommon in early settlement finds in southeastern Liangshan, but all three forms occur together at Fenjiwan. Their association with metal weapons suggests a relatively late date for Group 3 assemblages. Large urn forms from Groups 1 and 2 are hardly ever associated with such objects. It is therefore likely that Groups 1-3 represent chronological phases, while variation amongst the subgroups may reflect social 
Table 2. Grave Groups at Huili Fenjiwan

\begin{tabular}{|c|c|c|c|c|c|}
\hline GROUP & $\begin{array}{l}\text { TENTATIVE } \\
\text { DATE }\end{array}$ & URN/JAR & OTHER CERAMICS & TOOLS & METAL \\
\hline $1 \mathrm{a}$ & $\begin{array}{l}\text { Early to } \\
\text { mid-5th c. }\end{array}$ & $\begin{array}{l}\text { 1-3 urns } \\
\text { and/or jars }\end{array}$ & No other ceramics & No tools & No metal \\
\hline $1 b$ & B.C. & $0-1$ jar & No other ceramics & 1 stone axe & No metal \\
\hline 1c & & $1-2$ jars & No other ceramics & $\begin{array}{c}1-2 \text { spindle } \\
\text { whorls }\end{array}$ & No metal \\
\hline 2 & $\begin{array}{l}\text { Late } 5 \text { th c. } \\
\text { B.c. }\end{array}$ & $\begin{array}{l}1-5 \text { urns } \\
\text { and/or jars }\end{array}$ & $\begin{array}{l}\text { Bowls, goblets, } \\
\text { ewers, vases, type } \\
\text { C single- or type } \\
\text { D or E double- } \\
\text { handled jar, cups; } \\
\text { up to } 12 \text { vessels }\end{array}$ & $\begin{array}{l}\text { 0-2 stone } \\
\text { ornaments } \\
\text { and/or } \\
\text { spindle } \\
\text { whorls }\end{array}$ & No metal \\
\hline $3 a$ & $\begin{array}{l}\text { Early 4th c. } \\
\text { B.C. }\end{array}$ & $0-1$ jar & No other ceramics & No tools & $\begin{array}{l}\text { 1-2 bronze objects } \\
\text { (bracelets, finger } \\
\text { rings, other metal } \\
\text { ornaments) }\end{array}$ \\
\hline $3 b$ & & $\begin{array}{r}0-3 \text { urns } \\
\text { or jars }\end{array}$ & $\begin{array}{l}\text { 1-2 goblets, ewers, } \\
\text { type I single- } \\
\text { handled jars, dou, } \\
\text { or bowls }\end{array}$ & $\begin{array}{c}0-1 \text { stone } \\
\text { arrows }\end{array}$ & $\begin{array}{l}\text { 1-5 bronze objects } \\
\text { (bracelets, } \\
\text { ornaments, swords, } \\
\text { spears, yue axes) }\end{array}$ \\
\hline $3 c$ & & $\begin{array}{r}1-2 \text { urns } \\
\text { or jars }\end{array}$ & $\begin{array}{l}1 \text { dou or single- } \\
\text { handled jar of } \\
\text { type I }\end{array}$ & $\begin{array}{c}\text { 0-1 spindle } \\
\text { whorls }\end{array}$ & No metal \\
\hline
\end{tabular}

differentiation. Based on parallels with objects from neighboring regions, Group 1 can be dated to the early to mid-fifth century B.C., Group 2 to the late fifth, and Group 3 to the early fourth century B.C.

Farther south, Xiaoyingpan and Xiaotuanshan in Huili County and Luquan Yingpanbao in Panzhihua City are characterized by small, near-empty slate graves, a few of which contain large jars similar to finds from Yongdingzhen in Yunnan (Chuxiong and Yunnansheng 1986: fig. 6) and from Fenjiwan Group I (Fig. 7.38-42). Narrownecked vases are known from the three sites and Yongdingzhen, but not from Fenjiwan, indicating an early local tradition.

The ceramics of Huili Leijiashan M1 are even more distinctive. They are highfired, fine-paste wares with surface decorations very different from the low-fired, coarse ceramics with limited decorations otherwise typical for the southeast (Fig. 7.17-30). Some of the vessels (moderately decorated, single-handled jars, vases, and goblets) resemble objects from Fenjiwan and both sites share the custom of placing flat river cobbles into the graves. The jars with ear-shaped handles seen at Leijiashan as well as Fenjiwan resemble objects from Yuanmou Dadunzi and other Late Neolithic to early Bronze Age sites in southern Yunnan (Yunnansheng 1977: fig. 17.6). These goblet forms also resemble objects from Phase IIa megalithic graves, and the stout single-handled jars with leaf-vein impressions on the bottom are not unlike objects from Phase IIb megalithic graves. Huili Miaozi Laobao finds are nearly identical with 
those from Leijiashan M1; ceramics from both sites likely date to around the third century B.C.

The graves of Huili Guojiabao contain high-fired fine ware as well, but the forms and decorations differ substantially from those at Huili Leijiashan (Fig. 8.1-39). Guojiabao's grave assemblages are characterized by single- and double-handled vessels accompanied by turquoise beads, bronze buttons, and other ornaments similar to those from the megalithic graves of Dechang Arong. Large numbers of bronze weapons and ornaments are nearly identical with finds from the Yanyuan Basin northwest of Huili. The bronze bracelets and some of the weapon types seen at Huili Guojiabao and in Yanyuan are commonly found in stone-construction graves throughout Southwest China. Belt hooks and scabbard tips at Huili Guojiabao and in Yanyuan are reminiscent of finds from stone-cist graves in northwest Sichuan (Aba and Lixian 1987; Sichuansheng et al. 1999). Rabbit-head-shaped bronze ornaments also appear in earth-pit graves (with or without stone installations) in Yunnan (Yunnansheng 2005). All of these comparanda date between the fourth and the first centuries B.C., as do findings from Dechang Arong. Therefore, Guojiabao and the finds from the Yanyuan Basin are dated to the same period.

Deposits in the Huili sites of Guoyuan, Luoluochong, and Zhuanchangba likewise contain objects completely different from any other finds in southeastern Liangshan (Huilixian 1977; Tao and Zhaodian 1982). Guoyuan and Luoluochong furnished one Shizhaishan-type bronze drum each. The form, quality, and material composition of these two drums identify them as imports from Yunnan dating to the third to the second century B.C. (Zhongguo 1988:37-47). A set of six bianzhong 編鐘 bells found at Zhuanchangba have no exact parallel anywhere else, and their mode of deposition is also unique. Sets of bells are found in graves in many parts of China, but separate or single deposits are uncommon. Within the research area, only Yanyuan Laolongtou M4 contained a bianzhong bell that did not come in a set. Using sets of bells as a musical instrument was common in the Central Plains, but likely unknown here. Bells of similar form have been found in great numbers throughout Yunnan, Guangxi, Guangdong, and northern Viet Nam (Falkenhausen 1988:561-563), but the decoration and metal composition of the Zhuanchangba bells identify them as a local product (Hein 2013:497-500). The bells from Zhuanchangba likely date to the first century A.D.

Evidence to the west of Huili in Panzhihua is so sparse that it is difficult to decide if the area is culturally connected to southeastern, western, or central Liangshan. Most available evidence comes from trapezoidal stone-construction graves arranged in neat rows in large cemeteries similar to graves in the upper Min River Valley. Only a single object from a grave at Yanyuan Yumen Wanxiao has been published: a stout jar with a high-narrow neck, wide shoulders, and ring handles strongly reminiscent of objects from Xichang Mimilang (Dukoushi 1986: fig. 2). ${ }^{4}$ Based on the parallels with Mimilang and the upper Min River area, graves at Yuman Wanxiao in Yanyuan can be dated tentatively between the seventh and the third centuries B.C.

\section{NORTHWESTERN LIANGSHAN: MULI, NINGLANG, AND YANYUAN}

Two major subsections can be distinguished in the northwestern part of the research area: the high-altitude mountains of Muli constitute one section and the Yanyuan Basin and its surrounding mountains (including Ninglang) the other. Very little 


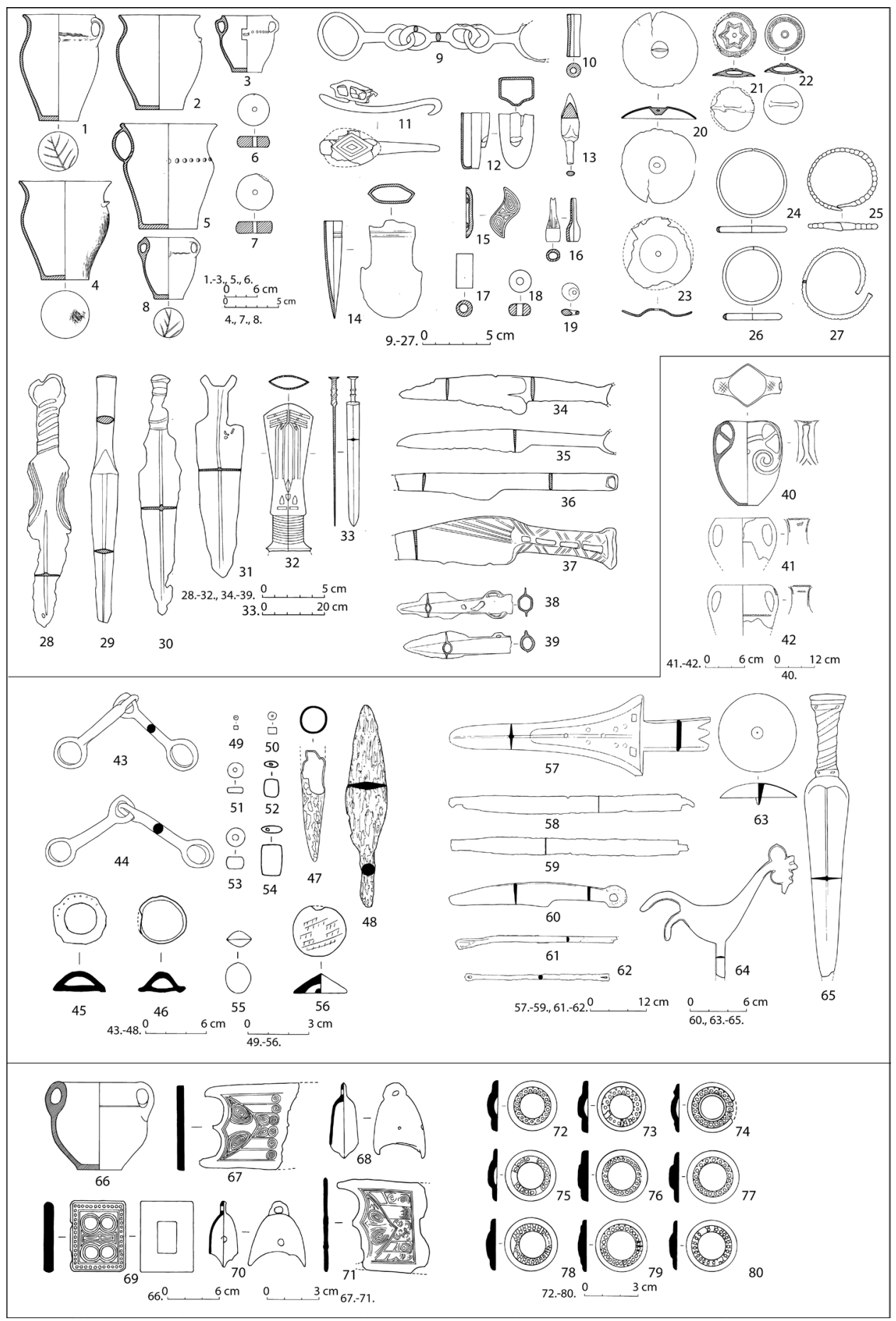

Fig. 8. Ceramics and bronze objects from the Northwest and Southeast: 1-39 from Huili Guojiabao (after Chengdu 2010: figs. 4-10); 40-65 from Yanyuan Laolongtou M4 (after Liangshan and Chengdu 2009: fig. 4-6); 66-80 from Yanyuan Laolongtou M9 (after Liangshan and Chengdu 2009: figs. 18, 19). 
research has been conducted in the entire northwest area, so our understanding of these subsections is patchy. The only sites reported from northwest Liangshan are Muli Qingrenbao and Shaoxiang Liangzi (Sichuansheng et al. 2012). The stone building observed at Qingrenbao is unique to the research area, but similar structures have been found at a small number of sites in Yunnan, northwest Sichuan, and Tibet (Aba et al. 2005; Sichuan et al. 2007; Sichuansheng and Ganzi 1998; Sichuansheng et al. 2003; Xizang and Sichuan 1985; Ya'an 1992; Yunnansheng, Dalizhou, and Jianchuanxian 2009). The dates for these buildings range widely from around 2000 B.C. to A.D. 100, but the foundations at Qingrenbao are most similar to features at the Dingdong Juzhu site in western Tibet, which dates to the fifth to the second century B.C. The ceramics found at Muli Qingrenbao and Shaoxiang Liangzi are largely identical in quality, form, and decoration, comprising jars with small band handles, vessels with flat horizontal grips, and jars with outward-flaring openings (Sichuansheng et al. 2012: fig. 6). The handled vessels resemble finds from Yanyuan as well as Deqin in northern Yunnan dating to the fourth to the first centuries B.C., suggesting a similar date for sites in Muli.

Settlement finds like this are rare in the northwestern area. The majority of objects reputedly from the western mountains were retrieved from the art market. A comparison of art-market finds with provenienced finds demonstrates that most of them came from local graves, but some items of foreign origin were also present among art-market finds and in local graves (Hein 2014b). ${ }^{5}$ The finds from Yanyuan in particular show an astonishing combination of various outside connections and local particularities. The elongated double-handled jars and small single-handled cups from Ninglang Daxingzhen are similar to objects found at Dechang Arong and other sites belonging to Phase IIIb of megalithic graves (Yunnansheng 1983b: figs. 5, 6). On the other hand, the combination of metal objects (including swords with three-pronged and torqued hilts, axes, ring-shaped pommel knives, spearheads with side loops, and mirrors) is virtually identical with grave assemblages from Deqin Yongzhi in Yunnan (Yunnansheng 1975). The sword types and mirrors are common to stone-cist graves on the upper Min River and occur even more often in northern Yunnan, particularly in Deqin and Chuxiong (Aba and Chengdu 2009). All of the comparanda date between the fifth and the first centuries B.C., but considering the parallels with Arong and lack of composite weapons or Han-type vessels, Ninglang Daxingzhen may fall into a narrower window of the fourth to the third century B.C.

Various types of double-handled vessels with a double-spiral motif occur at Ninglang Daxingzhen, in stone-cist graves along the upper Min River Valley, at Deqin Yongzhi (Yunnansheng 1975: figs. 4, 5), and in grave M4 at Yanyuan Laolongtou (Fig. 8.40). The subtype most similar to the vessels from Laolongtou M4 date to the second to the first century B.C. A drum and bell found in Laolongtou M4 are similar to third- to second-century B.C. objects from the Shizhaishan site in Northwest China, but the iron spearheads resemble objects from Phase IV megalithic graves at the Kunming Yangfutou site in central Yunnan, suggesting a slightly later date (Yunnansheng et al. 2005). Yanyuan Maojiaba M1 and M2 both held Shizhaishan-style drums, but the drum in Maojiaba M2 was associated with a composite weapon and an iron spear similar to the one in Yanyuan Laolongtou M4, while Maojiaba M1 was devoid of iron objects. Maojiaba M2 is likely contemporaneous with Laolongtou M4, but Maojiaba M1 dates earlier. 
The surface finds from Yanyuan Caojiawan resemble the Yanyuan Laolongtou M4 assemblage, suggesting a similar date. Laolongtou M11 furnished a different type of spearhead accompanied by a dagger with a fish-tail handle. This dagger type has parallels in Laolongtou M7, Deqin Nagu in Yunnan (Yunnansheng 1983), and several sites in northwest Sichuan (Baoxingxian 1982). Laolongtou M7 and M11 likely date between the second and the early first centuries B.C. The rich assemblages from Laolongtou M6 and M9 are very similar to each other, suggesting close dates. They both contain stout double-handled vessels quite different from those in M4, but similar to objects from Phase III megalithic graves. Similarities with objects from Maojiaba M1 further suggest that Laolongtou M6 and M9 date to the early second c. B.C.

\section{SOUTHWESTERN LIANGSHAN: YONGSHENG DUIZI AND ITS SURROUNDINGS}

The only extensively excavated (but unfortunately unpublished) site in the far southwestern part of the research area is Yongsheng Duizi. The site has thick cultural layers with settlement finds and various types of graves that excavators assigned to four separate phases. The earliest phase is represented by the settlement remains of Layer 4, the second by earth-pit graves and house remains, the third by the settlement remains of Layer 3, and the fourth by various stone-construction graves, cremation burials in urns, and earth-pit graves. ${ }^{6}$ Based on comparisons with finds from other sites, Duizi seems to have been occupied over a long period from around 2000 B.C. to 200 B.C. or later, but the internal chronology shows some gaps.

The gray sand-tempered ceramic vessels with wide openings and fine-corded ware, net patterns, or sometimes finger-tip-impressed appliqué bands from the earliest phase at Layer 4 are accompanied by stone woodworking tools and bone needles. These assemblages resemble finds from Yunnan such as at Yongping Xinguang (Yunnansheng et al. 2002) and Yuanmou Dadunzi (Yunnansheng 1977) dating to 2000-1700 B.C. The second phase earth-pit graves provided ceramics (i.e., gray polished and blackslipped fine ware with fish-bone patterns or incised lines, mostly stout jars, some with handles, carinated bowls, and wide-bellied vases) that are very similar to objects from the early Bronze Age (1200-900 B.C.) layers of Dali Yinsuodao in Yunnan (Yunnansheng, Dalizhou, and Jianchuanxian 2009). The second phase of Yongsheng Duizi likely dates to the same period, as does the third phase, which is characterized by undecorated sand-tempered pottery jars, basins, stemmed bowls, and a considerable number of crescent-shaped double-perforated knives. Such knives are common in early Bronze Age sites in Yunnan such as Jianchuan Haimenkou (Yunnansheng 1958) and Yinsuodao. The fourth phase earth-pit graves contain stemmed bowls resembling objects from Kunming Yangfutou (Yunnansheng et al. 2005) and other cemeteries around Lake Dian in Yunnan.

The stone-construction graves furnished double-handled jars with middle ribs in the handles similar to ceramics from Yanyuan Laolongtou M4 but in a more elongated form. The fourth phase graves share other object forms with the graves in Yanyuan, including composite weapons, ring-pommel knives, mirrors, 鈴 ling bells, cowrie shells, turquoise beads, and specific arrowhead forms. Based on these parallels, the fourth phase at Yongsheng Duizi can be dated to the late second to the early first century B.C. The gap between the third and fourth phases is puzzling, but as the material from Duizi still awaits publication, internal chronology is difficult to assess. 
Apart from Yongsheng Duizi, settlement sites in southwestern Liangshan are only known through surface finds that are insufficiently published and cannot be securely dated. Much further field research is needed before secure dates can be assigned.

\section{PREHISTORIC CULTURAL DEVELOPMENTS IN SOUTHWEST SICHUAN}

Based on the evidence from stratigraphy, typology, and radiocarbon dates described above, it finally becomes possible to compile a comprehensive chronological table for the Liangshan region, including southwestern Sichuan and adjacent parts of Yunnan (Table 3). As noted above, this region that has been disregarded because of its overall patchy data and the lack of an established chronological framework. Table 3 will therefore serve as a basis for sketching past cultural developments in this region.

\section{Southeastern Liangshan: Earliest Habitations and Local Particularities}

The earliest traces of human occupation in southwest Sichuan have been identified in the caves and early open-air sites of Huili and Panzhihua. Judging by the stonetool assemblages, their makers practiced a hunter-gatherer lifestyle and used caves and open-air sites as seasonal stations or hunting camps. Non-agricultural forms of subsistence may have continued among later groups who had begun producing ceramics. The local environment likely contributed to the emergence and potential persistence of these groups of hunter-gatherers. Specifically, Panzhihua is dominated by a mountainous terrain that is not conducive for agriculture, but is extremely rich in plant and animal species; its subtropical climate would have allowed people to practice this form of subsistence year-round (Hein 2015).

By contrast, places in the fertile valleys of Huili such as Yangjia Wuji and Houzidong became home to early agriculturalists (Hein 2015). The ceramics of these sites show strong local particularities, but the stone tools resemble finds from Yunnan. This connection with places farther south continues through later periods. Assemblages similar to finds from Houzidong were reported from numerous other sites in Huili, reflecting the existence of a local cultural group practicing incipient agriculture. The somewhat coarser assemblage from Houzidong likely reflects an earlier phase of this development.

Ceramics belonging to the same tradition also appear in slightly later stone graves at Yingpanbao in Luquan County and the Huili sites of Guantianshan/Yingpanshan, Xiaotuanshan, and Xiaoyingpan. ${ }^{7}$ Stone installations in graves are common throughout all of Southwest China, but the specific form of stone-cist grave construction and the associated burial rituals observed at these sites are locally specific. A limited amount of stone installations remain common in southeast Liangshan up to the time of Huili. What happens during the phase between the early stone-construction graves and the later earth-pit graves with or without stone installations found at Fenjiwan and other sites is not quite clear. The settlement site of Huili Dongzui is the only known site falling into this time period. Mode of subsistence, stone-tool assemblages, and ceramic quality at Dongzui continue earlier local traditions, but some of the ceramic forms bear resemblance to objects from Dechang Wangjiaping in the Anning River Valley. From this point onward, the southeastern area becomes integrated into developments in other parts of the research area. 
Although, as discussed above, connections with Xichang can be observed in the ceramic assemblage of the large cemetery and settlement site of Huili Fenjiwan (Hein $2014 a$ ), its burial customs were very different from the megalithic-grave tradition of the Anning River Valley. They show continuity with earlier local traditions, however. All graves at Fenjiwan are small and sparsely equipped. They contain very few ceramics and only rarely a single weapon, tool, or ornament made of stone or metal. The form and content of all the graves are similar, indicating that any differences between various subgroups of the population did not affect how they were buried. The large number of objects found in the single grave of Leijiashan M1 indicates that these egalitarian burial customs changed during post-Fenjiwan times.

The ceramic forms at Huili Leijiashan and Huili Miaozi Laobao mostly hail back to Fenjiwan. By contrast, the nearly contemporaneous graves of Huili Guojiabao furnish a completely different assemblage, with few ceramics and a large number of metal objects nearly identical to finds from Yanyuan. These graves likely held the remains of a small group of people who had come from Yanyuan, perhaps to facilitate trade between the two places (Hein 2014b). Otherwise, metal objects remain rare in graves in southeastern Liangshan. The stone molds found at Huili Washitian show that rich local metal resources were exploited, but metal production techniques remained rudimentary. High-quality foreign objects such as the drums deposited at Huili Guoyuan and Luoluochong were not emulated or at least not deposited in the ground.

Although the drums were apparently highly valued, metal does not seem to have played a significant role in defining cultural or personal identities in the grave context. In this, as in many other respects, southeastern Liangshan remained remarkably resistant to outside influence. The area went through its own course of development. The explanation for this probably lies in geographic preconditions. The area is highly fertile. It had ample natural resources that likely attracted early inhabitants from Yunnan to move north. The later Xichang influences on local ceramic traditions show that people from the Anning River Valley also migrated southeast. The central valley is an attractive place to settle, but metal resources are scarce there. The uneven distribution of natural resources may have been a decisive factor linking the various subregions closer together over time.

\section{The Anning River Valley: Thoroughfare and Center of Development}

Major developments in the Anning River Valley around 2500 B.C. seem to stem from the centrality of its location. Early sites with microlithic assemblages and coarse ceramics are mainly observed at the southern end of the valley, closer to Huili. The early settlements of the central area are dominated by similar coarse-stone tools reflecting a mixed economy. The shallow single layers of the settlements indicate shifting habitation. Minor differences in tool assemblages between various sites around Xichang reflect slightly different modes of subsistence, with some groups relying heavily on fishing and others on agriculture or hunting (Hein 2015). Differences in ceramic decoration between the central valley (Xichang), the northern end of the river (Mianning), and areas south (Dechang, Miyi, and Yanbian) reflect the existence of at least three separate production traditions, presumably associated with distinct groups. The differences in tool assemblages further indicate that communities toward the south maintained a mixed form of economy, while adopting most of the ceramic 


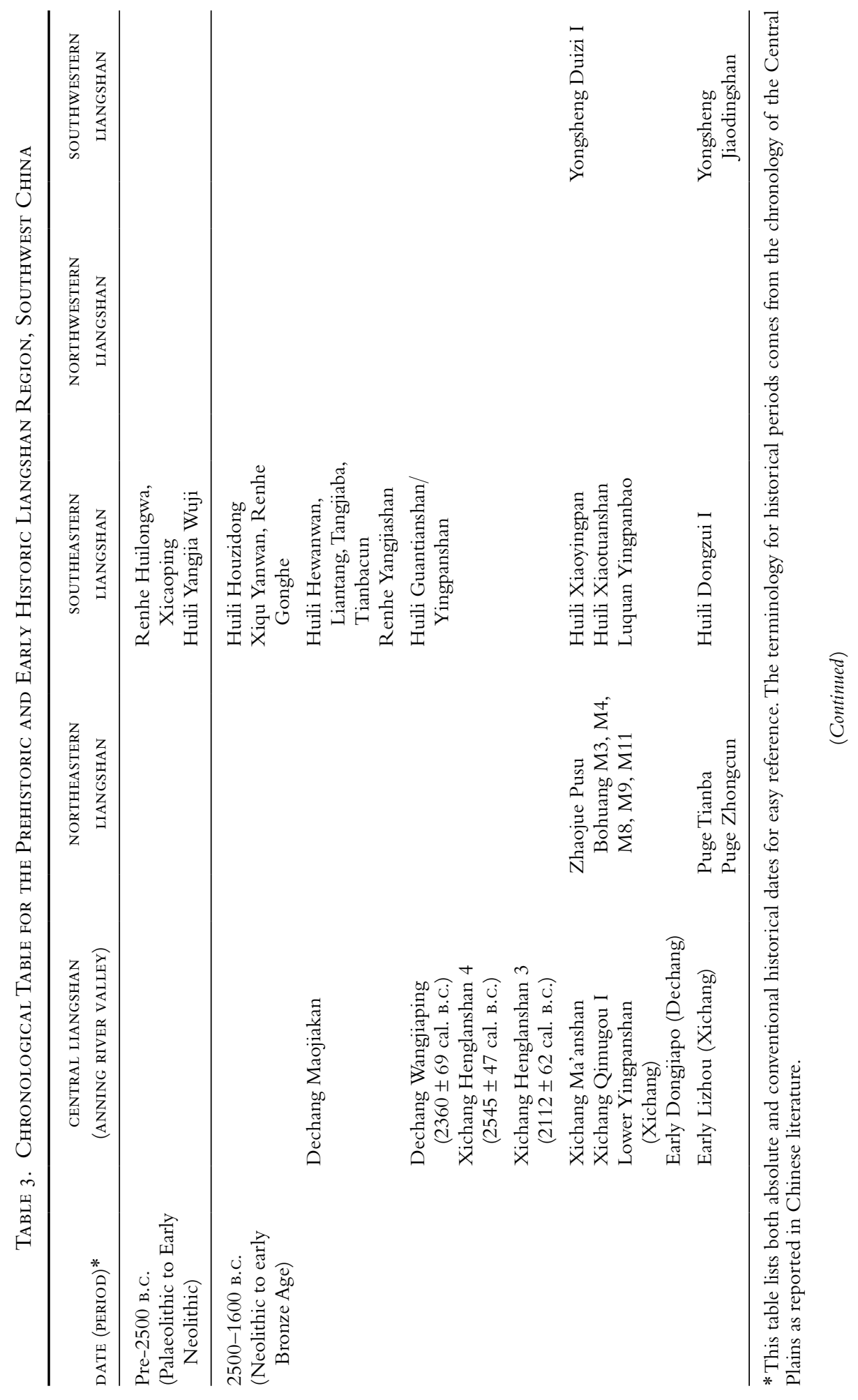




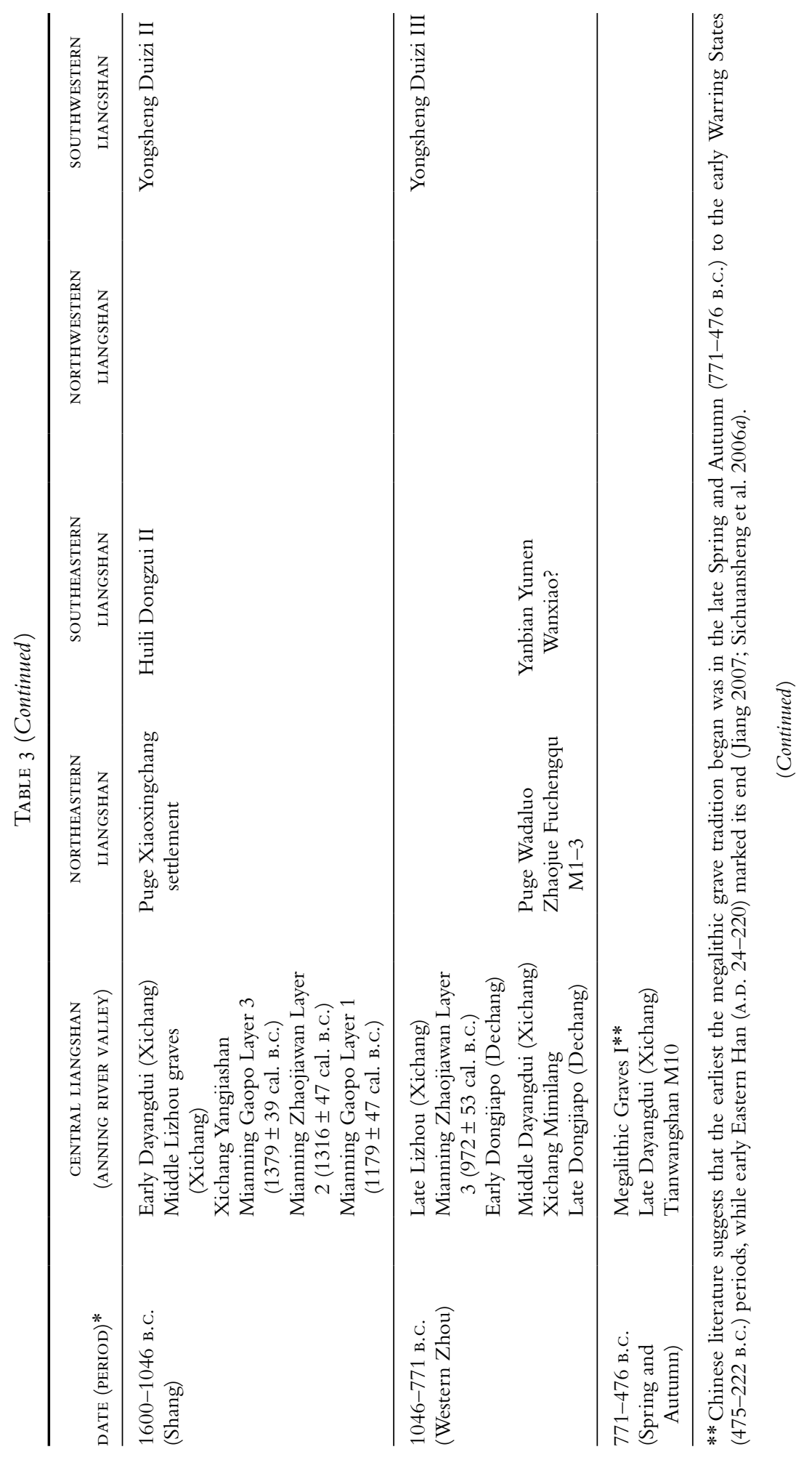




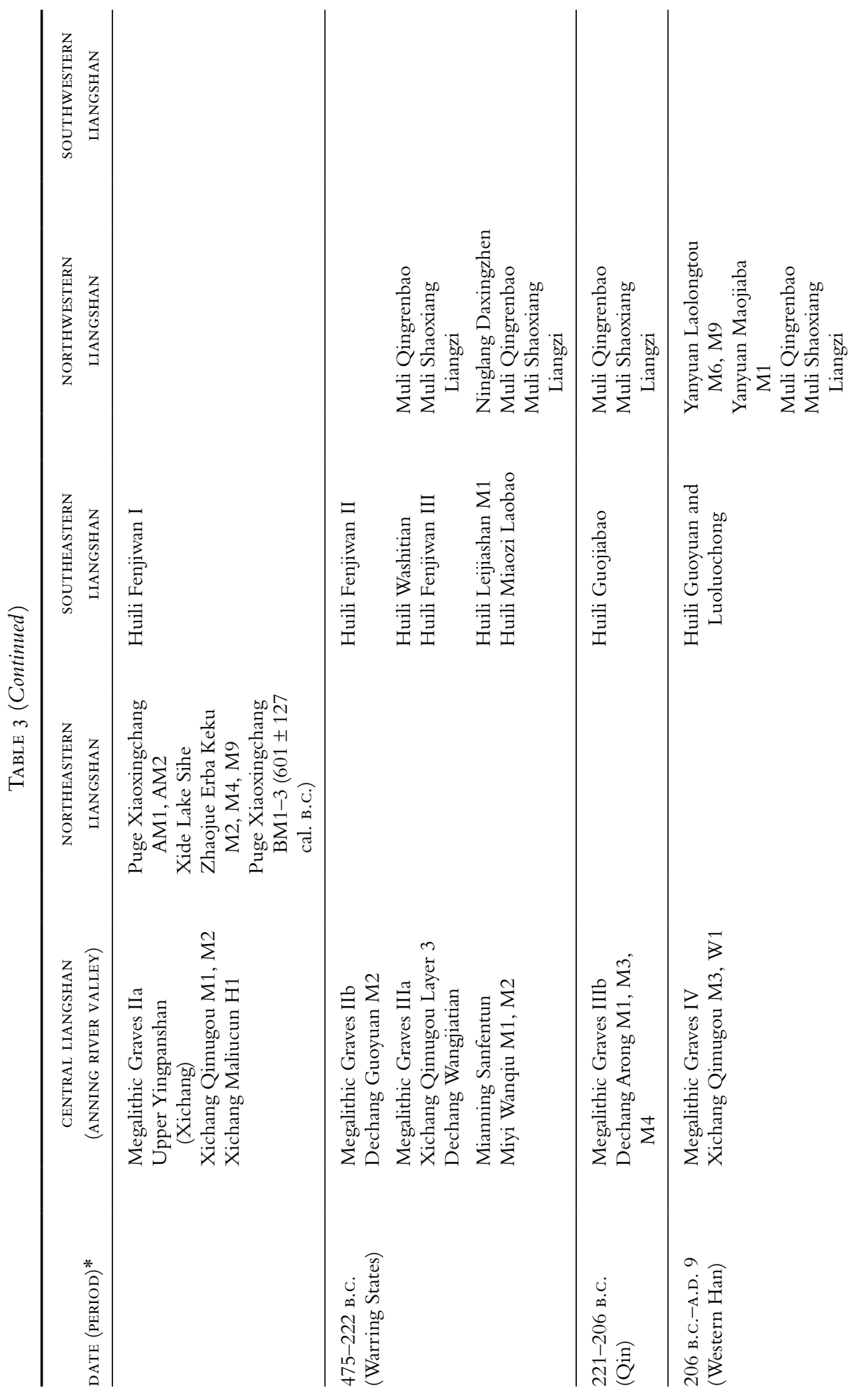

 


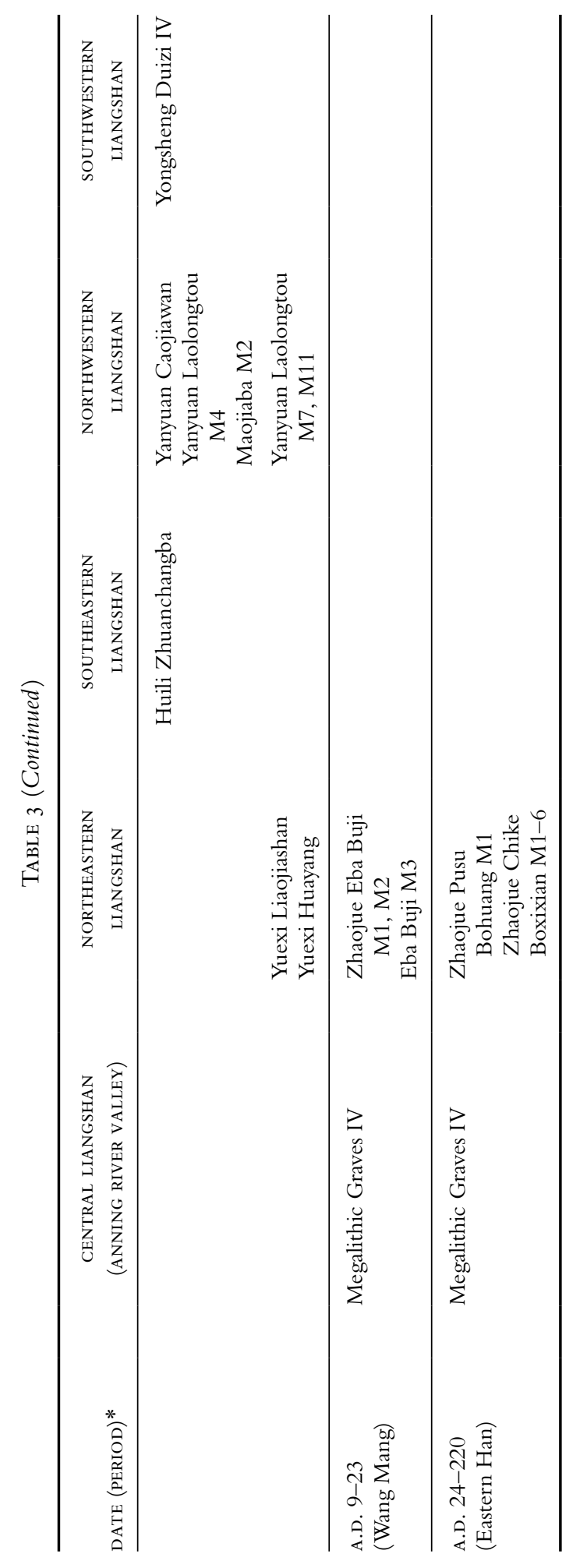


traditions common in the central valley, that is, ceramic traditions developed around the Anning River Valley and spread both north and south. In Mianning, only the inhabitants of Gaopo and Zhaojiawan produced a completely different ceramic assemblage, indicating that they had a separate and possibly foreign identity. Their descendants either left the area or were assimilated into local groups without their own ceramic tradition, leaving considerable traces in the later local material.

Similarities in ceramic assemblages between Hanyuan in northern Sichuan and Yuanmou in northern Yunnan demonstrate that the Anning River Valley served as a north-south transit corridor in southwest Sichuan (Hein 2013). Within this central corridor, outside influences can be seen from the time of Xichang Lizhou onward, when double-handled vessels resembling those from Qijia cultural traditions became common. Xichang Qimugou revealed high-fired ceramic vessels and metal objects so similar to objects from Gansu and Qinghai that a direct strong connection between these areas is very likely. Over time, local ceramic production techniques resulting in unevenly fired reddish-brown ware dominated, but the foreign double-handled forms remained.

Various groups inhabiting the Anning River Valley became increasingly integrated with the emergence of megalithic graves. Before, single primary interments with limited numbers of ceramic vessels in earth-pit graves had been the norm. Then the first small aboveground stone graves used in single instances of interment were built in Xichang. Although they were not reopened, pits containing sets of drinking vessels and ewers show that post-burial rituals must have taken place around them. Over time, these graves grew in size and began to be reopened for successive instances of primary interment. Some graves were entered to sort the bones or conduct other rituals. Drinking rituals also took place in or around the graves, as the sets of ceramics at grave entrances show. Processions between these graves, which were arranged in clusters highly visible in the landscape, may have taken place as well (Hein 2017).

This conspicuous custom of erecting and using megalithic graves in increasingly elaborate rituals spread south and north from the central valley, expanded into the eastern mountains of Puge and Xide, and probably reached northernmost Mianning sometime between the fourth and third centuries B.C. (Phase III for megalithic graves). At the same time, the ceramic material at local settlement sites such as Mianning Sanfentun changed drastically, becoming identical to what is known from megalithic graves at Xichang. The same applies to sites south of Xichang, where local forms were replaced by ceramics identical to those in Xichang.

Puge's megalithic graves somewhat differ from Xichang's in form and associated rituals, however. They are smaller, possibly because of the lack of flat ground in the eastern mountains. Their assemblages include bovine teeth used as ornaments and arrowheads as weapons instead of the bracelets, earrings, knives, and sharpening stones known from megalithic graves in the Anning River Valley. The earlier finds from Puge also demonstrate distinct local particularities in ceramic quality and form. The stone-tool assemblages observed at Puge's settlement sites suggest a strong reliance on hunting and, to a lesser extent, fishing, that is, the subsistence patterns were sensible adaptations to the densely forested local mountains. Their different ceramics furthermore shows that Puge inhabitants were likely culturally different from the inhabitants of the Anning River Valley. The differences continue into later phases in spite of the shared custom of erecting megalithic graves. 
Men and women of all ages were buried in megalithic graves in the Anning River Valley and the eastern mountains, but infants were not. The urn pits in Xichang at Yingpanshan and Qimugou may have been used for child burials by the same people who built the megalithic graves. The earth-pit graves Qimugou M1 and M2 are equipped with assemblages exceedingly like those in Phase IIa megalithic graves, suggesting that part of the adult population was also buried separately for unknown reasons.

As far as daily life is concerned, the tool assemblages from megalithic graves and related settlements in the central valley show a probably settled mode of living dependent on agriculture, supplemented by hunting and in some places fishing. Only the sites in Puge show a continued primary reliance on hunting. Metal seems to have mainly been used for personal ornaments and only secondarily weapons or tools. So far, no traces of local metalworking have been found, but the coarse quality and considerable number of metal ornaments indicate that they were locally produced. Copper could have been mined locally, but the tin must have come from places south of the Anning River Valley such as Huili, elsewhere in Yunnan, or even as far away as Southeast Asia. The same applies to other parts of the research area where no local tin sources have been reported.

\section{The Remote Mountains of Northeastern Liangshan: A Place Between}

Although technically located in northeastern Liangshan, Puge and Xide have a relatively moderate climate and less forbidding elevation compared to Zhaojue, Meigu, and Yuexi, which are located in very cold, remote mountains. The few known settlement remains and small number of tools found in graves in the far northeastern area suggest that hunting was an important subsistence practice. Woodworking tools and teeth of domesticated pigs have also been found in graves in the area, so mixed forms of economy were probably common (Hein 2015).

The great diversity of grave forms occurring in close vicinity to each other is particularly striking; assemblages combine objects from different traditions. Some imitate Han brick graves, while others resemble small megalithic graves, but all contain calcinated ropes (a particular local custom) next to Han imports and ceramics reminiscent of finds from Puge and even Huili. In spite of the noticeable continuities visible in some graves, the slight spatial separation between differently constructed graves within the same cemetery indicates that they were probably built for and by people belonging to different cultural groups. The considerable number of imported objects or objects showing foreign influence further identifies northeast Liangshan as a meeting point for goods and peoples of different origin. Who these people were and why they entered the area remain to be investigated.

The sizable number of Han objects in later graves in Zhaojue and Meigu and the appearance of Han brick graves are easier to explain. The Han were trying to find a way into and through the Liangshan region toward Yunnan. They seem to have settled the area in increasingly large groups, leaving traces of Han culture in their burial monuments and influences on local customs.

The case of Yuexi is less clear because only preliminary survey work has been conducted in the area. Various kinds of stone-construction graves, earth-pit graves, and even megalithic graves have been reported there. The objects found in Yuexi so far are 
similar to finds from Han-period stone-cist graves around the upper Min River. These finds confirm that northeastern Liangshan was a transit area where people from many different places met. How they interacted with each other and with the local population can only be determined through further fieldwork.

The High-Altitude Mountains, Plateaus, and Valleys of Western Liangshan: A Different World

Three different ethno-geographic entities can be distinguished in the western mountains of Liangshan. The wide, fertile, high-altitude valleys of Yongsheng have deeply layered settlement sites, while the high-altitude Yanyuan Basin and surrounding mountains of Yanyuan and Ninglang are dominated by various types of graves with stone installations and weapon-rich assemblages. Finally, remarkable stone houses were built on high mountaintops in Muli.

Some of the settlement sites in Yongsheng were used over a considerable time by a population relying mainly on agriculture for their subsistence (Hein 2015). Their burial customs were diverse and changed over time. The assemblages of its inhumation graves are dominated by ceramics combined with a few simple personal ornaments, tools, and rare knives or arrowheads. Ceramics from all periods show strong connections to central Yunnan. Connections with communities farther north are likewise visible, but the likelihood of a link to the Anning River Valley is remote. The same applies to Yanyuan and Ninglang.

It is uncertain when the area around Yanyuan and Ninglang was first inhabited, but the few small single-layered settlement sites and stone-tool and animal-bone assemblages observed in graves and settlements suggest that agriculture played only a minor role in local economies and settlement locations shifted frequently, at least up to the Han period. The grave forms and object assemblages reflect close connections with northwest Sichuan, but local particularities prevail. The graves are dominated by weapons accompanied by some personal ornaments and one or two ceramic vessels each, the opposite of assemblages from Yongsheng. A few graves in the Yanyuan Basin are particularly rich, containing large numbers of imported objects next to local ones. The unevenness in material wealth probably reflects the dominance of an elite over a particular resource (likely salt) that allowed them to trade widely and be buried in grand style (Hein 2014b).

How Yanyuan and Ninglang developed over time is difficult to say, as all known finds cover a period of only about 200 years. The same applies to Muli, where only two prehistoric sites have been reported so far. The stone houses observed in Muli show a very close connection with developments in eastern Tibet and northwest Sichuan, both high-altitude locations with a harsh environment. The animal-bone assemblages in Muli are remarkable. They are dominated by deer and other wild species, while domesticated pig and cattle are rare. Bones of domesticated horses have also been found in Muli (Sichuansheng et al. 2012). Here we see an interesting connection with Yanyuan, where horse heads and long bones accompanied by horse gear were interred in some of the richest graves, reflecting the local importance of horses and horse riding. It remains to be seen if settlements similar to those in Muli will be found farther south and if graves similar to those in Yanyuan and Ninglang appear in Muli, or if the two places share subsistence systems and an emphasis on horse riding, but are otherwise culturally distinct. 


\section{CONCLUSION}

As the comparative analysis of material from the different kinds of sites has shown, there are remarkable discrepancies in archaeological assemblages between various subregions of the broader Liangshan region. The subsistence systems are clearly influenced by the particular environmental preconditions in each of the different subregions. In spite of local economic and cultural particularities, the various subregions were in constant contact and became increasingly interconnected over time. The conspicuous custom of building megalithic graves and conducting complex rituals in and around them seems to have attracted a considerable number of people from various cultural backgrounds throughout the Anning River Valley and beyond. Populations living in the remote northeastern mountains were not integrated into this development, but were influenced by peoples living farther south and east. Elements of foreign origin are so manifold, in fact, that it is currently difficult to say what specific local developments may have looked like. Further field research is badly needed before a long-term developmental sequence can be established for the northeastern area of Liangshan.

The southeastern area is considerably better understood than the northeast. People in this area developed quite independently of cultural developments in the Anning River Valley. Even though some elements of the stone-tool and ceramic assemblages reveal close connections with neighboring parts of northeastern Yunnan, the overall character of object forms is distinctive, as are the burial customs of the southeast. Later ceramics (from at least the seventh century B.C. onward) show that the southeastern area was not completely isolated from the Anning River Valley, however, and ceramics in the northeastern area show that interactions between the northeastern area and the southeastern area of Liangshan commenced even earlier. The graves of Huili Guojiabao even suggest that people from the southwest may have relocated to southeast Liangshan, but local object production and burial customs seem to have remained remarkably unchanged by such external influences.

The western mountains of Liangshan are a very different case, but developments there are no more unified than in the southeast. The Yongsheng area is more closely integrated into broader cultural developments in Yunnan, but the rich variety of grave and interment forms practiced by apparently flourishing settled agricultural communities are so far unique even for northwest Yunnan. Here, again, further field research is needed to confirm if what we see at Yongsheng Duizi is a localized phenomenon limited to the area around Chenghai Lake.

The rich graves of the horse-riding warriors of Yanyuan and Ninglang are a rather short-lived but complex phenomenon that implies the peoples of the southwestern mountains were integrated into a wide-ranging exchange network. The combination of various foreign elements and local particularities is fairly unique to the area, so further fieldwork is needed before we can claim to understand the local origins of some of the peculiar later developments.

Northwestern Liangshan seems to be part of a cultural sphere spanning the southern rim of the Tibetan Plateau. That this cultural phenomenon expanded so far east is surprising, but further surveys and excavations will hopefully determine if the two sites discovered so far in the area are exceptions or representative examples of a wider local tradition. 
Overall, it has become clear that the Liangshan region was a meeting place for people from various parts of Western China and beyond, a transit region that incorporated vastly different cultural phenomena. Local archaeological material must be integrated into future studies on the prehistory of Sichuan and Yunnan or Western China in general.

The various ecological niches characterizing the Liangshan region led to the development of peculiar local cultural phenomena that are well worth studying in their own right. The chronological scheme and developmental sequences outlined in this article provide a basis for such studies. The chronology will undoubtedly be amended as newly excavated material becomes available and sequences of radiocarbon dates are systematically taken for all known sites.

In the absence of dates obtained through archaeometric research, this study has shown that traditional methods of typology and comparison, combined with an awareness of the importance of the natural environment and the wide variety of mechanisms of intergroup exchange, remain powerful tools in establishing prehistoric cultural developments within their temporal framework and natural environment. Furthermore, this article demonstrates that the Liangshan region was not a remote backwater, but rather a crucial intersection point between the northern steppe and the fertile plains of Yunnan and Sichuan. Understanding Liangshan is critical for establishing a chronology of Southwest China and writing the cultural history of the prehistoric Chinese border regions.

\section{ACKNOWLEDGMENTS}

Collecting the published and unpublished materials that are the basis for this article was possible only with the help of a considerable number of people. Most importantly, I want to thank Jiang Zhanghua 江章華 for introductions to archaeologists working in the Liangshan region and for our long and very fruitful discussions on local prehistoric cultural developments. I am also very much indebted to Liu Hong 劉宏, who generously granted me access to the original material held at the Liangshan Museum and made it possible for me to travel to many sites throughout the Liangshan region. And of course, none of this would have been possible without Sun Hua 孫華, who took me under his wing and introduced me to southwest Sichuan and its wonderful archaeology in the first place. Last but not least, I would like to thank the reviewers and the editorial team for their detailed comments and corrections that helped improve this article significantly. All remaining mistakes or lack of clarity are mine.

Appendix A: Overview of Source Material for Information on Sites IN LiANGSHAN REgION

\begin{tabular}{lcc}
\hline SITE & \multicolumn{1}{c}{ SOURCE } \\
\hline Liangshan Yi Autonomous Prefecture, Sichuan Province 四川省涼山彝族自治州 \\
Dechang Arong & 德昌阿榮 & Sichuansheng et al. 2006a, 2006d; Zhongguo \\
& 2009; data collection* \\
Dechang Ayong & 德昌阿雍 & Zhongguo 2009 \\
Dechang Ayue & 德昌阿月 & Sichuansheng et al. 2006a; Zhongguo 2009 \\
Dechang Cizhuiping & 德昌茨竹坪 & Zhongguo 2009 \\
Dechang Daba & 德昌大垻 & Sichuansheng et al. 2006a; Zhongguo 2009 \\
Dechang Dachangba & 德昌大敞垻 & Sichuansheng et al. 2006a; Zhongguo 2009
\end{tabular}


Appendix A (Continued)

\begin{tabular}{|c|c|c|}
\hline SITE & & SOURCE \\
\hline Dechang Dashipai & 德昌大石排 & $\begin{array}{l}\text { Liu 2009; Sichuansheng et al. 2006a; } \\
\text { Zhongguo 2009; data collection }\end{array}$ \\
\hline Dechang Dianma & 德昌點馬 & Zhongguo 2009 \\
\hline Dechang Dongjiapo & 德昌董家坡 & Zhou 2011; data collection \\
\hline Dechang Fangjiacun & 德昌方家村 & Zhongguo 2009; data collection \\
\hline Dechang Ganhai & 德昌干海 & Sichuansheng 2006a; Zhongguo 2009; \\
\hline Dechang Guadi & 德昌瓜地 & data collection \\
\hline Dechang Guoyuan & 德昌果園 & $\begin{array}{l}\text { Sichuansheng et al. 2006a; Xichang } 1978 b \text {; } \\
\text { Zhongguo 2009; data collection }\end{array}$ \\
\hline Dechang Hejia Fenshan & 德昌何家墳山 & Sichuansheng et al. $2006 a$ \\
\hline Dechang Hejiashan & 德昌何傢山 & Zhongguo 2009 \\
\hline Dechang Hezui & 德昌何嘴 & Liu Hong 2009 \\
\hline Dechang Hongmiao & 德昌紅廟 & Sichuansheng et al. 2006a; Zhongguo 2009 \\
\hline Dechang Hongmiaocun & 德昌紅廟村 & Zhongguo 2009 \\
\hline Dechang Huangjiaba & 德昌黃家垻 & Sichuansheng et al. 2006a; Zhongguo 2009 \\
\hline Dechang Liangsanpo & 德昌涼傘坡 & Sichuansheng et al. 2006a; Zhongguo 2009 \\
\hline Dechang Luojiaba & 德昌儸家堡 & $\begin{array}{l}\text { Sichuansheng et al. 2006a; Zhongguo 2009; } \\
\text { data collection }\end{array}$ \\
\hline Dechang Ma'anzi & 德昌馬鞍子 & Sichuansheng et al. 2006a; Zhongguo 2009 \\
\hline Dechang Maliliang Zhanbei & 德昌麻栗糧站北 & Zhongguo 2009 \\
\hline Dechang Maliliang Zhannan & 德昌麻栗糧站南 & $\begin{array}{l}\text { Sichuansheng et al. 2006a; Zhongguo 2009; } \\
\text { data collection }\end{array}$ \\
\hline Dechang Maojiaba & 德昌毛傢垻 & Zhongguo 2009 \\
\hline Dechang Maojiakan & 德昌毛傢坎 & $\begin{array}{l}\text { Sichuansheng \& Liangshan 2007; data } \\
\text { collection }\end{array}$ \\
\hline Dechang Minzhucun & 德昌民主村 & Sichuansheng et al. 2006a; Zhongguo 2009 \\
\hline Dechang Nanhua Baobao & 德昌南華包包 & Sichuansheng et al. $2006 a$ \\
\hline Dechang Nanhuagong & 德昌南華官 & Zhongguo 2009 \\
\hline Dechang Shaba & 德昌沙垻 & Sichuansheng et al. $2006 a$ \\
\hline Dechang Shaorenba & 德昌燒人垻 & Sichuansheng et al. $2006 a$; data collection \\
\hline Dechang Shengli & 德昌勝利 & Sichuansheng et al. $2006 a$ \\
\hline Dechang Shuijingwan & 德昌水井灣 & Sichuansheng et al. $2006 a$ \\
\hline Dechang Shuitangcun & 德昌水塘村 & Sichuansheng et al. 2006a; Zhongguo 2009 \\
\hline Dechang Wangjiaping & 德昌汪傢坪 & Chengdushi et al. 2009 \\
\hline Dechang Wangjiatian & 德昌王家田 & $\begin{array}{l}\text { Sichuansheng \& Liangshan 2006; data } \\
\text { collection }\end{array}$ \\
\hline Dechang Wujia & 德昌吳傢 & Sichuansheng et al. 2006a; Zhongguo 2009 \\
\hline Dechang Xiaogao & 德昌小高 & Sichuansheng et al. $2006 a$ \\
\hline Dechang Xiaoliusuo & 德昌小六所 & Sichuansheng et al. $2006 a$; data collection \\
\hline Dechang Xiaomiaoshan & 德昌小廟山 & $\begin{array}{l}\text { Sichuansheng et al. 2006a; Zhongguo 2009; } \\
\text { data collection }\end{array}$ \\
\hline Dechang Xinmin Wujia & 德昌新民吳 & Sichuansheng et al. $2006 a$ \\
\hline Dechang Yingzipo & 德昌銀子坡 & Zhongguo 2009 \\
\hline Dechang Yongxing & 德昌永興 & Zhongguo 2009; data collection \\
\hline Dechang Yuejin & 德昌躍進 & Sichuansheng et al. 2006a; Zhongguo 2009 \\
\hline Dechang Zhangjiaba & 德昌張家垻 & Sichuansheng et al. 2006a; Zhongguo 2009 \\
\hline Huidong Dashanba & 會東大山包 & Zhongguo 2009; data collection \\
\hline Huidong Liujiawan & 會東劉傢灣 & Zhongguo 2009 \\
\hline Huili Dachonggou & 會理大沖溝 & Zhongguo 2009 \\
\hline Huili Dazhaizi & 會理大寨子 & Liu Hong pers. comm., 11/2010 \\
\hline
\end{tabular}

(Continued) 
Appendix A (Continued)

\begin{tabular}{|c|c|c|}
\hline SITE & & SOURCE \\
\hline Huili Dongzui & 會理東咀 & $\begin{array}{l}\text { Chengdu, Liangshanzhou, \& Huilixian 2008; } \\
\text { data collection }\end{array}$ \\
\hline Huili Fenjiwan & 會理粪箕湾 & $\begin{array}{l}\text { Huilixian et al. 2004, Sichuansheng et al. } \\
\text { 2009; Tang 1992; Zhongguo 2009; data } \\
\text { collection }\end{array}$ \\
\hline $\begin{array}{l}\text { Huili Gong'anju (aka } \\
\text { Huili94) }\end{array}$ & 會理公安局 (會理94) & Tang 1996 \\
\hline $\begin{array}{l}\text { Huili Guantianshan (aka } \\
\text { Yingpanshan) }\end{array}$ & 會理觀田山 & Sichuansheng et al. 2009; data collection \\
\hline Huili Guojiabao & 會理郭傢堡 & $\begin{array}{l}\text { Sichuansheng et al. 2009; Zhongguo 2009; } \\
\text { data collection }\end{array}$ \\
\hline $\begin{array}{l}\text { Huili Guoyuan (aka Huili } \\
\text { Drum 4) }\end{array}$ & $\begin{array}{l}\text { 會理觀果園師 (會理 } \\
\text { 四號鼓) }\end{array}$ & Tang 1998; data collection \\
\hline Huili Hedongtian & 會理河東田 & Data collection \\
\hline Huili Hekoucun & 會理河口村 & Tang 1993 \\
\hline Huili Hewanwan & 會理河灣灣 & Tang 1992 \\
\hline Huili Houzidong & 會理猴子洞 & $\begin{array}{l}\text { Sichuansheng et al. 2009; Zhongguo 2009; } \\
\text { data collection }\end{array}$ \\
\hline Huili Jinmei & 會理金梅 & Zhongguo 2009 \\
\hline Huili Kangzipo & 會理康芓坡 & Data collection \\
\hline Huili Leijiashan & 會理雷傢山 & $\begin{array}{l}\text { Chengdu, Liangshanzhou, \& Huilixian 2009; } \\
\text { Zhou et al. 2010; data collection }\end{array}$ \\
\hline Huili Liantang & 會理蓮塘 ～～～～～～～～ & Tang 1992; data collection \\
\hline $\begin{array}{l}\text { Huili Luoluochong (aka } \\
\text { Huili Drum 3) }\end{array}$ & $\begin{array}{l}\text { 會理羅羅沖 (會理三 } \\
\text { 號鼓) }\end{array}$ & Zhongguo 2009 \\
\hline Huili Miaozi Laobao & 會理廟子老堡 & Sichuansheng et al. 2009; data collection \\
\hline Huili Puling & 會理普隆 & Tang 1992; Zhongguo 2009 \\
\hline Huili Qiaoba & 會理喬垻 & Liu Hong pers. comm., 11/2010 \\
\hline Huili Raojiadi & 會理饒家地 & Data collection \\
\hline Huili Shenjiafen & 會理沈傢墳 & Zhongguo 2009 \\
\hline Huili Tangjiaba & 會理唐傢垻 & Tang 1992 \\
\hline Huili Tangjiapo & 會理唐傢坡 & Tang 1992; Zhongguo 2009 \\
\hline Huili Tianbacun & 會理田垻村 & Sichuansheng et al. 2009 \\
\hline Huili Washitian & 會理瓦石田 & $\begin{array}{l}\text { Sichuansheng et al. 2009; Tao 1981; } \\
\text { Zhongguo 2009; data collection }\end{array}$ \\
\hline Huili Wuhuangqing & 會理吳黃箐 & Tang 1999; Zhongguo 2009 \\
\hline Huili Xiao'aozi & 會理小凹子 & Zhongguo 2009; data collection \\
\hline Huili Xiaotuanshan & 會理小團山 & Tang 1999; Zhongguo 2009 \\
\hline Huili Xiaoyingpan & 會理小營盤 & $\begin{array}{l}\text { Kunmingshi et al. 2007; Sichuansheng et al. } \\
2009\end{array}$ \\
\hline Huili Xicaodi & 會理席草地 & Zhongguo 2009 \\
\hline Huili Yangjia Wuji & 會理楊傢屋基 & Zhongguo 2009 \\
\hline Huili Yimen Xiacunxiang & 會理益門下村飨 & Tang 1999 \\
\hline Huili Yingpanshan & 會理營盤山 & Zhongguo 2009 \\
\hline Huili Yuanbaoshan & 會理元寶山 & Zhongguo 2009; data collection \\
\hline Huili Yunshancun & 會理云山村 & Zhongguo 2009 \\
\hline Huili Zhuangchangba & 會理轉場垻 & Zhonggguo 2009 \\
\hline Meigu Azu Bugu & 美姑阿足 & Sichuansheng et al. $2006 a$ \\
\hline Meigu Jiukou Jiaogu & 美姑九口腳谷 & Sichuansheng et al. $2006 a$ \\
\hline Meigu Shengdu Wage & 美姑聖都瓦各 & Liu Hong pers. comm., 12/2010 \\
\hline Meigu Wagujue Cunnan & 美姑瓦姑覺村南 & Sichuansheng et al. $2006 a$ \\
\hline
\end{tabular}


Appendix A (Continued)

SITE

Meigu Wagujue Dongbei

Meigu Wagujue Dongnan

Mianning Beishanba

Mianning Chengguan

Mianning Gaopo

Mianning Gaopo Wanwan

Mianning Hujiacui

Mianning Manshuiwan

Mianning Miaoshan

Mianning Ruoshuicun

Mianning Sanfentun

Mianning Sankuaishi

Mianning Songlin Laojie

Mianning Wenjiatun

Mianning Xiangshi

Mianning Xiaogoudi

Mianning Zhaojiawan

Muli Qingrenbao

Muli Shaoxiang Liangzi

Ningnan Heinigou

Ningnan Tangjiawan

Puge Amucun

Puge Heping

Puge Kangli

Puge Tianba

Puge Tuantian

Puge Wadaluo

Puge Xiaoxingchang

Puge Zhongcun

Xichang Bahe Baozi

Xichang Baijiazhai

Xichang Beishan

Xichang Bengtukan

Xichang Changcun

Xichang Chenyuancun

Xichang Dabaobao

Xichang Dabaozi

Xichang Dacaoba

Xichang Damaliu

Xichang Daniba

Xichang Dashiban
美姑瓦姑覺東北

美姑瓦姑覺東南

冕寧北山垻

冕寧城関

冕寧高坡

冕寧高坡灣灣

冕寧胡家嘴

冕寧漫水灣

冕寧廟山

冕寧若水村

冕寧三分屯

冕寧三塊石

冕寧松林老街

冕寧文家屯

俛寧响石

莬寧小溝地

冕寧趙家灣

木里縣情人寶

木里縣燒香梁子

寧南黑泥溝

寧南唐傢灣

普格阿木村

普格和平

普格康利

普格田坝

普格團田

普格瓦打洛

普格小興場

普格中村

西昌垻河堡子

西昌白家寨

西昌北山

西昌崩土坎

西昌長村

西昌陳遠村

西昌大包包

西昌大堡子

西昌大草垻

西昌大麻柳

西昌大泥垻

西昌大石板
SOURCE

Sichuansheng et al. $2006 a$

Sichuansheng et al. $2006 a$

Sichuansheng et al. 2006a; Zhongguo 2009

Yang 2001

Data collection

Liu 2009; Zhongguo 2009; data collection

Liu 2009; data collection

Zhongguo 2009

Liu 2009; Zhongguo 2009; data collection

Sichuansheng et al. 2006a; Zhongguo 2009

Liangshan \& Mianningxian 2006; data collection

Sichuansheng et al. 2006a; Zhongguo 2009

Sichuansheng et al. $2006 a$

Liu 2009

Sichuansheng et al. 2006a; Zhongguo 2009

Zhongguo 2009

Chengdushi et al. 2012; data collection

Sichuansheng et al. 2012

Sichuansheng et al. 2012

Zhongguo 2009

Zhongguo 2009

Zhongguo 2009

Zhongguo 2009

Data collection

Liangshan et al. 1982

Liangshan et al. 1982

Liangshan 1983a; Zhongguo 2009; data collection

Liangshan \& Pugexian 1987; Liangshan et al. 1982; Sichuansheng et al. 2006a; Zhongguo 2009; data collection

Liangshan et al. 1982

Liu 2009; Sichuansheng \& Anninghe 1976; Sichuansheng et al. 2006a; Xichang et al. 1978; Zhongguo 2009; data collection

Sichuansheng et al. 2006a; Zhongguo 2009

Liangshan 1990; Sichuansheng et al. 2006a; Zhongguo 2009

Zhongguo 2009

Zhongguo 2009

Huang 2000; Liu \& Wang 2007; Zhao 1981

Zhongguo 2009

Sichuansheng et al. 2006a; Zhongguo 2009; data collection

Sichuansheng et al. 2006a; Zhongguo 2009

Zhongguo 2009

Liu 2009

Sichuansheng et al. 2006a; Zhongguo 2009; data collection

(Continued) 
Appendix A (Continued)

\begin{tabular}{|c|c|c|}
\hline SITE & & SOURCE \\
\hline Xichang Dayangdui & 西昌大洋堆 & $\begin{array}{l}\text { Sichuansheng et al. 2006a; Xichangshi et al. } \\
\text { 2004; Zhongguo 2009; data collection }\end{array}$ \\
\hline Xichang Dongping & 西昌東坪 & Jiang 1994; Sichuansheng et al. 2006e \\
\hline Xichang Dongyuemiao & 西昌東获廟 & Zhongguo 2009 \\
\hline Xichang Guanjiashan & 西昌官家山 & Zhongguo 2009 \\
\hline Xichang Guanshan & 西昌関山 & $\begin{array}{l}\text { Liangshan 1983b; Liu 2009; Sichuansheng } \\
\text { et al. 2006a; Zhongguo } 2009\end{array}$ \\
\hline Xichang Guihuacun & 西昌桂花村 & Sichuansheng et al. 2006a; Zhongguo 2009 \\
\hline Xichang Henglanshan & 西昌橫欄山 & $\begin{array}{l}\text { Chengdu et al. 2006; Xichangshi 1998; data } \\
\text { collection }\end{array}$ \\
\hline Xichang Hexi Gongshe & 西昌河西公社 & $\begin{array}{l}\text { Sichuansheng et al. 2006a; Xichang } 1978 c \text {; } \\
\text { Zhongguo 2009; data collection }\end{array}$ \\
\hline Xichang Hongqi & 西昌紅旗 & Sichuansheng et al. $2006 a$ \\
\hline Xichang Huangshuitang & 西昌黃水塘 & $\begin{array}{l}\text { Liangshan 1990; Sichuansheng et al. 2006a; } \\
\text { Zhongguo } 2009\end{array}$ \\
\hline Xichang Jiangjiabao & 西昌蔣傢包 & Zhongguo 2009 \\
\hline Xichang Jianxin & 西昌建新 & Sichuansheng et al. 2006a; Zhongguo 2009 \\
\hline Xichang Liguoshan & 西昌李果山 & Sichuansheng et al. $2006 a$ \\
\hline Xichang Lijiagou cun & 西昌李傢溝村 & Zhongguo 2009 \\
\hline Xichang Lizhou & 西昌禮州 & Huang 2000; Liu \& Wang 2007; Zhao 1981 \\
\hline Xichang Luzhuishan & 西昌盧嘴山 & Sichuansheng et al. 2006a; Zhongguo 2009 \\
\hline Xichang Ma'anshan & 西昌馬鞍山 & Chengdu et al. $2007 b$; data collection \\
\hline Xichang Mahuangkan & 西昌螞螾坎 & Liu 2009 \\
\hline Xichang Maliucun & 西昌麻柳村 & $\begin{array}{l}\text { Sichuansheng et al. 2006a, 2006b; data } \\
\text { collection }\end{array}$ \\
\hline Xichang Maomaoshan & 西昌帽帽山 & Sichuansheng et al. 2006a; Zhongguo 2009 \\
\hline Xichang Mimilang & 西昌咪咪啷 & $\begin{array}{l}\text { Liangshan et al. 2006; Sichuansheng et al. } \\
\text { 2006a; data collection }\end{array}$ \\
\hline Xichang Qimugou & 西昌棲木沟 & $\begin{array}{l}\text { Chengdu, Liangshanzhou, \& Xichangshi } \\
\text { 2008, 2009; Chengdushi et al. 2009; } \\
\text { Sichuansheng et al. 2006a, 2006c; data } \\
\text { collection }\end{array}$ \\
\hline Xichang Qujia Laokan & 西昌䝬家老坎 & Liu 2009 \\
\hline Xichang Reshuitang & 西昌熱水塘西 & Zhongguo 2009 \\
\hline Xichang Sanhe & 西昌三和 & Liu 2009 \\
\hline Xichang Shajiapo & 西昌沙家坡 & Sichuansheng et al. 2006a; Zhongguo 2009 \\
\hline Xichang Shangxiang & 西昌上香 & Zhongguo 2009 \\
\hline Xichang Shantou & 西昌山頭 & Liu 2009 \\
\hline Xichang Shaojia Gaokan & 西昌省傢高坎 & Liu 2009 \\
\hline Xichang Shijia Baozi & 西昌施傢堡子 & Zhongguo 2009; data collection \\
\hline Xichang Shizuizi & 西昌石嘴子 & Sichuansheng et al. 2006a; Zhongguo 2009 \\
\hline Xichang Shuanggudui & 西昌雙谷堆 & Sichuansheng et al. 2006a; Zhongguo 2009 \\
\hline Xichang Tanshan & 西昌墰山 & Zhongguo 2009 \\
\hline Xichang Tianbacun & 西昌田垻村 & Sichuansheng et al. $2006 a$ \\
\hline Xichang Tianwangshan & 西昌天王山 & $\begin{array}{l}\text { Liangshan 1984; Zhongguo Wenwu 2009; } \\
\quad \text { data collection }\end{array}$ \\
\hline Xichang Tuanbao & 西昌團堡 & Data collection \\
\hline Xichang Tuanshanbao & 西昌團山包 & Liu 2009; Zhongguo 2009 \\
\hline Xichang Tu'ershan & 西昌兔兒山 & Liu 2009 \\
\hline Xichang Wanao & 西昌窪堖 & $\begin{array}{l}\text { Sichuansheng et al. 2006a, 2006d; Zhongguo } \\
\text { 2009; data collection }\end{array}$ \\
\hline
\end{tabular}


Appendix A (Continued)

\begin{tabular}{|c|c|c|}
\hline SITE & & SOURCE \\
\hline Xichang Wuguishan & 西昌鳥龜山 & Sichuansheng et al. 2006a; Zhongguo 2009 \\
\hline Xichang Xiaohuashan & 西昌小華山 & $\begin{array}{l}\text { Liangshan 1990; Sichuansheng et al. 2006a; } \\
\text { Zhongguo } 2009\end{array}$ \\
\hline Xichang Xiaojia Gaokan & 西昌省傢高坎 & $\begin{array}{l}\text { Liangshan 1983c; Sichuansheng et al. 2006a; } \\
\quad \text { Xichang 1978d; data collection }\end{array}$ \\
\hline Xichang Xijiao Gongshe & 西昌西郊公社 & $\begin{array}{l}\text { Liangshan 1983c; Sichuansheng et al. 2006a; } \\
\quad \text { Xichang 1978d; data collection }\end{array}$ \\
\hline Xichang Xingsuo & 西昌星宿 & Sichuansheng et al. $2006 a$ \\
\hline Xichang Xinxingcun & 西昌新興村 & Zhongguo 2009 \\
\hline Xichang Xinying & 西昌新營 & Sichuansheng et al. 2006a; Zhongguo 2009 \\
\hline Xichang Xixicun & 西昌西溪村 & Sichuansheng et al. $2006 a$ \\
\hline Xichang Yangjiashan & 西昌楊傢山 & Liangshan 1987a; Liu 1981; Zhongguo 2009 \\
\hline Xichang Yanjiashan & 西昌羊山坡 & $\begin{array}{l}\text { Liangshan 1983a; Sichuansheng et al. 2006a; } \\
\quad \text { data collection }\end{array}$ \\
\hline Xichang Yezhugou & 西昌野豬溝 & Sichuansheng et al. $2006 a$ \\
\hline Xichang Yingpanshan & 西昌營盤山 & Chengdu et al. 2007a; data collection \\
\hline Xichang Yuanjiashan & 西昌袁家山 & $\begin{array}{l}\text { Liangshan 1983a; Sichuansheng et al. 2006a; } \\
\text { Zhongguo 2009; data collection }\end{array}$ \\
\hline Xichang Yunduanshan & 西昌云斷山 & Zhongguo 2009 \\
\hline Xichang Zengjiabao & 西昌曾傢堡 & Zhongguo 2009 \\
\hline Xichang Zhengjiafen & 西昌鄭傢墳 & Zhongguo 2009 \\
\hline Xichang Zhongguanpo & 西昌鈡官坡 & Liu 2009 \\
\hline Xichang Zhongjia Shanzui & 西昌鈡傢山嘴 & Zhongguo 2009 \\
\hline Xide Guluqiao & 喜德軲轤橋 & $\begin{array}{l}\text { Liangshan 1987b; Sichuansheng et al. 2006a; } \\
\text { Zhongguo } 2009\end{array}$ \\
\hline Xide Guoyuancun & 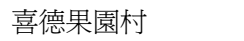 & Zhongguo 2009 \\
\hline Xide Lake Sihe & 喜德拉克公社四合 & $\begin{array}{l}\text { Liangshan 1977; Liangshan 1978; } \\
\text { Sichuansheng et al. 2006a; Zhongguo } \\
2009\end{array}$ \\
\hline Xide Lanfenba & 喜德爛墳垻 & Sichuansheng et al. 2006a; Zhongguo 2009 \\
\hline Xide Laoniuchang & 喜德老牛場 & Zhongguo 2009 \\
\hline Xide Qingli & 喜德清理 & Sichuansheng et al. 2006a; Zhongguo 2009 \\
\hline Xide Wadegu & 喜德瓦得姑 & Wang 1979; Zhongguo 2009 \\
\hline Xide Wamu & 喜德瓦木 & Wang 1979 \\
\hline Xide Wenjiaba & 喜德溫傢垻 & Zhongguo 2009 \\
\hline Xide Wuhe & 喜德伍合 & Sichuansheng et al. 2006a; Zhongguo 2009 \\
\hline Yanyuan Bei Ganhaixiang & 鹽源北干海乡 & Liangshan \& Chengdu 2009 \\
\hline Yanyuan Boshucun & 鹽源博樹村 & Zhongguo 2009 \\
\hline Yanyuan Caojiawan & 鹽源曹傢灣 & Li \& Liu 1992; Zhongguo 2009 \\
\hline Yanyuan Ganhai Sandadui & 鹽源干海三大隊 & Data collection \\
\hline Yanyuan Gesa & 鹽源格撒 & Huang 1983; Zhongguo 2009 \\
\hline Yanyuan Gong'anju & 鹽源公安局 & Liangshan \& Chengdu 2009; data collection \\
\hline Yanyuan Haimatang & 鹽源海馬塘 & Zhongguo 2009 \\
\hline Yanyuan Jiaodingshan & 鹽源轎頂山 & Sichuan \& Sichuan 1984; Zhongguo 2009 \\
\hline Yanyuan Jiejiafen & 鹽源解傢墳 & Zhongguo 2009 \\
\hline Yanyuan Laolongtou & 鹽源老龍頭 & $\begin{array}{l}\text { Jiang 2008; Lang 2006; Liangshan \& } \\
\text { Chengdu 2009; Liu 1998; Liu \& Li 1991; } \\
\text { Liu \& Tang 2006; Zhongguo 2009; data } \\
\text { collection }\end{array}$ \\
\hline Yanyuan Luowa & 鹽源洛瓦 & Liangshan \& Chengdu 2009 \\
\hline Yanyuan Maojiaba & 鹽源毛傢垻 & Liu 1991; Liu \& Tang 2001 \\
\hline
\end{tabular}

(Continued) 
Appendix A (Continued)

\begin{tabular}{|c|c|c|}
\hline SITE & & SOURCE \\
\hline Yanyuan Meiyu Bacun Sanzu & 鹽源梅雨八村三組 & Liu Hong pers. comm., 11/2011 \\
\hline Yanyuan Nanbianhe & 鹽源南边河 & Liangshan \& Chengdu 2009 \\
\hline Yanyuan Tangguan Liandi & 鹽源唐光連地 & Liangshan \& Chengdu 2009 \\
\hline Yanyuan Tangshidi & 鹽源唐氏地 & Zhongguo 2009 \\
\hline Yanyuan Wuming Baobao & 鹽源無名包包 & Zhongguo 2009 \\
\hline Yanyuan Wuqiu & 鹽源鳥丘 & Xichang $1978 a$ \\
\hline Yanyuan Wushidi & 鹽源伍氏地 & Liangshan \& Chengdu 2009; Zhongguo 2009 \\
\hline Yanyuan Xiaoguan Liangzi & 鹽源小官梁子 & Zhongguo 2009 \\
\hline Yanyuan Xiaohebian & 鹽源小河邊 & Liangshan \& Chengdu 2009; Zhongguo 2009 \\
\hline Yanyuan Xifan & 鹽源西藩 & Zhongguo 2009 \\
\hline Yanyuan Yingpanshan & 鹽源鹽源公安局 & Liangshan \& Chengdu 2009; Zhongguo 2009 \\
\hline Yanyuan Yingpanshan & 鹽源營盤山 & Zhongguo 2009 \\
\hline Yanyuan Zhushiba & 鹽源豬屎垻 & Liangshan \& Chengdu 2009 \\
\hline Yuexi Huayang & 越西華陽 & Zhongguo 2009 \\
\hline Yuexi Liaojiashan & 聊家山 & Mao \& Zou 1991; Zhongguo 2009 \\
\hline Yuexi Qu'ershan & 越西雀兒山 & Zhongguo 2009 \\
\hline Yuexi Wajimu & 越西瓦吉木 & Zhongguo 2009 \\
\hline Zhaojue Ada Bobu & 昭覺阿打波補 & Sichuansheng et al. $2006 a$ \\
\hline Zhaojue Bagu Erjue & 昭覺巴古爾覺 & Liangshan et al. 2009 \\
\hline Zhaojue Bakeku Cun & 昭覺巴克苦村 & Liangshan et al. 2009 \\
\hline Zhaojue Chike Boxixiang & 昭覺齒可波西鄉 & Liangshan et al. 2009 \\
\hline Zhaojue Daba Gongshe & 昭覺大垻公社 & Liangshan 1977 \\
\hline Zhaojue Dabaozi Geze & 昭覺大堡子格則 & Zhao Deyun pers. comm., 4/2011 \\
\hline Zhaojue Da'edou Gezi & 昭覺大俄都格則 & Zhao Deyun pers. comm., 4/2011 \\
\hline Zhaojue Dawenquan & 昭覺大溫泉 & Liangshan 1977 \\
\hline Zhaojue Dipo Cier & 昭覺氏坡此爾 & Zhongguo 2009 \\
\hline Zhaojue Eba Buji & 昭覺俄巴佈吉 & Liangshan et al. 2009 \\
\hline Zhaojue Erba Keku & 昭覺尔巴克苦 & $\begin{array}{l}\text { Liangshan et al. 2010, 2011; Liangshan Yizu } \\
\text { Zizhizhou Bowuguan 1977, } 1981\end{array}$ \\
\hline Zhaojue Ergu Zege & 昭覺尔姑 & Zhao Deyun pers. comm., 4/2011 \\
\hline Zhaojue Erwu & 昭覺二五 & Zhongguo 2009 \\
\hline Zhaojue Fuchengqu & 昭覺附城區 & $\begin{array}{l}\text { Liangshan et al. 2010, 2011; Liangshan Yizu } \\
\text { Zizhizhou Bowuguan 1977, } 1981\end{array}$ \\
\hline Zhaojue Geze Yangpeng & 昭覺格則羊棚 & Zhao Deyun pers. comm., 4/2011 \\
\hline Zhaojue Haba Qiehe & 昭覺哈巴切合 & Zhao Deyun pers. comm., 4/2011 \\
\hline Zhaojue Hangan Yide & 昭覺汗干依德 & Zhao Deyun pers. comm., 4/2011 \\
\hline Zhaojue Hebo & 昭覺合波 & Liu Hong pers. comm., 11/2010 \\
\hline Zhaojue Heiluo & 昭覺黑洛 & Zhao Deyun pers. comm., 4/2011 \\
\hline Zhaojue Jike Jiejue/Layimu & 昭覺吉克傑覺 & Liangshan et al. 2009 \\
\hline Zhaojue Jinzi Niaobu & 昭覺金子鳥佈 & Liangshan et al. 2009 \\
\hline Zhaojue Keri Watuo & 昭覺軍屯 & Zhongguo 2009 \\
\hline Zhaojue Kujia Ebu & 昭覺克日瓦托 & Zhao Deyun pers. comm., 4/2011 \\
\hline Zhaojue Machu Nawo & 昭覺庫家俄佈 & Zhongguo 2009 \\
\hline Zhaojue Mucuo Naijie & 昭覺馬処鈉窩 & Liangshan et al. 2009 \\
\hline Zhaojue Muergguo & 昭覺木措乃姐 & Zhongguo 2009 \\
\hline Zhaojue Mujueke & 昭覺木爾果 & Zhongguo 2009 \\
\hline Zhaojue Naituo & 昭覺莫覺柯 & Zhongguo 2009 \\
\hline Zhaojue Niaopo & 昭覺乃托 & Liangshan et al. 2009 \\
\hline Zhaojue Pusu Bohuang & 昭覺鸟坡 & Liangshan et al. 2009 \\
\hline Zhaojue Qianjinshe & 昭覺幞蘓波湟 & Zhongguo 2009 \\
\hline Zhaojue Sikaixiang & 昭覺前進社 & Zhongguo 2009 \\
\hline
\end{tabular}


Appendix A (Continued)

\begin{tabular}{|c|c|c|}
\hline SITE & & SOURCE \\
\hline Zhaojue Siyi Ergu & 昭覺四開躴 & Zhongguo 2009 \\
\hline Zhaojue Teluocun & 昭覺司益爾古 & Liangshan et al. 2009 \\
\hline Zhaojue Tiaowoba & 昭覺特洛村 & Zhongguo 2009 \\
\hline Zhaojue Waluo Geci & 昭覺跳窩垻 & Zhongguo 2009 \\
\hline Zhaojue Watuo & 昭覺瓦洛格側 & Zhongguo 2009 \\
\hline Zhaojue Wazhaishan & 昭覺瓦托 & $\begin{array}{l}\text { Liangshan et al. 2010, 2011; Liangshan Yizu } \\
\text { Zizhizhou Bowuguan 1977, } 1981\end{array}$ \\
\hline Zhaojue Yibijia & 昭覺瓦寨山 & Zhao Deyun pers. comm., 4/2011 \\
\hline Zhaojue Yihe Geci & 昭覺依合格側 & Zhongguo 2009 \\
\hline \multicolumn{3}{|c|}{ Panzhihua City, Sichuan Province } \\
\hline Luquan Yingpanbao & 祿勸營盤寶 & Kunmingshi et al. 2007 \\
\hline Miyi Hejiaba & 米易何傢垻 & Zhongguo 2009 \\
\hline Miyi Lianhua Gongshe & 米易蓮花公社 & Data collection \\
\hline Miyi Sanjingxiang & 米易三井巷 & Sichuansheng et al. $2006 a$ \\
\hline Miyi Tianba & 米易田垻 & Sichuansheng et al. $2006 a$ \\
\hline Miyi Wanqiu & 米易彎丘 & $\begin{array}{l}\text { Liangshan Yizu Zizhizhou Bowuguan 1981; } \\
\text { Liu \& Zou 1995; Sichuansheng et al. } \\
\text { 2006a }\end{array}$ \\
\hline Miyi Yuanjiabao & 米易袁傢顁 & Zhongguo 2009 \\
\hline Miyi Zhaizishan & 米易寨子山 & Liu 2009 \\
\hline Renhe Baihushan & 米易白虎山 & Sichuansheng et al. $2006 a$ \\
\hline Renhe Gonghe & 仁和共和 & Zhongguo 2009 \\
\hline Renhe Huilongwa & 仁和包龍灣 & Zhongguo 2009 \\
\hline Renhe Xiawan & 仁和下灣 & Zhongguo 2009 \\
\hline Renhe Xicaoping & 仁和席草坪 & Zhongguo 2009 \\
\hline Renhe Yangjiashan & 仁和楊傢山 & Zhongguo 2009 \\
\hline Xiqu Yanwan & 西區岩灣 & Zhongguo 2009 \\
\hline Yanbian Huimin & 鹽源惠民 & Zhongguo 2009 \\
\hline Yanbian Pulongcun & 鹽源普隆村 & Zhongguo 2009 \\
\hline Yanbian Xicaodi & 鹽源席草地 & Zhongguo 2009 \\
\hline Yanbian Xinlin & 鹽源新林 & Zhongguo 2009 \\
\hline Yanbian Yongxing & 鹽源永興 & Zhongguo 2009 \\
\hline Yanbian Yumen Wanxiao & 鹽源漁門完小 & Dukoushi 1986; Zhongguo 2009 \\
\hline \multicolumn{3}{|l|}{ Yunnan Province } \\
\hline Ninglang Cunyi & 寧蒗翠依 & Zhongguo \& Yunnansheng 2001 \\
\hline Ninglang Daxingzhen & 寧蒗大興鎭 & $\begin{array}{l}\text { Yunnansheng 1983b; Zhongguo \& } \\
\text { Yunnansheng } 2001\end{array}$ \\
\hline Ninglang Jinyangcun & 寧蒗金鍚村 & Zhongguo \& Yunnansheng 2001 \\
\hline Ninglang Kaijicun & 寧蒗開基村 & Zhongguo \& Yunnansheng 2001 \\
\hline Ninglang Pijiangcun & 寧蒗皮匠村 & Zhongguo \& Yunnansheng 2001 \\
\hline Yongsheng Duizi & 永勝堆子 & Yunnansheng et al. 2010; data collection \\
\hline Yongsheng Haiyancun & 永勝海沿村 & Zhongguo \& Yunnansheng 2001 \\
\hline Yongsheng Laoying & 永勝老營等 & Zhongguo \& Yunnansheng 2001 \\
\hline Yongsheng Longtan & 永勝龍澤銅器 & Zhongguo \& Yunnansheng 2001 \\
\hline Yongsheng Lujiajie & 永勝陸傢界 & Zhongguo \& Yunnansheng 2001 \\
\hline Yongsheng Qiaodiping & 永勝蕎地坪 & Zhongguo \& Yunnansheng 2001 \\
\hline Yongsheng Sankuaishi & 永勝三塊石 & Zhongguo \& Yunnansheng 2001 \\
\hline Yongsheng Taoyingcun & 永勝陶營村 & Zhongguo \& Yunnansheng 2001 \\
\hline Yongsheng Yanjiaqing & 永勝嚴傢箐銅鼓 & Zhongguo \& Yunnansheng 2001 \\
\hline
\end{tabular}

* "Data collection" indicates sites for which I had access to original material. 


\section{NOTES}

1. The region is just a little smaller than South Carolina $\left(82,931 \mathrm{~km}^{2}\right)$ or Austria $\left(83,855 \mathrm{~km}^{2}\right)$.

2. Chinese characters for all site names can be found in Appendix A, so are not repeated in the text.

3. These and following dates were calibrated using OxCal online radiocarbon calibration using IntCal13 with an error range of $2 \sigma$. For a discussion on calibration, consult Reimer et al. 2013. https://c14.arch.ox.ac.uk/oxcal.html\#program.

4. The site is on the easternmost fringe of Yanyuan and geographically belongs to the southwest.

5. In the study cited here, I present a detailed comparison of objects from the art market with those excavated in Yanyuan, pointing out that a number of objects from Yanyuan graves showed outside influence or were even imports, while others are clearly local products. The objects retrieved from the local art or antiquities market show striking similarities to objects retrieved from graves in Yanyuan, but as some objects from both "contexts" were of foreign origin to begin with, it is difficult to tell if the grave robbers selling these items to the art dealers had retrieved them from graves in Yanyuan or in Yunnan, for instance.

6. As the material is unpublished, all descriptions of Yongsheng Duizi are based on personal handling of the excavated material during a short stay in Yunnan and an informal presentation titled "Yongsheng Duizi yizhi fajue” 永勝對子遺址發掘 [Excavation of Yongsheng Duizi site] given at an informal gathering in Kunming in December 2010 by archaeologists from Yunnansheng Wenwu Kaogu Yanjiusuo 雲南省文物考古硏究所, Lijiangshi Bowuguan 麗江市博物館, and Lijiangshi Yongshengxian Wenwu Guanlisuo 麗江市永勝縣文物管理所. The author was not granted permission to use any images from the presentation for publication, so here descriptions must suffice.

7. Originally, Guantianshan and Yingpanshan were thought to be two separate sites, but now it is clear that it is one large site, hence the double name.

\section{REFERENCES CITED}

Aba ZangZu Qiangzu Zizhizhou Wenwu Guanlisuo 阿垻藏族姜族自治州文物管理所 AND ChENGDU WENWU KaOGU YANJIUSUO 成都文物考古咑究所

2009 Zhongguo Xinan diqu shiguanzang wenhua diaocha yu fajue (1938-2008) 國新南地區石棺葬文化 調查與發掘 (1938-2008) [Survey and excavation of stone-cist grave culture sites in Southwest China (1938-2008)]. Chengdu: Sichuan Daxue Chubanshe.

Aba Zangzu Zizhizhou Wenwu Guanlisuo 阿垻藏族自治州文物管理所, Chengdu Wenwu KaOgu YANJIUSUO 成都文物考古硏究所, AND MA'ERKANG XIAN WENHUA TIYUju 馬爾康縣文化體育侷

2005 Sichuan Ma’erkangxian Mu’erxi yizhi shijue jianbao 四川馬爾康險木爾溪遺址實掘簡報 [Preliminary report on test excavations at Mu'erxi site, Ma'erkang County, Sichuan]. Chengdu kaogu faxian 成都考古發現2005 [Chengdu archaeological discoveries 2005]: 25-40.

Aba Zangzu Zizhizhou Wenwu GuANLisuo 阿垻藏族自治州文物管理所 AND LiXian WenwUgUAN 理縣文物舘

1987 Sichuan Lixian Jiashan shiguanzang fajue qingli baogao 四川理縣佳山石棺葬發掘清理報告 [Excavation report of the stone-cist graves of Lixian Jiashan in Sichuan]. Nanfang minzu kaogu 南方民族考古 [Southern ethnology and archaeology] 1:211-237.

BAOXINGXIAN WenHUAGUAN 寶興縣文化館

1982 Sichuan Baoxingxian Handai shiguanmu 四川寶興賢漢代石棺墓 [The Han stone-cist graves in Baoxing County, Sichuan]. Kaogu 考古 [Archaeology] 4:377-380.

Chengdu, Liangshanzhou, and Huilixian [Chengdu Wenwu Kaogu Yanjiusuo 成都文物考古 研究所, LiangShanzhou Bowuguan 涼山州博物館, AND Huilixian Wenwu Guanlisuo 會理縣文物 管理所]

20082006 niandu Sichuan Huilixian Dongzui yizhi fajue jianbao 2006年度四川會理縣東咀遺址 發掘簡報 [Preliminary report of the 2006 excavations of Dongzui site in Huili County, Sichuan]. Chengdu kaogu faxian 成都考古發現2006 [Chengdu archaeological discoveries 2006]: 93-112.

2009 Sichuan Huilixian Leijiashan mudi M1 fajue baogao 四川會理縣雷傢山墓地M1發掘報告 [Excavation report of grave M1 at Leijiashan cemetery, Huili County, Sichuan]. Chengdu kaogu faxian 成都考古發現2007 [Chengdu archaeological discoveries 2007]: 229-259.

Chengdu, Liangshanzhou, and Xichangshi [Chengdu Wenwu Kaogu Yanjiusuo 成都文物考古 研究所, LiangShanZHOU Bowuguan 涼山州博物館, AND Xichangshi Wenwu Guanlisuo 西昌市文物 管理所]

2008 Sichuan Xichangshi Qimugou yizhi 2006 niandu shijue jianbao 四川西昌市棲木溝遺址2006 年度試掘簡報 [Preliminary report of the 2006 test excavations at Qimugou site in Xichang 
City, Sichuan]. Chengdu kaogu faxian 成都考古發現2006 [Chengdu archaeological discoveries 2006]: 67-92.

2009 Sichuan Xichangshi Qimugou yizhi 2006 niandu fajue jianbao 四川西昌市棲木溝遺址2006 年度試掘簡報 [Preliminary report of the 2006 excavation of Qimugou site in Xichang City, Sichuan]. Sichuan wenwu 四川文物 [Sichuan cultural relics] 3:3-14.

Chengdu Ditu Chubanshe 成都地圖出版社

2010 Sichuansheng dituji 四川省地圖集 [Atlas of Sichuan Province]. Chengdu: Chengdu Ditu Chubanshe.

Chengdu Wenwu Kaogu Yanjiusuo 成都文物考古研究所, Liangshan Yizu Zizhizhou Bowuguan 涼山彝族自治州博物館, AND XICHANGSHI WENWU GUANLISUO 西昌市文物管理所

2006 Sichuan Xichangshi Daxing Henglanshan yizhi diaocha shijue jianbao 四川西昌市大興橫闌山 遺址調查試掘簡報 [Preliminary excavation report of Daxing Henglanshan site in Xichang City, Sichuan]. Chengdu kaogu faxian 成都考古發現2004 [Chengdu archaeological discoveries 2004]: 20-87.

2007a Sichuan Xichangshi Yingpanshan yizhi fajue jianbao 四川西昌市營盤山遺址發掘簡報 [Preliminary excavation report of Yingpanshan site in Xichang City, Sichuan]. Chengdu kaogu faxian 成都考古發現2005 [Chengdu archaeological discoveries 2005]: 62-87.

$2007 b$ Sichuan Xichangshi Jingjiuxiang Ma'anshan yizhi diaocha shijue jianbao 四川西昌市經久縣 馬鞍山遺址調查試掘見報 [Preliminary excavation report of Jingjiuxiang Ma'anshan site in Xichang City, Sichuan]. Chengdu kaogu faxian 成都考古發現2005 [Chengdu archaeological discoveries 2005]: 88-113.

Chengdushi Wenwu Kaogu Yanjiusuo 成都市文物考古㸴究所, Liangshan Yizu Zizhizhou BowuGUAN 涼山彝族自治州博物館, AND MIANNINGXIAN WENWU GUANLISUO 冕寧縣文物管理所

20122010 nian Sichuansheng Mianningxian Zhaojiawan yizhi diaocha jianbao 2010年四川省冕寧 縣趙傢灣遺址調查簡報 [Preliminary report of the 2010 survey at Zhaojiawan site in Mianning County, Sichuan Province]. Chengdu kaogu faxian 成都考古發現2009 [Chengdu archaeological discoveries 2009]: 45-65.

Chengdushi Wenwu Kaogu Yanjiusuo 成都市文物考古硏究所, LiangShanZhou Bowuguan 涼山州 博物館, AND DechangXian Wenguansuo 德昌縣文管所

2009 Sichuan Liangshanzhou Dechangxian Wangjiaping yizhi diaocha jianbao 四川涼山州德昌縣 汪傢坪遺址調查簡報 [Preliminary survey report of Wangjiaping site, Dechang County, Liangshan Prefecture, Sichuan]. Chengdu kaogu faxian 成都考古發現2007 [Chengdu archaeological discoveries 2007]: 213-228.

Chuxiong Yizu Zizhizhou Wenwu Guanlisuo 楚雄彝族自治州文物管理所 AND YunNansheng BowUGUAN GONGZUODUi 云南省博物馆工作队

1986 Yunnan Yongren Yongdingzhen shibanmu qingli jianbao 雲南永仁維的石棺墓地發掘記略 [Preliminary investigation report of the Yongren Yongdingzhen stone-cist graves, Yunnan]. Wenwu 文物 [Cultural relics] (7) : 31-34.

D'Alpoim Guedes, Jade

2013 Adaptation and Invention during the Spread of Agriculture to Southwest China. Ph.D. diss. Department of Anthropology, Harvard University, Cambridge, MA.

2015 Rethinking the spread of agriculture to the Tibetan Plateau. Holocene 25(9) :1498.

D'Alpoim Guedes, Jade, and Ethan E. Butler

2014 Modeling constraints on the spread of agriculture to southwest China with thermal niche models. JQI Quaternary International 349:29-41.

Debaine-Francfort, Catherine

1995 Du Néolithique à l'Age du Bronze en Chine du Nord-Ouest: la culture de Qijia et ses connexions. Paris: Editions Recherche sur les civilisations.

DukOUSHI WENwU GUANLICHU 渡口市文物管理處

1986 Sichuan Yanbianxian shiguanzang fajue jianbao 四川鹽邊縣石棺葬發掘簡報 [Preliminary excavation report of the Yanbian County stone-cist graves, Sichuan]. Kaogu yu wenwu 考古與 文物 [Archaeology and cultural relics] 2:21-22.

FALKenHAUSEN, LOTHAR VON

1988 Ritual Music in Bronze Age China: An Archaeological Perspective. Ph.D. diss. Department of Anthropology, Harvard University, Cambridge, MA.

FAN YONG 範勇

2007 Yunnan qingtong wenhua de quxi leixing yanjiu 雲南青銅文化的區係類型硎究 [Research on the typology of the bronze-age cultures of Yunnan]. Sichuan wenwu 四川文物 [Sichuan cultural relics] $2: 64-73$. 
Flad, Rowan K., and Pochan Chen

2013 Ancient Central China: Centers and Peripheries along the Yangzi River. Cambridge: Cambridge University Press.

Guizhousheng Bowuguan KAOguzu 貴州省博物館考古組 AND WeiningXian WenhuAJU 威寧縣 文化局

1981 Weining Zhongshui Hanmu 威寧中水漢墓 [The Han graves of Weining Zhongshui]. Kaogu xuebao 考古學報 [Acta Archaeologica Sinica] 2:217-244.

Guizhousheng Wenwu Kaogu Yanjiusuo 貴州省文物考古砰究所, Sichuan Daxue Lishi Wenhua XUEHUAN KAOguXi 四川大學歷史文化學院考古係, AND WeININGXIAN WenWU BAOHU GUANLISUO 威寧縣文物保護管理所

2006 Guizhou Weiningxian Jigongshan yizhi 2004 nian fajue jianbao 貴州威寧縣雞公山遺址2004年 發掘簡報 [Preliminary report of the 2004 excavation of Jigongshan site, Weining County, Guizhou]. Kaogu 考古 [Archaeology] 8:11-27.

He KunYu 何錕宇

2009 Minjiang shangyou shiguanzang de fenqi yu niandai 岷江上游石棺葬的分期與年代 [Typology and chronology of the stone-cist graves of the upper Min River]. Sichuan wenwu 四川文物 [Sichuan cultural relics] $4: 43-51$.

HeIn, ANKe

2013 Cultural Geography and Interregional Contacts in Prehistoric Liangshan (Southwest China). Ph.D. diss. Interdepartmental Program of Archaeology, University of California, Los Angeles (UCLA).

$2014 a$ Interregional contacts and geographic preconditions in the prehistoric Liangshan region, Southwest China. Quaternary International 348:194-213.

$2014 b$ Metal, salt, and horse skulls: Elite-level exchange and long-distance human movement in prehistoric Southwest China, in Reconsidering the Crescent-Shaped Exchange Belt: Methodological, Theoretical and Material Concerns of Long-Distance Interactions in East Asia Thirty Years after Tong Enzheng: 89-108, ed. Anke Hein. Oxford: Archaeopress.

2014c Reconsidering the Crescent-Shaped Exchange Belt: Methodological, Theoretical and Material Concerns of Long-Distance Interactions in East Asia Thirty Years after Tong Enzheng, ed. Anke Hein. Oxford: Archaeopress.

2015 Environmental preconditions and human response: Subsistence practices at prehistoric settlement sites in the Liangshan area, Southwest China. Asian Archaeology 3:39-94.

2017 The Burial Record of Prehistoric Liangshan in Southwest China: Graves as Composite Objects. Cham, Switzerland: Springer.

HuAng Chenzong 黃承宗

1983 Luguhu pan chutu wenwu diaochaji 瀘沽湖畔出土文物調查紀 [Survey record of cultural relics from Lake Lugu]. Kaogu 考古 [Archaeology] 10:952-954.

HUANG JIAXIANG 黃家祥

2000 Xichang Lizhou xinshiqishidai yizhi zhi jianlun 西昌禮州新石器時代遺址之檢論 [Preliminary discussion of the Xichang Lizhou Neolithic site]. Sichuan wenwu 四川文物 [Sichuan cultural relics] $4: 3-9$.

Huilixian Wenguansuo 會理縣文管所, LiangShan Yizu Zizhizhou Bowuguan 涼山彞族自治州 博物館, AND Sichuansheng Wenwu KaOgu Yanjiusuo 四川省文物考古研究所

2004 Sichuan Huilixian Fenjiwan muqun fajue jianbao 四川會理縣䔬箕灣墓群發覺簡報 [Preliminary excavation report of Fenjiwan cemetery, Huili County, Sichuan]. Kaogu 考古 [Archaeology] $10: 36-46$.

HuILIXIAN WENHUAGUAN 會理縣文化館

1977 Sichuan Huili chutu de yimian tonggu 四川會理出土的一面銅鼓 [A bronze drum excavated in Huili, Sichuan]. Kaogu 考古 [Archaeology] 3:215-216.

JIANG XIANJIE 姜先傑

1994 Xichang Dongping yizhi zhitong zhubi yuanyin chutan 西昌東坪遺址治銅鑄幣原因初探 [Preliminary discussion of the reason behind the bronze-coin finds at Dongping site, Xichang]. Sichuan wenwu 四川文物 [Sichuan cultural relics] 9:46-50.

JIANG ZHANGHUA 江章華

2007 Anninghe liuyu kaoguxue wenhua shixi 安寧河流域考古學文化試析 [Trial sequencing of the Anning River archaeological cultures]. Sichuan wenwu 四川文物 [Sichuan cultural relics] 5:3-11. 
2008 Dui Yanyuan pendi qingtong wenhua de jidian renshi 對鹽源盆地青銅文化的幾點認識 [A few insight into the bronze-age cultures of the Yanyuan Basin], in Nanfang Sichouzhilu yanjiu lunji 南方絲綢之路研究論集 [Collection of essays on the Southern Silk Road]: 343-355, ed. Duan Yu 段渝. Chengdu: Sichuan Bashu Chubanshe 四川出版集團巴蜀書社.

Kunmingshi Bowuguan 昆明市博物館, LIAngshanzhou Bowuguan 涼山州博物館, LuQUanXIAN Wenwu GuANLISUO 祿勸縣文物管理所, AND HuILIXIAN Wenwu GuANLISUO 會理縣文物管理所

2007 Jinshajiang zhongyou diqu liangchu xinshiqishidai shiguanzang de fajue 金沙江中游地區兩処 新石器時代石棺葬的發掘 [Excavation of the Neolithic stone-cist graves of two sites along the middle courses of the Jinsha River]. Kaogu 考古 [Archaeology] 11:17-25.

LANG JIANFENG 郎劍鋒

2006 Laolongtou yicun de chubu yanjiu 老龍頭遺存的初步研究 [Preliminary research on the Laolongtou remains]. Master's thesis. Kaogu Wenbo Xueyuan 考古文博學院, Peking University 北京大學, Beijing.

Li Chaozhen 李朝真

1983 Yunnan Xiangyun Jiancun shiguomu 雲南祥雲檢村石槨墓 [The Xiangyun Jiancun stoneconstruction graves, Yunnan]. Wenwu 文物 [Cultural relics] 5:33-41, 99.

Li KUNSHENG 李昆聲

1998 Yunnan kaoguxue lunji 雲南考古學論集 [Collected essays on the archaeology of Yunnan]. Kunming: Yunnan Renmin Chubanshe 雲南人民出版社.

Li RONGYOU 李榮友 AND LIU HoNG 劉弘

1992 Yanyuan faxian Handai shishimu 鹽源發現漢代石室墓 [Han-time stone-construction graves discovered in Yanyuan]. Sichuan wenwu 四川文物 [Sichuan cultural relics] 4:71.

LIANGSHAN DIQU KaOgUdui 涼山地區考古隊

1978 Sichuan Liangshan Xide Lake Gongshe dashimu 四川涼山喜德拉克公社大石墓 [The megalithic graves of Sichuan Liangshan Xide Lage Gongshe]. Kaogu 考古 [Archaeology] 2: 97-103.

LIANGSHAN YizU DiQU KAOGUDUI 涼山彝族地區考古隊

1981 Sichuan Liangshan Zhaojue shibanmu fajue jianbao 四川涼山昭覺石板墓發掘簡報 [Preliminary excavation report of the stone-construction graves of Liangshan Zhaojue, Sichuan]. Kaoguxue jikan 考古學集刊 [Journal of archaeology] 1:127-132.

LiangShan Yizu Zizhizhou Bowuguan 涼山彞族自治州博物館

1977 Liangshanzhou Zhaojuexian shibanmu fajue jianbao chugao 涼山州昭覺顯石板墓發掘簡報 初稿 [Preliminary excavation report of the stone-construction graves of Zhaojue Coungy, Liangshan Prefecture]. Liangshan Yizu nulizhi yanjiu 涼山彞族奴隸制硏究 [Research on the Liangshan Yi Slave-Society] $1: 88-92$.

1981 Miyi Wanqiu de liangzuo dashimu 米易彎丘的兩座大石墓 [The two megalithic graves of Miyi Wanqiu]. Kaoguxue jikan 考古學集刊 [Journal of archaeology] 1:120-126.

1983a Sichuan Pugexian Wadaluo yizhi diaocha 四川普格縣瓦打洛遺址調查 [Survey of the Wadaluo site, Puge County, Sichuan]. Kaogu 考古 [Archaeology] 6:562-564.

1983 Sichuan Xichangshi jiaoda shimu 四川西昌市郊大石墓 [The large stone graves of Xichang City, Sichuan]. Kaogu 考古 [Archaeology] 6:565-566.

1983c Sichuan Xichang yihaomu fajue jianbao 四川西昌一號墓發掘簡 [Preliminary excavation report of Sichuan Xichang grave 1]. Kaoguxue jikan 考古學集刊 [Journal of archaeology] 3:143-149.

1984 Sichuan Xichang Tianwangshan shihaomu qingli jianbao 四川西昌天王山十號墓清理簡報 [Preliminary excavation report of Sichuan Xichang Tianwangshan grave 10]. Kaogu 考古 [Archaeology] 12:1092-1095.

$1987 a$ Sichuan Xichang Yangjiashan huozang muqun 四川西昌楊傢山火葬墓群 [Sichuan Xichang Yangjiashan cremation cemetery]. Wenwu ziliao congkan 文物資料叢刊 [Cultural relics journal] $10: 151-154$

1987b Sichuan Xidexian qingli yizuo dashimu 四川喜德縣清理一座大石墓 [Investiagion into a megalithic grave in Xide County, Sichuan]. Kaogu 考古 [Archaeology] 3:197-264.

1990 Sichuan Xichang Beishan, Xiaohuashan, Huangshuitang dashimu 四川西昌北山、小花山、 黃水塘大石墓 [The megalithic graves of Sichuan Xichang Beishan, Xiaohuashan, and Huangshuitang]. Wenwu 文物 [Cultural relics] 5:64-67.

Liangshan Yizu Zizhizhou Bowuguan 涼山彞族自治州博物館 and Chengdu Wenwu Kaogu YanJIUSUO 成都文物考古㗑究所

2009 Laolongtou mudi yu Yanyuan qingtongqi 老龍頭墓地與鹽源青銅器 [Laolongtou cemetery and the Yanyuan bronzes]. Beijing: Wenwu Chubanshe 文物出版社. 
Liangshan Yizu Zizhizhou Bowuguan 涼山彞族自治州博物館, Chengdu Wenwu Kaogu Yanjiusuo 成都交物考古研究所, AND XICHANGSHI WENWU GUANLISUO 西昌市文物管理所

2006 Sichuan Xichangshi Mimilang yizhi diaocha shijue jianbao 四川西昌市咪咪啷遺址調查試掘 簡報 [Preliminary report on the survey and trial excavation at Mimilang site, Xichang City, Sichuan]. Chengdu kaogu faxian 成都考古發現2004 [Chengdu archaeological discoveries 2004]: 39-52.

LiangShan Yizu Zizhizhou Bowuguan 涼山彞族自治州博物館 AND MianningXian WenwU GuANLISUO 冕寧縣文物管理所

2006 Sichuan Liangshan Mianning Sanfentun yizhi shijue jianbao 四川涼山冕寧三分屯遺址試掘 簡報 [Preliminary excavation report of Liangshan Mianning Sanfentun, Sichuan]. Sichuan wenwu 四川文物 [Sichuan cultural relics] 1:31-35.

LiangShan Yizu Zizhizhou Bowuguan 涼山彞族自治州博物館 AND Pugexian Wenhuaguan 普格縣 文化館

1987 Sichuan Puge Xiaoxingchang dashimuqun de diaocha yu qingli 四川普格小興場大石墓群的 調查與清理 [Survey and investigation of the Puge Xiaoxingchang megalithic graves, Sichuan]. Wenwu ziliao congkan 文物資料叢刊 [Cultural relics journal] 10:155-158.

Liangshan Yizu Zizhizhou Bowuguan 涼山彞族自治州博物館, Pugexian Wenhuaguan 普格縣 文化館, And Pugexian Kexue Jishu Qingbao WeiYuanhui 普格縣科學技術情報委員會

1982 Sichuan Pugexian Xiaoxingchang dashimu 四川普格縣小興場大石墓 [The megalithic graves of Xiaoxingchang, Puge County, Sichuan]. Kaogu yu wenwu 考古與交物 [Archaeology and cultural relics] $5: 34-38$.

Liangshan Yizu Zizhizhou Bowuguan 涼山彞族自治州博物館, Sichuan Daxue Kaoguxue XI 四川 大學考古學係, AND ZHAOJUEXIAN WENWU GUANLISUO 昭覺縣文物管理所

2010 Sichuan Zhaojuexian gu wenhua yicun de diaocha he qingli 四川省昭覺縣古文化遺存的調查 和清理 [Survey and investigation into the ancient sites of Zhaojue County, Sichuan]. Nanfang Minzu Kaogu 南方民族考古 [Southern ethnology and archaeology] 6:375-408.

2009 Sichuan Zhaojuexian Haogucun gumuqun de diaocha he qingli 四川昭覺縣好谷村古墓群的 調查和清理 [Survey and investigation into the ancient cemetery of Haogucun, Zhaojue County, Sichuan]. Kaogu 考古 [Archaeology] 4:30-40.

2011 Sichuan Zhaojuexian Chengbeixiang Guducun de Handai yizhi he muzang 四川昭覺縣城北 鄉谷都村的漢代遺址和墓葬 [The Han settlement and graves of Chengbeixiang Guducun, Zhaojue County, Sichuan]. Nanfang Minzu Kaogu 南方民族考古 [Southern ethnology and archaeology] $7: 481-494$.

LIU HoNG 劉弘

2009 Cong shan junling zhong de “lüzhou”-Anning hegu wenhua yicun diaocha yanjiu 从山峻岭中的 “绿洲”一安宁河谷文化遗存调查㸴究 [From an oasis in between the mountains-A survey of the ancient sites of the Anning River Valley]. Chengdu: Bashu Chubanshe 巴蜀书社.

LiU HoNg 劉弘 AND TANg LIANG 唐亮

2001 Yanyuan faxian gudai minzu muzang he jisikeng 鹽源發現古代民族墓葬和祭祀坑 [The graves and offering pits of ancient people discovered in Yanyuan]. Zhongguo wenwubao 中國文物報 [Chinese cultural relics journal] (September 14): 3 .

2006 Laolongtou muzang he Yanyuan qingtongqi [The Laolongtou graves and the Yanyuan bronzes]. Zhongguo lishi wenwu [Journal of National Museum of China] 6:22-29.

LiU Hong 劉弘 AND WANG Wu 王吳

2007 Henglanshan yizhi he Lizhou yizhi jingji xingtai zhi bijiao 橫欄山遺址和禮州遺址經濟形態之 比較 [Comparison of subsistence systems of Henglanshan and Lizhou sites]. Sichuan wenwu 四川交物 [Sichuan cultural relics] 5:43-49.

Liv SHIXU 劉世旭

1981 Xichang Yangjiashan xinshiqishidai wanqi yicun 西昌楊家山新石器時代晚期遺存 [The Late Neolithic remains of Xichang Yangjiashan]. Wenwu ziliao congkan 文物資料叢刊 [Cultural relics journal] $5: 201-203$.

1991 Sichuan Yanyuanxian Maojiaba gumuzang chutu zaoqi tonggu de chubu yanjiu 四川鹽源縣 毛傢垻古墓葬出土早期銅鼓的初步硑究 [Preliminary research on the early bronze drums retrieved from the ancient graves of Maojiaba, Yanyuan County, Sichuan]. Zhongguo wenwu shijie 中國文物世界 [The world of Chinese antiquities] 70:113-127.

1998 Sichuan Yanyuanxian chutu de renshouwen qingtong jisi zhipian kaoshi 四川鹽源縣出土的 人獸紋青銅祭祀枝片考釋 [A few thoughts on the bronze ritual objects depicting men and beasts excavated in Yanyuan County, Sichuan]. Sichuan wenwu 四川文物 [Sichuan cultural relics] $5: 11-17$. 
LiU SHIXU 劉世旭 AND Li Rongyou 李榮友

1991 Yanyuan Hanmu chutu zhanguo tonggu 鹽源漢墓出土戰國銅鼓 [The Warring-States bronze drums excavated from Han graves in Yanyuan]. Zhongguo wenwubao 中國文物報 [Chinese cultural relics journal] (May 12): 2.

LiU SHIXU 劉世旭 AND Zou LiN 邹林

1995 Miyi Wanqiu liangzuo dashimu 米易彎丘兩座大石墓 [Two megalithic graves at Miyi Wanqiu], in Dukou wenwu kaogu, lishi, minzu yanjiu ziliao xuanji 渡口文物考古、歷史、民族硏究 資料選集 [Selected research material on the archaeology, history, and ethnic groups of Dukou]: 98-101, ed. Dukoushi Wenwu Guanlichu 渡口市文物管理處. Beijing: Kexue Chubanshe 科學出版社.

LiU Xu 劉旭 AND Sun Hua 孫華

2009 Yeshishan yicun de chubu fenxi 野石山遺存的初步分析 [Preliminary analysis of the Yeshishan remains]. Kaogu 考古 [Archaeology] 8:67-78.

Lizhou Yizhi Lianhe KaOgu Fajuedui 禮州遺址聯合考古發掘隊

1980 Sichuan Xichang Lizhou faxian de Hanmu 四川西昌禮州發現的漢墓 [The Han graves discovered at Xichang Lizhou, Sichuan]. Kaogu 考古 [Archaeology] 5:406-416.

LUO ERHU 儸二虎

2012 Wenhua yu shengtai, shehui, zuqun: Chuandian Qingzang minzu zoulang shiguanzang yanjiu 文化與生態、社會、族群 : 川槇青藏民族走廊石棺葬砰究 [Culture and subsistence, society, groups: Research on the stone-cist graves of the ethnic exchange corridor across Yunnan, Sichuan, Qinghai, and Tibet]. Beijing: Kexue Chubanshe 科學出版社.

MAO RUIFEN 毛瑞芬 AND Zou Lin 㮲麟

1991 Sichuan Yuexixian Liaojiashan faxian Zhanguo Xihan tongtieqi 四川越西縣聊家山發現戰國 西漢銅鐵器 [Warring States and Western Han bronze and iron objects from Liaojiashan, Yuexi County, Sichuan]. Kaogu 考古 [Archaeology] 5:476.

Pirazzoli-T'Serstevens, Michèle

1974 La civilisation du royaume de Dian à l'époque Han: D'après le matériel exhumé à Shizhai shan, Yunnan [The civilization of the kingdom of Dian during the Han period: According to the material excavated at Shizhai shan, Yunnan]. Paris: École française d'Extrême-Orient.

PSARRAS, SOPHIA-KARIN

2015 Han Material Culture: An Archaeological Analysis and Vessel Typology. Cambridge: Cambridge University Press.

Reimer, Paula, Edouard Bard, Alex Bayliss, J. Warren Beck, Paul G. Blackwell, Christopher Bronk Ramsey, Caitlin E. Buck, Hai Cheng, R. Lawrence Edwards, Michael Friedrich, Pieter M. Grootes, Thomas P. Guilderson, Haflidi Haflidason, Irka Hajdas, Christine Hatté, Timothy J. Heaton, Dirk L. Hoffmann, Alan G. Hogg, Konrad A. Hughen, K. Felix Kaiser, Bernd Kromer, Sturt W. Manning, Mu Niu, Ron W. Reimer, David A. Richards, E. Marian Scott, John R. Southon, Richard A. Staff, Christian S. M. Turney, and Johannes van der PLicht

2013 IntCal13 and Marine13 radiocarbon age calibration curves 050,000 years cal BP. Radiocarbon 55(4) : 1869-1887.

SACKetT, JAMES R.

1977 The meaning of style in archaeology: A general model. American Antiquity 42(3):369-380.

SHI JINSONG 施勁松

1999 Sichuan Wenchuanxian Zhaodiancun faxian de shiguanzang 四川文川縣昭店村發現的石棺葬 [Stone-cist graves discovered at Zhaodiancun, Wenchuan County, Sichuan]. Kaogu 考古 [Archaeology] 7:84-85.

Sichuan Daxue Zhongguo Zangxue Yanjiusuo 四川大學中國藏學咴究所, Sichuan Daxue KAOGUXI 四川大學考古系, AND XIZANG ZiZHIQU WENwUJU 西藏自治區文物局

2007 Xizang Ali diqu Dingdong juzhu yizhi fajue jianbao 西藏阿里丁東居住遺址發掘簡報 [Preliminary excavation report of the Dingdong living quarters in the Ali area of Tibet]. Kaogu 考古 [Archaeology] 11:36-46.

SichuAN LiangShan Yizu Zizhizhou Bowuguan 四川涼山彞族自治州博物館 AND SichuAN YANYUANXIAN WENHUAGUAN 四川鹽源縣文化館

1984 Sichuan Yanyuanxian Jiaodingshan faxian xinshiqi shidai yizhi 四川鹽源縣轎頂山發現新石器 時代遺址 [Neolithic sites discovered at Jiaodingshan, Yanyuan County, Sichuan]. Kaogu 考古 [Archaeology] 9:849-850. 
Sichuansheng Jinshajiang Dukou Xichang duan 四川省金沙江渡口西昌段 And Anninghe Liuyu LiANHE KAOGU DiAOCHADUI 安寧河流域聯合考古調查隊

1976 Xichang Bahe Baozi dashimu fajue jianbao 西昌壩河堡子大石墓發掘簡報 [Preliminary excavation report of the megalithic graves of Xichang Bahe Baozi]. Kaogu 考古 [Archaeology] $5: 326-330$.

Sichuansheng Wenguanhui 四川省文管會 And Maowenxian Wenhuaguan 茂汶縣文化館

1983 Sichuan Maowen Qiangzu Zizhixian shiguanzang fajue baogao 四川茂汶美族自治縣石棺葬 發掘報告 [Excavation report of the stone-cist graves of Sichuan Maowen Qiang Ethnic Minority Autonomous County]. Wenwu ziliao congkan 交物資料叢刊 [Cultural relics journal] $7: 34-55$

Sichuansheng Wenwu Guanli Weiyuanhui 四川省交物管理委員會, YA'An Diqu Wenguansuo 雅安 地區文管所, AND BAOXINGXIAN WENHUAGUAN 寶興縣文化館

1999 Sichuan Baoxing Hantanshan Zhanguo tukeng ji shimu fajue baogao 四川寶興漢塔山戰國 土坑积石墓發掘報告 [Excavation report on the Warring-States earth-pit and stone graves of Baoxing Hantanshan, Sichuan]. Kaogu xuebao 考古學報 [Acta archaeologica sinica] 3:337366.

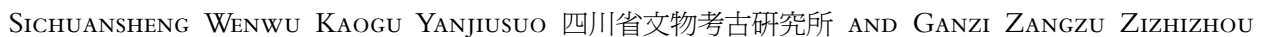
WeNHUAJU 甘孜藏族自治州文化局

1998 Danbaxian Zhongluxiang Han'e yizhi fajue jianbao 丹巴縣中路鄉罕额遺址發掘簡報 [Preliminary excavation report of Han'e site, Zhonglu Township, Danba County], in Sichuan kaogu baogaoji 四川考古報告集 [Sichuan archaeological reports]: 59-77, ed. Sichuansheng Wenwu Kaogu Yanjiusuo 四川省文物考古硏究所. Bejing: Kexue Chubanshe 科學 出版社.

Sichuansheng Wenwu Kaogu Yanjiuyuan 四川省文物考古㸴究院, Liangshan Yizu Zizhizhou BOWUGUAN 涼山彞族自治州博物館, AND XICHANGSHI WENWU GUANLISUO 西昌市交物管理所

2006a Anninghe liuyu dashimu 安寧河流域大石墓 [The megalithic graves of the Anning River Valley]. Beijing: Kexue Chubanshe 科學出版社.

20066 Liangshanzhou Xichangshi Maliucun huikeng qingli jianbao 凉山州西昌市麻柳村灰坑清理 簡報 [Preliminary excavation report of the object pit of Maliucun, Xichang City, Liangshan Prefecture]. Sichuan wenwu 四川文物 [Sichuan cultural relics] 1:11-12.

2006 c Liangshanzhou Xichangshi Qimugou yizhi shijue jianbao 涼山州西昌市棲木溝遺址試掘簡報 [Preliminary report on test excavations at Qimugou site, Xichang City, Liangshan Prefecture]. Sichuan wenwu 四川文物 [Sichuan cultural relics] 1:13-20.

2006d Sichuan Xichang Wanao, Dechang Arong dashimu 四川西昌窪堖、德昌阿榮大石墓 [The megalithic graves of Xichang Wanao and Dechang Arong, Sichuan]. Wenwu 文物 [Culture relics] $2: 10-20$.

2006e Liangshanzhou Xichangshi Dongping yizhi dierci fajue jianbao 涼山州西昌市東平遺志 第二次發掘簡報 [Preliminary report of the first exacavation conducted at Dongping site, Xichang City, Liangshan Prefecture]. Sichuan wenwu 四川文物 [Sichuan cultural relics] 1:2126.

Sichuansheng Wenwu Kaogu Yanjiusuo 四川省交物考古砰究所, Ya'Anshi Wenwu GunLisuo 雅安 市文物管理所, AND BAOXINGXIAN WENWU GUANLISUO 寶興縣文物管理所

2003 Sichuan Baoxing Qiaoqi Shuidianzhan Yanmo diqu kaogu fajue baogao 四川寶興硗碛水電站 淹没地區考古發掘報告 [Excavation report of Baoxing Qiaoqi Hyrdopower Station, Yanmo area, Sichuan]. Sichuan wenwu 四川文物 [Sichuan cultural relics] 5:8-9.

Sichuansheng Wenwu Kaogu Yanjiuyuan 四川省文物考古㸴究院 And Liangshan Yizu Zizhizhou BOWUGUAN 涼山蕬族自治州博物館

2006 Liangshanzhou Dechangxian Wangjiatian yizhi fajue jianbao 涼山州德昌縣王家田遺址發掘 簡報 [Preliminary excavation report of Wangiiatian site, Dechang County, Liangshan Prefecture]. Sichuan wenwu 四川文物 [Sichuan cultural relics] 1:3-10.

2007 Sichuan Dechangxian Maojiakan xinshiqi shidai yizhi fajue jianbao 四川德昌縣毛傢坎 新時期四代遺址發掘簡報 [Preliminary excavation report of the Neolithic site of Maojiakan, Dechang County, Sichuan]. Sichuan wenwu 四川文物 [Sichuan cultural relics] 1: $3-14$.

SichuANSheng Wenwu KaOgu YanjiUYuan 四川省文物考古㸴究院, Liangshan Yizu Zizhizhou Bowuguan 涼山彝族自治州博物館, AND HuILIXIAN Wenwu GuANLisuo 會理縣文物管理所

2009 Sichuan Huilicheng heliuyu kaogu diaocha baogao 四川會理城河流域考古調查報告 [Report on the archaeological survey of the Heliu River Valley, Sichuan]. Sichuan wenwu 四川交物 [Sichuan cultural relics] 4:15-22. 
Sichuansheng Wenwu KaOgu Yanjiuyuan 四川省文物考古㸴究院, Liangshan Yizu Zizhizhou BOWUGUAN 涼山彞族自治州博物館, AND MULIXIAN WENWU GUANLISUO 木里縣文物管理所

2012 Sichuan Mulixian Waliwacun kaogu diaocha shijue jianbao 四川木里縣考古調查實掘簡報 娃日瓦村 [Preliminary report of a survey and test excavations conducted at Wariwa Village, Muli County, Sichuan. Sichuan wenwu 四川文物 [Sichuan cultural relics] 6:3-10.

SMith, ADAM 亞當·史密斯

2001 Sichuan, Dian xibei, Zangdong diqu shiguanzang wenhua yanjiu 川西、槇西北、藏東地區 石棺葬文化㸴究 [Research on the stone-cist grave culture of Sichuan, Northwest Yunnan, and eastern Tibet]. Master's thesis. Kaogu Wenwu Baoyuan 考古文物博院, Peking University 北京大學, Beijing.

SONG ZHIMIN 宋治民

1991 Sichuan xibu shiguanzang he dashimu de jige wenti 四川西部石棺葬和大石墓的幾個問題 [Some questions on the stone-cist and megalithic graves of western Sichuan]. Kaogu 考古 [Archaeology] 5:225-235.

Sun Hua 孫華

2000 Sichuan pendi de qingtong shidai 四川盆地青銅時代 [The Bronze Age of the Sichuan Basin]. Beijing: Kexue Chubanshe 科學出版社.

TANG XIANG 唐翔

1992 Huilicheng heliuyu de gudai wenhua yicun 會理城河流域的古代文化遺存 [Ancient cultural remains in the Cheng River Valley in Huili]. Sichuan wenwu 四川[文物 [Sichuan cultural relics] $4: 14-18$

1993 Huili faxian yibing qingtongjian 會理發現一柄青銅劍 [A bronze sword discovered in Huili]. Sichuan wenwu 四川文物 [Sichuan cultural relics] 4:44.

1996 Huili xinjin shoucang de jijian qingtongqi 會理新近收藏的幾件青銅器 [A few bronzes recently collected in Huili]. Sichuan wenwu 四川[文物 [Sichuan cultural relics] 3:69-70.

1998 Huili xinjin shouzang de jijian qingtongqi 會理新近收藏的幾件青銅器 [Several bronze objects recently collected in Huili]. Sichuan wenwu 四川[文物 [Sichuan cultural relics] 3:16-18.

1999 Huili qingtong wenhua zongshu 會理青銅文化綜述 [Summary of the bronze-age cultures of Huli]. Sichuan wenwu 四川文物 [Sichuan cultural relics] 4:51-57.

TAO MingKUAN 陶鳴寬 AND ZHAODIAN ZENGZHI 趙殿增執

1981 Sichuan Huilixian faxian Washitian yizhi 四川會理縣發現瓦石田遺址 [Washitian site discovered in Huili County, Sichuan]. Wenwu ziliao congkan 文物資料叢刊 [Cultural relics journal] $5: 205-206$.

TONG ENZHENG 童恩正

1990 Shilun woguo cong dongbei zhi xinan de biandi banyuexing wenhua chuanliudai 試論我國從 東北至西南的遍地牛月形傳播帶 [Discussing the crescent-shaped cultural exchange belt stretching from northeast to southwest China], in Zhongguo Xinan minzu kaogu lunwenji 中國 西南民族考古論文集 [Essay collection on the ethnology and archaeology of southwest China]: 252-278, ed. Tong Enzheng 童恩正. Beijing: Wenwu Chubanshe 文物出版社.

WANG HeNGJIE 王恆傑

1979 Sichuan Liangshan Yizu Zizhizhou Xidexian de xin shiqi shidai yizhi 四川涼山粼族自治州 喜德縣的新石器時代遺址 [Neolithic sites of Xide County, Liangshan Yi Autonomous Prefecture, Sichuan]. Kaogu 考古 [Archaeology] 1:95-96.

XI XUEZHONG 舄學鍾

1991 Yongsheng Jinguan Longze qingtongqi leixing ji zushu 永勝金管龍澤青銅器類型及族屬 [Typology and ethnic affiliation of the Yongsheng Linguan Longze bronzes], in Yunnan qingtong wenhua lunji 雲南青銅文化論及 [Essay collection on the Yunnan bronze-age culture]: 244-261, ed. Yunnansheng Bowuguan 雲南省博物館. Kunming: Yunnan Renmin Chubanshe 雲南人民出版社.

Xichang DiQu Bowuguan 西昌地區博物館

1978a Luguhu chutu wenwu diaochaji 瀘沽湖畔出土文物調查記 [Survey of cultural relics excavated around Lake Lugu]. Liangshan Yizu nulizhi yanjiu 涼山彞族奴隸制砰究 [Research on the Liangshan Yi Slave-Society] 1:88-92.

1978b Dechangxian Wuyi Gongshe Guoyuan Dadui gu muzang qingli fajue jianbao 德昌縣五一公社 果園大榢古墓葬清理發掘簡報 [Preliminary report on the excavation of Wuyi Gongshe Guoyuan Dadui cemetery, Dechang County]. Liangshan Yizu nulizhi yanjiu 涼山彞族奴隸制 硏究 [Research on the Liangshan Yi Slave-Society] 2:81-84.

1978c Xichang Hexi dashimuqun 西昌河西大石墓群 [The Xichang Hexi megalithic-grave group]. Kaogu 考古 [Archaeology] 2:91-96. 
1978d Xichangxian Xijiao Gongshe yidadui diyihao mu qingli jianbao 西昌河西大石墓群 [Preliminary report on investigations into Xijiao Gongshe grave 1, Xichang County]. Liangshan Yizu nulizhi yanjiu 涼山彞族奴隸制㗏究 [Research on the Liangshan Yi Slave-Society] 2:5964.

Xichang Diqu Bowuguan 西昌地區博物館, Sichuansheng Bowuguan 四川省博物館, Sichuan Daxue LishiXi 四川大學歷史係, AND XichangXian WenhuAgUan 西昌縣文化館

1978 Xichang Bahe Baozi dashimu di'erci fajue jianbao 西昌壩河堡子大石墓第二次發掘簡報 [Preliminary report of the second excavation of the Xichang Bahe Baozi megalithic graves]. Kaogu 考古 [Archaeology] 2:86-90.

Xichangshi Wenwu Guanlisuo 西昌市文物管理所

1998 Sichuan Xichangshi Henglanshan xinshiqishidai yizhi diaocha 四川西昌市橫欄山新石器時代 遺址調查 [Survey of the Neolithic site of Henglanshan, Xichang City, Sichuan]. Kaogu 考古 [Archaeology] 2:5-9.

Xichangshi Wenwu Guanlisuo 西昌市文物管理所, Sichuansheng Wenwu Kaogu Yanjiusuo 四川 省文物考古研究所, AND LiANGSHAN YizU ZizHIZHOU BOWUGUAN 涼山粼族自治州博物館

2004 Sichuan Xichangshi Jingjiu Dayangdui yizhi fajue 四川西昌市經久大洋堆遺址發掘 [Excavations at Jingjiu Dayangdui site, Xichang City, Sichuan]. Kaogu 考古 [Archaeology] 10:2335 .

XIE Hui 謝輝 AND JiAng Zhanghua 江章華

2002 Minjiang shangyou de shiguanmu 岷江上游的石棺墓 [The stone-cist graves of the upper Min River]. Sichuan wenwu 四川文物 [Sichuan cultural relics] 1:9-15.

Xizang Zizhiqu Wenwu Guanli Weiyuanhui 西藏自治區文物管理委員會, And Sichuan Daxue LishiXi 四川大學歷史係

1985 Changdu Karuo 昌都卡若, Kaoguxue zhuankan 考古學專刊 [Monographs of Chinese Archaeology] 29. Beijing: Wenwu Chubanshe 文物出版社.

Xu Xueshu 徐學書

1999 Guanyu Dian wenhua he Dianxi qingtong wenhua niandai de zai tanlun 關於澛文化和澛西 青銅文化年代的再探論 [A renewed discussion of the Dian Culture and the date of the western Yunnan bronze-age culture]. Kaogu 考古 [Archaeology] 5:75-84.

YA'AN DIQU WENWU ZHIBIAN WeIHUI 雅安地區文物質變委會

1992 Ya'an diqu wenwuzhi 雅安地區文物質 [Annals of the cultural relics of Ya'an]. Chengdu: Bashu Chubanshe 巴蜀出版社.

YANG FAN 楊帆, WAN YANG 万揚, AND Hu ChangCheng 胡長城 (EDS.)

2009 Yunnan kaogu: 1979-2009 雲南考古：1979-2009 [Yunnan archaeology: 1979-2009]. Kunming: Yunnan Renmin Chubanshe 雲南人民出版社.

YANG ZHEFENG 楊哲峰

2001 Jin ershiliu nian lai xinandiqu “dahimu' de yanjiu zongshu 近二十六年來西南地區 “大石墓” 的 研究綜 [Summary of research on “megalithic graves” during the last sixty years]. Zhongguoshi yanjiu dongtai 中國史㸴究動態 [Research trends in Chinese history] 4:17-20.

Yao, Alice

2008 Culture contact and social change along China's ancient southwestern frontier, 900 B.C.100 A.D. Ph.D. diss. Department of Antropology, University of Michigan, Ann Arbor.

2010 Recent developments in the archaeology of southwestern China. Journal of Archaeological Research 18:203-239.

YUNNANSHENG BowUGUAN 雲南省博物館

1977 Yuanmou Dadunzi xinshiqishidai yizhi 元謀大墩子新石器時代遺址 [The Neolithic site of Yuanmou Dadunzi]. Kaogu xuebao 考古學報 [Acta archaeologica sinica] 1:43-72.

1985 Yunnan Yongren Caiyuanzi xinshiqishidai yizhi diaocha 雲南永仁荣園子新時期時代遺址調查 [Survey of the Neolithic site of Yongren Caiyuanzi, Yunnan]. Kaogu 考古 [Archaeology] 12:1039-1041.

1995 Yunnan Jianchuan Haimenkou qingtong shidai zaoqi yizhi 雲南劍川海門口青銅時代早期遺址 [The early bronze-age site of Jianchuan Haimenkou, Yunnan]. Kaogu 考古 [Archaeology] 9:775-787.

YunNANSHENG BOWUGUAN CHOUBEICHU 雲南省博物館籌備処

1958 Jianchuan Haimenkou gu wenhua yizhi qingli jianbao 劍川海門口古文化遺址清理簡報 [Preliminary report of investigations into the ancient culture of Jianchuan Haimenkou]. Kaogu tongxun 考古通訊 [Archaeological communications] 6:5-12. 
Yunnansheng Bowuguan Wenwu Gongzuodui 雲南省博物館文物工作隊

1975 Yunnan Deqin Yongzhi faxian de gu muzang 雲南德欽永芝發現的古墓葬 [The ancient graves discovered at Yunnan Deqin Yongzhi]. Kaogu 考古 [Archaeology] 4:244-248.

1983a Yunnan Deqinxian Nagu shiguanmu 雲南德欽縣納古石棺墓 [Yunnan Deqin County Nagu stone-cist graves]. Kaogu 考古 [Archaeology] 3:220-225.

19836 Yunnan Ninglangxian Daxingzhen gumuzang 雲南寧蒗縣大興鎭古墓葬 [Yunnan Ninglang County Daxingzhen ancient graves]. Kaogu 考古 [Archaeology] 3:226-232.

YunNANSHENG WeNWU GONGZUODUI 雲南省文物工作隊

1983 Chuxiong Wanjiaba gumuqun fajue baogao 楚雄万傢垻古墓群發掘報告 [Excavation report of the Chuxiong Wanjiaba ancient cemetery]. Kaogu xuebao 考古學報 [Acta archaeologica sinica] $3: 347-382$.

YUNNANSHENG WenwU KAOGU YANJIUSUO 雲南省文物考古㸴究所

2005 Yunnan Changning Fenlinggang qingtong shidai mudi 雲南昌寧墳嶺崗青銅時代墓地 [The bronze-age site of Changning Fenlinggang, Yunnan]. Wenwu 文物 [Cultural relics] 8:4-20, 70 .

YunNansheng Wenwu KaOgu Yanjiusuo 雲南省文物考古研究所, Dalishi Bowuguan 大理市博物館, Dalishi Wenwu Guanlisuo 大理市文物管理所, AND Dalizhou Wenwu GuAnlisuo 大理州交物 管理所

2009 Yunnan Dalishi Haidong Yinsuodao yizhi fajue jianbao 雲南大理市海東銀梭島遺址發掘簡報 [Preliminary excavation report of Haidong Yinsuodao site, Dali City, Yunnan]. Kaogu 考古 [Archaeology] 8:23-41.

Yunnansheng Wenwu KaOgu Yanjiusuo 雲南省文物考古研究所, Dalizhou Wenwu Guanlisuo 大理州文物管理所, AND JIANCHUANXIAN WENWU GUANLISUO 劍川縣文物管理所

2009 Yunnan Jianchuanxian Haimenkou yizhi 雲南劍川縣還門口遺址 [Haimenkou site, Jianchuan County, Yunnan]. Kaogu 考古 [Archaeology] 7:18-23.

YunNansheng Wenwu KaOgu Yanjiusuo 雲南省文物考古砗究所, Dalizhou Wenwu Guanlisuo 大理州文物管理所, AND YONGPINGXIAN WENWU GUANLISUO 永平縣文物管理所

2002 Yunnan Yongping Xinguang yizhi fajue baogao 雲南永平新光遺址發掘報告 [Excavation report of Yongping Xinguang site, Yunnan]. Kaogu xuebao 考古學報 [Acta archaeologica sinica] 2:203-234.

Yunnansheng Wenwu KaOgu Yanjiusuo 雲南省文物考古硏究所, Kunmingshi Bowuguan 昆明市 博物館, AND KunMingshi GUANDUQU Bowuguan 昆明市官渡區博物館

2005 Kunming Yangfutou mudi 昆明羊甫頭墓地 [Kunming Yangfutu cemetery], 4 vols. Beijing: Kexue Chubanshe 科學出版社.

YunNansheng Wenwu KaOgu Yanjiusuo 雲南省文物考古研究所, ZhaOtongShi Wenwu GuAnlisuo 昭通市文物管理所, AND LUDIANXIAN WENWU GUANLISUO 魯甸縣文物管理所

2009 Yunnan Ludianxian Yeshishan yizhi fajue jianbao 雲南魯甸縣野石山遺址發掘簡報 [Preliminary excavation report of Ludian Yeshishan site, Yunnan]. Kaogu 考古 [Archaeology] 8:4253.

Yunnansheng Wenwu Kaogu Yanjiusuo 雲南省文物考古㸴究所, Zhongguo Shehui Kexueyuan KAOGU YANJIUSUO YUNNAN GONGZUODUI 中國社會科學院考古砰究所雲南工作隊, CHENGDUSHI WenWu KaOgu YanjIUSUO 成都市文物考古研究所, ChuxiongzhOU BOwUGUAN 楚雄州博物館, AND YongRENXIAN WENHUAGUAN 永仁縣文化館

2003 Yunnan Yongren Caiyuanzi, Mopandi yizhi 2001 nian fajue baogao 雲南永仁荣園子、磨盤地 遺址2001年發掘報告 [Report of the 2001 excavations at Yunnan Yongren Caiyuanzi and Mopandi sites]. Kaogu xuebao 考古學報 [Acta archaeologica sinica] 3:263-295.

ZHAO DIANZENG 趙殿增

1981 Shilun Xichang Lizhou yizhi ji qi yu zhouwei wenhua de guanxi 試論西昌禮州遺址及其與 周圍文化的關係 [Discussing the relationship between Xichang Lizhou site and surrounding cultures]. Liangshan Yizu nulizhi yanjiu 涼山彞族奴隸制咑究 [Research on the Liangshan Yi Slave-Society] $1: 81-85$.

Zhongguo Gudai TongGu YanjiU Xuehui 中國古代銅鼓砰究學會

1988 Zhongguo gudai tonggu 中國古代銅鼓 [Ancient bronze drums of China]. Beijing: Wenwu Chubanshe 文物出版社.

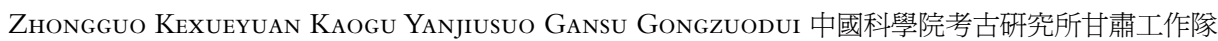

1975 Gansu Yongjing Qinwei Qijia wenhua mudi 甘肅永靖秦魏齊傢文化墓地 [The Qijia-Culture graves of Gansu Yongjing Qinwei]. Kaogu xuebao 考古學報 [Acta archaeologica sinica] 2:5796. 
Zhongguo Shehui Kexueyuan Kaogu Yanjiusuo 中國社會科學院考古砰究所

1980 Mancheng Hanmu fajue baoggao 滿城漢墓發覺報告 [Excavation report of the Mancheng Han graves]. Beijing: Wenwu Chubanshe 文物出版社.

ZhongGuo Wenwuju 中國文物侷

2009 Zhongguo wenwu dituji: Sichuan fence 中國文物地圖集・四川分冊 [China cultural atlas: Sichuan volume]. Beijing: Wenwu Chubanshe 交物出版社交物出版社.

ZhongGuo Wenwuju 中國文物侷 AND YunNANSheng WenhuATING 雲南省文化庭

2001 Zhongguo wenwu dituji: Yunnan fence 中國文物地圖集 : 雲南分冊 [China cultural atlas: Yunnan volume]. Kunming: Yunnan Kexue Chubanshe 雲南科技出版社.

ZHоu ZhiQING 周志清

20112009 Dechangxian Dongjiapo yizhi fajue jianbao [Report of the 2009 excavation of Dongjiapo site, Dechang County]. Nanfang Minzu Kaogu 南方民族考古 [Southern ethnology and archaeology] 7:495-526.

Zhou ZhiQing 周志清, TANg XIAng 唐翔, TANG Liang 唐亮, AND Su DehaO 素德浩

2010 Sichuan Huili Leijiashan yihaomu de fajue 四川會理雷家山一號墓的發掘 [Excavation of Sichuan Huili Leijiashan grave 1]. Kaogu 考古 [Archaeology] 4:14-27. 